Prepared in cooperation with the city of Independence, Missouri, Water Pollution Control Department

\title{
Water-Quality Trends of Urban Streams in Independence, Missouri, 2005-18
}

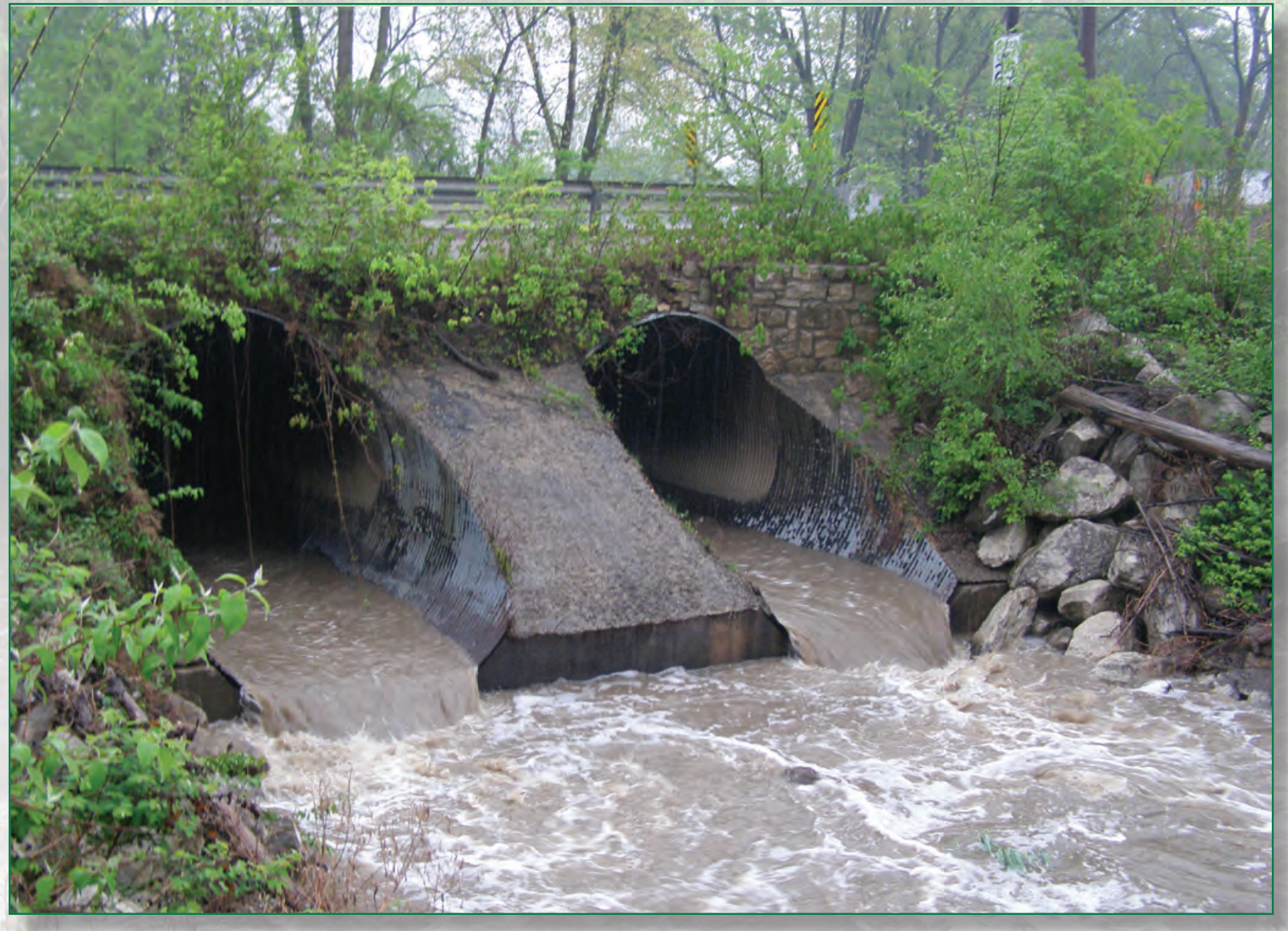

Scientific Investigations Report 2020-5130 
Cover. Outflow from a bridge culvert on Crackerneck Creek at Selsa Road in Independence, Missouri, after a storm event. 


\section{Water-Quality Trends of Urban Streams in Independence, Missouri, 2005-18}

By Miya N. Barr and Stephen J. Kalkhoff

Prepared in cooperation with the city of Independence, Missouri, Water Pollution Control Department

Scientific Investigations Report 2020-5130 


\title{
U.S. Department of the Interior \\ DAVID BERNHARDT, Secretary
}

\author{
U.S. Geological Survey \\ James F. Reilly II, Director
}

U.S. Geological Survey, Reston, Virginia: 2021

For more information on the USGS - the Federal source for science about the Earth, its natural and living resources, natural hazards, and the environment—visit https://www.usgs.gov or call 1-888-ASK-USGS.

For an overview of USGS information products, including maps, imagery, and publications, visit https://store.usgs.gov/.

Any use of trade, firm, or product names is for descriptive purposes only and does not imply endorsement by the U.S. Government.

Although this information product, for the most part, is in the public domain, it also may contain copyrighted materials as noted in the text. Permission to reproduce copyrighted items must be secured from the copyright owner.

Suggested citation:

Barr, M.N., and Kalkhoff, S.J., 2021, Water-quality trends of urban streams in Independence, Missouri, 2005-18:

U.S. Geological Survey Scientific Investigations Report 2020-5130, 57 p., https://doi.org/10.3133/sir20205130.

ISSN 2328-0328 (online) 


\section{Acknowledgments}

The authors would like to acknowledge the support and assistance received from staff at the city of Independence, Missouri, Department of Water Pollution Control during the study period. The knowledge and support of the staff were critical in the project development and evolution and in the investigation of the results.

The authors would like to acknowledge the U.S. Geological Survey staff who collected the physical samples and maintained equipment at the sites; whose tireless efforts and enthusiasm to capture storm events regardless of the day or hour, were fundamental for recording and documenting reliable science. The authors also would like to acknowledge all U.S. Geological Survey staff who assisted in the data compilation, interpretation, and production of this document and its findings; whose attention to detail and quality of data greatly benefit the text, illustrations, and tables presented in this report. 



\section{Contents}

Acknowledgments ……...................................................................................................................

Abstract

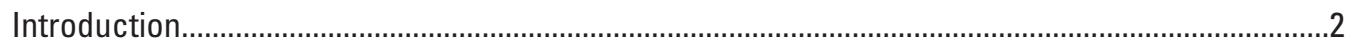

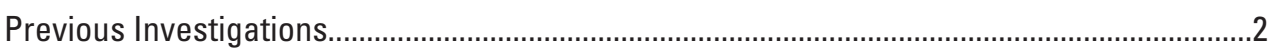

Storm and Wastewater Infrastructure Improvements ...........................................................

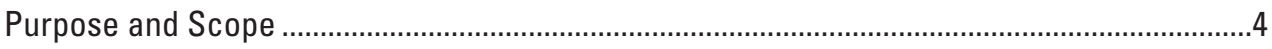

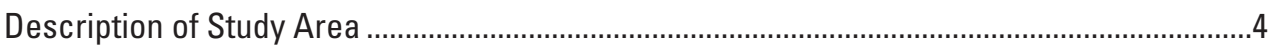

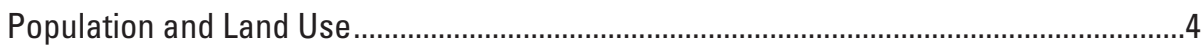

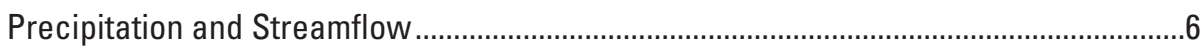

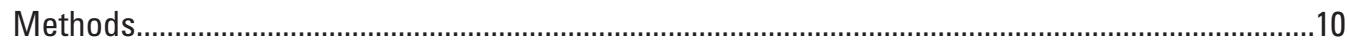

Water-Quality and Streamflow Data...................................................................................

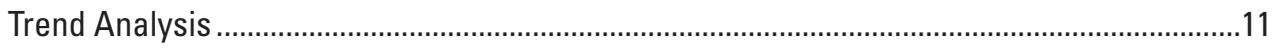

Analysis of Concentration Trends ..................................................................................11

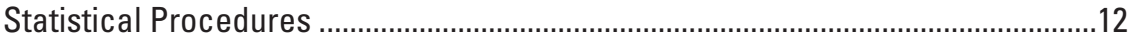

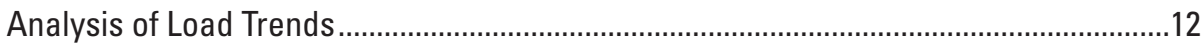

Comparisons of Model Estimates .........................................................................13

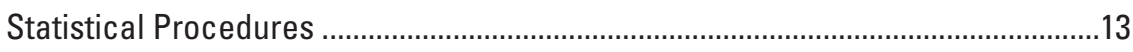

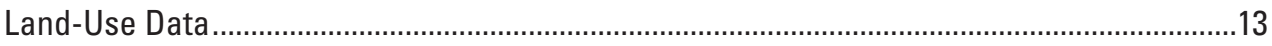

Water-Quality Trends in Concentrations and Loads .................................................................14

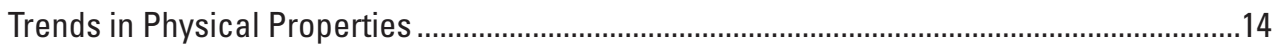

Trends in Nutrient Concentrations and Loads ................................................................14

Trends in Chloride and Total Dissolved Solids Concentrations and Loads ............................31

Trends in Fecal Indicator Bacteria Population Density........................................................32

Trends in Suspended-Sediment Concentrations and Loads ...................................................34

Observations in Concentrations by Land-Use and Water-Quality Criteria ...............................34

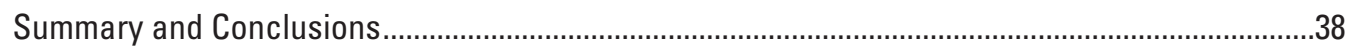

References Cited............................................................................................................

Appendix 1. Documentation of Concentration Trends for Urban Streams in
Independence, Missouri, Analyzed Using R-OWTREND ..................................................4

Appendix 2. Estimated Mean Annual Concentration, Load, and Yield for Selected Constituents in Urban Streams in Independence, Missouri .............................................55

Appendix 3. Annual Load Estimates Using Regression and Weighted Regressions on Time, Discharge, and Season-Kalman Filter Models .......................................................56

Appendix 4. Reclassification of the National Land Cover Database Land Cover in Urban Watersheds in Independence, Missouri ...............................................................................57

\section{Figures}

1. Map showing the Little Blue River watershed, sampling sites, study area location, and political boundaries for Independence, Missouri, and

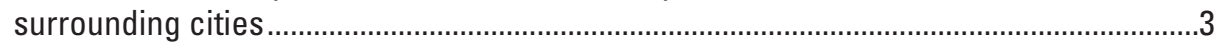

2. Graph showing population of Independence, Missouri, from 1930 through 2018 ............6

3. Map showing land use/land cover in the Little Blue River Watershed and adjacent watersheds within Independence, Missouri.. 
4. Graphs showing annual mean precipitation and air temperature in northwestern Missouri in relation to long-term trends, 2006-18.

5. Graphs showing streamflow conditions from 2006-18 in relation to long-term streamflow conditions in the Little Blue River near Lake City, Missouri 10

6. Graph showing analyzed versus Weighted Regressions on Time, Discharge, and Season-Kalman filter modeled concentrations for dissolved chloride at Little Blue River near Lake City, Missouri, 2004-17.

7. Location map and graphs showing sites with statistically significant trends in flow-weighted dissolved oxygen concentrations from 2006 through 2018

8. Location map and graphs showing sites with statistically significant trends in flow-weighted total nitrogen concentrations from 2006 through 2018

9. Location map and graphs showing sites with statistically significant trends in flow-weighted total organic nitrogen concentrations from 2006 through 2018

10. Location map and graphs showing sites with statistically significant trends in flow-weighted total ammonia plus organic nitrogen as nitrogen concentrations from 2006 through 2018

11. Location map and graphs showing sites with statistically significant trends in flow-weighted total phosphorus concentrations from 2006 through 2018. .26

12. Location map and graphs showing sites with statistically significant trends in dissolved ortho-phosphate as phosphorus concentrations from 2006 through 2018 ....27

13. Graphs showing significant trends in annual dissolved ammonia loads at the Little Blue River near Lake City, Missouri, 2006-18.

14. Location map and graphs showing sites with statistically significant trends in flow-weighted Escherichia coli bacteria densities from 2006 through 2018

15. Boxplots showing selected physical properties, nutrients, chloride, fecal indicator bacteria, and suspended-sediment concentrations at select Independence, Missouri, urban and northern Missouri agricultural sites and State of Missouri water-quality criteria, October 2005 through September 2018 36

\section{Tables}

1. Study site information for urban sites within Independence, Missouri .............................5

2. Land use in urban watersheds in Independence, Missouri...

3. Summary of trend results based on data collected during 2006-18 for select physical properties and chemical constituents at selected sites having data meeting trend model criteria

4. Summary of trend results based on a fixed period during 2010-17 for select physical properties and chemical constituents at selected sites having data meeting trend model criteria

5. Trends in loads for selected water-quality constituents transported in urban streams in Independence, Missouri.

6. Mean annual nitrogen load and yield at selected sites in the Little Blue River watershed, 2011-18

7. Mean annual loads in urban streams in Independence, Missouri, for two hydrologic periods 


\section{Conversion Factors}

International System of Units to U.S. customary units

\begin{tabular}{|c|c|c|}
\hline Multiply & By & To obtain \\
\hline \multicolumn{3}{|c|}{ Length } \\
\hline centimeter $(\mathrm{cm})$ & 0.3937 & inch (in.) \\
\hline millimeter (mm) & 0.03937 & inch (in.) \\
\hline meter $(\mathrm{m})$ & 3.281 & foot $(\mathrm{ft})$ \\
\hline kilometer $(\mathrm{km})$ & 0.6214 & mile (mi) \\
\hline kilometer $(\mathrm{km})$ & 0.5400 & mile, nautical (nmi) \\
\hline meter $(\mathrm{m})$ & 1.094 & yard (yd) \\
\hline \multicolumn{3}{|c|}{ Area } \\
\hline hectare (ha) & 2.471 & acre \\
\hline square kilometer $\left(\mathrm{km}^{2}\right)$ & 247.1 & acre \\
\hline hectare (ha) & 0.003861 & square mile $\left(\mathrm{mi}^{2}\right)$ \\
\hline square kilometer $\left(\mathrm{km}^{2}\right)$ & 0.3861 & square mile $\left(\mathrm{mi}^{2}\right)$ \\
\hline \multicolumn{3}{|c|}{ Volume } \\
\hline cubic meter $\left(\mathrm{m}^{3}\right)$ & 6.290 & barrel (petroleum, 1 barrel = 42 gal $)$ \\
\hline cubic meter $\left(\mathrm{m}^{3}\right)$ & 264.2 & gallon (gal) \\
\hline cubic meter $\left(\mathrm{m}^{3}\right)$ & 0.0002642 & million gallons (Mgal) \\
\hline cubic meter $\left(\mathrm{m}^{3}\right)$ & 35.31 & cubic foot $\left(\mathrm{ft}^{3}\right)$ \\
\hline cubic meter $\left(\mathrm{m}^{3}\right)$ & 1.308 & cubic yard $\left(\mathrm{yd}^{3}\right)$ \\
\hline cubic meter $\left(\mathrm{m}^{3}\right)$ & 0.0008107 & acre-foot (acre-ft) \\
\hline milliliter $(\mathrm{mL})$ & 0.033814 & fluid ounce (oz) \\
\hline milliliter $(\mathrm{mL})$ & 0.002113 & pint (pt) \\
\hline milliliter $(\mathrm{mL})$ & 0.001057 & quart (qt) \\
\hline milliliter $(\mathrm{mL})$ & 0.002642 & gallon (gal) \\
\hline \multicolumn{3}{|c|}{ Flow rate } \\
\hline cubic meter per second $\left(\mathrm{m}^{3} / \mathrm{s}\right)$ & 70.07 & acre-foot per day (acre-ft/d) \\
\hline cubic meter per second $\left(\mathrm{m}^{3 / \mathrm{s}}\right)$ & 35.31 & cubic foot per second $(\mathrm{ft} 3 / \mathrm{s})$ \\
\hline millimeter per year $(\mathrm{mm} / \mathrm{yr})$ & 0.03937 & inch per year (in/yr) \\
\hline \multicolumn{3}{|c|}{ Mass } \\
\hline kilogram (kg) & 2.205 & pound avoirdupois (lb) \\
\hline megagram $(\mathrm{Mg})$ & 2,205 & pound avoirdupois (lb) \\
\hline
\end{tabular}

Temperature in degrees Celsius $\left({ }^{\circ} \mathrm{C}\right)$ may be converted to degrees Fahrenheit $\left({ }^{\circ} \mathrm{F}\right)$ as

${ }^{\circ} \mathrm{F}=\left(1.8 \times{ }^{\circ} \mathrm{C}\right)+32$. 


\section{Supplemental Information}

Specific conductance is given in microsiemens per centimeter at 25 degrees Celsius $(\mu \mathrm{S} / \mathrm{cm}$ at $\left.25^{\circ} \mathrm{C}\right)$.

Concentrations of chemical constituents in water are given in either milligrams per liter (mg/L) or micrograms per liter $(\mu \mathrm{g} / \mathrm{L})$.

A water year is the 12-month period from 0ctober 1 through September 30 and designated by the calendar year in which it ends (water year 2019 is the period beginning October 1, 2018, and ending September 30, 2019).

\section{Abbreviations}

$\mathrm{CFU} / 100 \mathrm{~mL}$ colony forming units per 100 milliliters

E. coli Escherichia coli

EPA U.S. Environmental Protection Agency

FIB fecal indicator bacteria

GIS geographic information system

LOADEST Load Estimator (a FORTRAN program for estimating constituent loads in streams and rivers)

MS4 municipal separate storm sewer system

NLCD National Land Cover Database

NURP Nationwide Urban Runoff Program

ortho-P dissolved orthophosphate as phosphorus

PARMA periodic autoregressive moving average

$p$-value probability value

SCR secondary contact recreation

SSC suspended-sediment concentration

SSL suspended-sediment load

TDS total dissolved solids

TN total nitrogen

TP total phosphorus

TON total organic nitrogen

USGS U.S. Geological Survey

WBC-B whole-body contact class B

WRTDS Weighted Regressions on Time, Discharge, and Season

WRTDS-K Weighted Regressions on Time, Discharge, and Season-Kalman filter 


\title{
Water-Quality Trends of Urban Streams in Independence, Missouri, 2005-18
}

\author{
By Miya N. Barr and Stephen J. Kalkhoff
}

\section{Abstract}

The U.S. Geological Survey and the city of Independence, Missouri, Water Pollution Control Department has studied the water quality and ecological condition of urban streams within Independence since 2005. Selected physical properties, nutrients, chloride, fecal indicator bacteria (Escherichia coli and total coliform), total dissolved solids, and suspended-sediment concentration data for base-flow and stormflow samples were used to document temporal trends in concentrations and flow-weighted concentrations; and annual loads were computed and investigated for selected nutrients, chloride, and suspended sediment. The six study sites included in this report are located on five urban streams: Rock Creek, a tributary in the city that drains to the Missouri River; three tributaries of the Little Blue River within the city (East Fork Little Blue River, Adair Creek, and Spring Branch Creek); and two sites on the main stem of the Little Blue River (one upstream from the city and one downstream from the three tributaries).

Many factors such as population, land use, and climate, and combinations of these factors contributed to the significant changes in the concentrations and transport of nutrients, chloride, fecal indicator bacteria, and suspended sediment in the urban streams within Independence. The population of Independence and the amount of developed land in the urban watersheds remained unchanged during the 2005-18 study. Differences were noted in precipitation and in streamflow during the study. Annual precipitation and streamflow were separated into two time periods within the study — period 1 (2006-10), having greater annual streamflow and precipitation, and period 2 (2011-18), having about 30 percent lower annual streamflow and less precipitation. Streamflow was an important factor in the transport of nitrogen, phosphorus, chloride, and suspended sediment from the urban watersheds. Changes in data collection methodology during the study period and improvements to the city stormwater and wastewater infrastructure also could have contributed to some of the trends. Between 2009 and 2015, more than 35 million dollars of improvements were made to stormwater and wastewater infrastructure within the city. These improvements, such as additional sewage overflow holding tanks, removal of septic tanks, and improved and expanded sanitary sewer lines and storm overflows, also could have affected the decreased nutrients and fecal indicator bacteria trends among the urban streams in the study area.

Models were used for analyzing streamflow-related variability in constituent concentrations and loads to determine if the water quality changed significantly during the study period. Trends in concentration data at four sites were analyzed using a statistical package called R-QWTREND and trends in load data were analyzed at six sites using a statistical package called Weighted Regressions on Time, Discharge, and Season-Kalman filter (WRTDS-K); both developed by the U.S. Geological Survey and publicly available for use.

Statistically significant trends in flow-weighted nutrient concentrations and loads generally were downward during the study period. The only nutrient compound with a statistically significant upward trend in flow-weighted concentration was dissolved orthophosphate as phosphorus at the Rock Creek site and the upstream site on the Little Blue River. A statistically significant downward trend in annual dissolved ammonia load was identified at the downstream Little Blue River site. A significant upward linear trend in annual orthophosphate as phosphorus load was identified on Adair Creek.

A statistically significant upward trend in dissolved chloride concentrations was identified at the downstream Little Blue River site. Road salt application near the site during the winter could have resulted in higher concentrated runoff during wet weather conditions. Annual chloride loads significantly decreased in Adair Creek and Spring Branch Creek. The mean annual chloride load transported in the drier (2011-18) period 2 was significantly less than during the wetter (2006-10) period 1, indicating that trends in precipitation runoff are an important factor in trends in annual transport of chloride.

Statistically significant downward trends in flowweighted fecal indicator bacteria Escherichia coli (E. coli) population densities were noted for Rock Creek and the downstream site on the Little Blue River. However, no trend was identified in E. coli population density at the upstream Little Blue River site. The downward trend in E. coli population density at the downstream site could be a result of decreased streamflow and precipitation over the study period, storage of fecal indicator bacteria in the Little Blue River streambed within the study area, die-off of fecal indicator bacteria during travel from upstream to downstream, changes in the sample 
collection methodology, improvements to the city's stormwater and wastewater infrastructures, or a combination of these factors.

The statistically significant downward trend in suspended-sediment concentration identified at the upstream Little Blue River site could be affected by the decreased streamflow and precipitation during the study period, by changes in sampling methods within the study period, and by the decrease in construction and urban land development upstream from the city.

No statistically significant change was indicated in the annual suspended-sediment load transported from Independence to the Little Blue River during the study period. More than one-half the suspended sediment transported in the Little Blue River originated in the watershed upstream from Independence.

The Little Blue River and many of its tributaries that drain Independence have been designated as recreational waters classified for whole-body contact class B and secondary contact recreation, and some have been listed as impaired for $E$. coli by the Missouri Department of Natural Resources from urban runoff and storm sewers. Observations were made among the available E. coli population density data for both Little Blue River sites to further understand water-quality conditions over the study period. Both Little Blue River sites had similar medians and geometric means for the recreational season (April through October) and during the full study period, both of which are greater than the regulatory population density for both recreational classes. The Little Blue River drainage area nearly doubles in size from the upstream to downstream site; therefore, the consistent geometric mean and median of $E$. coli population densities at the upstream and downstream Little Blue River sites could be primarily due to the larger volume of streamflow creating a dilution effect. Other possible factors could be storage of fecal indicator bacteria in stream bed sediments, die-off of fecal indicator bacteria during transport, improvements to the city's wastewater and stormwater infrastructure, changes to sampling methodology, or a combination of these factors. Specific sources of the E. coli are currently (2019) unknown.

\section{Introduction}

The U.S. Geological Survey (USGS) and the city of Independence, Missouri, Water Pollution Control Department, began a cooperative study in June 2005 to characterize and evaluate the water quality and ecological condition of urban streams within Independence (fig. 1). The quantities and sources of pollutants were characterized to better understand the processes that affect water quality and its effect on aquatic life in Independence streams. The data collected assisted the city of Independence in fulfilling its National Pollution Discharge Elimination System permit requirements for the municipal separate storm sewer system (MS4). An MS4 is a system of conveyances that include man-made channels, pipes, tunnels, and storm drains, as well as surface streets, catch basins, curbs, gutters, and ditches that discharge into waters of the United States (U.S. Environmental Protection Agency, 2018). The monitoring of an MS4 is mandated by Federal and State Government regulations. For Independence to meet the conditions for its MS4 permit and to design effective strategies to reduce contaminant discharges to streams, information about the source and nature of contaminants identified in receiving streams was initially needed. As a result of this study, a network of monitoring sites was installed and instrumented to measure streamflow and select waterquality constituents and to automatically collect stormwater samples. Collection of water-quality data in urban streams in Independence continued through 2018 resulting in a dataset that can be used to evaluate the progress of applied best management practices and to establish a baseline by which the effectiveness of current (2019) and future best management practices can be measured.

\section{Previous Investigations}

The U.S. Environmental Protection Agency (EPA) led the Nationwide Urban Runoff Program (NURP) research project between 1979 and 1983 (U.S. Environmental Protection Agency, 1983), and one of the study sites was on Rock Creek, an urban stream in Independence, Mo. (fig. 1). The NURP study concluded that urban runoff was the cause of much pollution nationwide, and the goals of the Clean Water Act would not be met if action was not taken (U.S. Environmental Protection Agency, 1983). During the initial phase (1991-92) of the National Pollution Discharge Elimination System permit process, the water quality of base flow and stormflow was evaluated in five urban streams within Independence (Schalk, 1994).

In June 2005, the USGS began to collect and analyze base-flow and stormflow samples from selected streams within the city limits of Independence. The objective of waterquality monitoring was to characterize and assess contaminant sources, concentrations, loads, and yields of various constituents from tributaries receiving inflow from within the MS4 boundary and to determine each constituent's contribution to the overall water quality and ecological condition of the Little Blue River (fig. 1). From June 2005 through December 2008, data were collected from four sampling sites (sites 1, 5, 6, and 8; fig. 1). The data consisted primarily of stormflow runoff samples with less frequent base-flow sampling and a small suite of selected constituents (Christensen and others, 2010). From 2009 through 2014, five sampling sites (sites 2, 3, 4, 7, and 9; fig. 1) were included with an increased number of baseflow samples and additional constituents to develop a more robust dataset. Loads were computed for selected constituents collected from the nine sites (Niesen and Christensen, 2015). Data collected from 2007 through 2011 were used to evaluate the ecological health of Independence streams (Christensen 


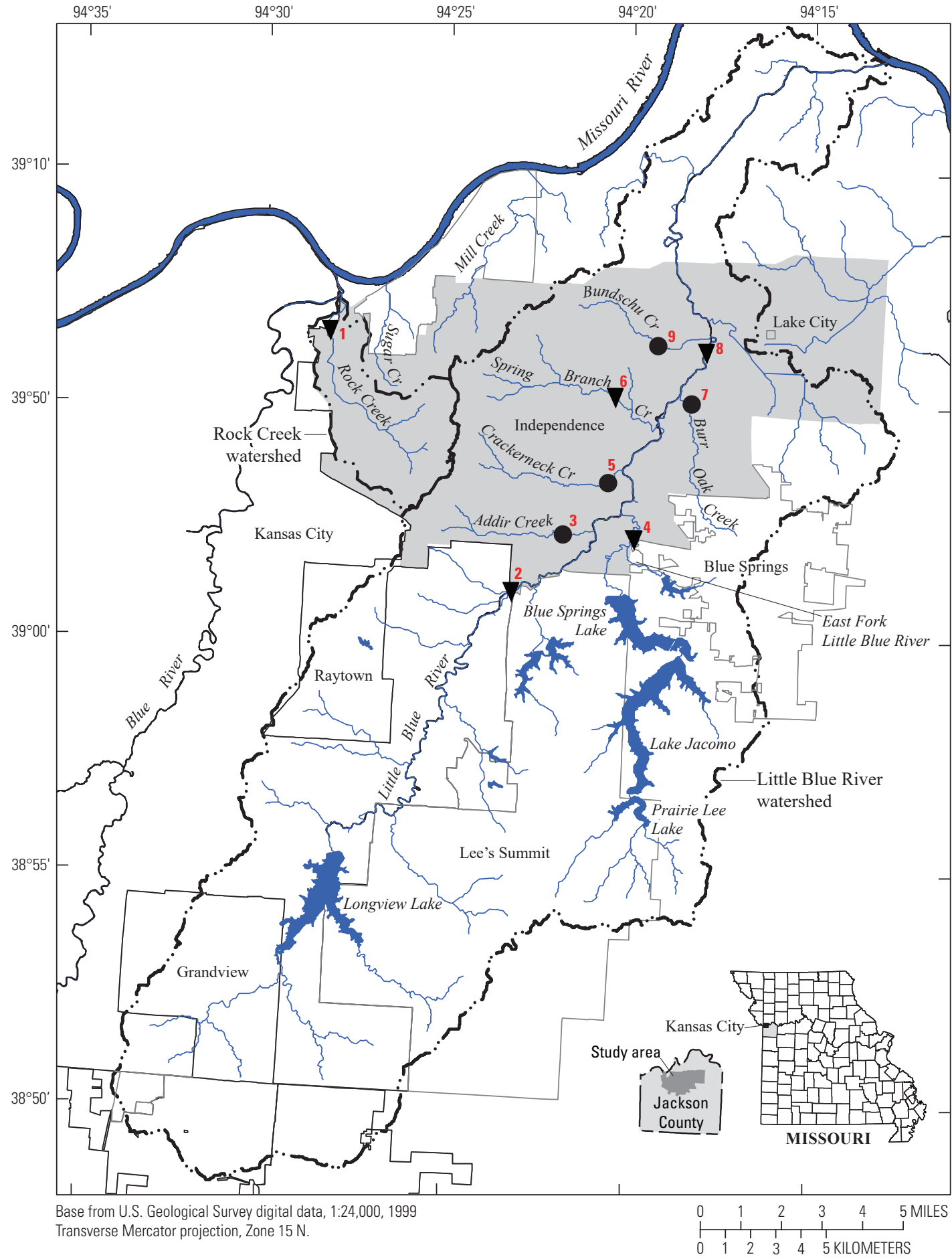

EXPLANATION

Study area and city boundary of Independence

1 Sampling site number (table 1)
Sampling site with U.S. Geological Survey streamgage

Sampling site, ungaged

Figure 1. The Little Blue River watershed, sampling sites, study area location, and political boundaries for Independence, Missouri, and surrounding cities. Modified from Niesen and Christensen (2015). 
and Krempa, 2013). Concentrations, loads, and yields of Escherichia coli (E. coli) and microbial source tracking from 2008 through 2015 have been used to examine potential sources of E. coli within the MS4 and sources entering and leaving the city through the Little Blue River (Bushon and others, 2017). Results indicated no statistically significant difference between $E$. coli loads entering the MS4 and E. coli loads leaving the MS4.

\section{Storm and Wastewater Infrastructure Improvements}

During 2009, the city of Independence signed a consent decree with the U.S. Department of Justice and the EPA to improve stormwater and wastewater infrastructures during a 5 -year period at an estimated cost of about $\$ 35$ million (U.S. Department of Justice, 2009). Major improvements were made to the Rock Creek Wastewater Treatment Plant. The improvements included upgraded pump stations and installation of two new holding tanks, each with 2.5-million-gallon capacity, increasing the plant's storage capacity to 10 million gallons. The increased storage capacity minimized the risk of untreated sanitary sewer overflow into streams during extreme weather or periods of increased sanitary use. Sanitary sewer lines in Rock Creek, Sugar Creek, and Mill Creek watersheds were upgraded, and sanitary lines in the Burr Oak Creek watershed area were expanded (fig. 1). At least 43 septic tanks were removed, and the properties were connected to sanitary sewer lines in the Bundschu Creek watershed (fig. 1). Improvements and additional sewer lines also were added to the Adair Creek watershed (fig. 1).

\section{Purpose and Scope}

The purpose of this report is to present trends in water quality in relation to changes in precipitation, streamflow, population, and land use in urban streams using data collected by USGS staff from 2005 through 2018 as part of an ongoing, cooperative study with the Independence Water Pollution Control Department. Selected physical properties, nutrients, chloride, fecal indicator bacteria (FIB; such as E. coli and total coliform), total dissolved solids (TDS), and suspendedsediment concentration (SSC) data for base-flow and stormflow samples were used to document temporal trends in concentrations and flow-weighted concentrations; annual loads were computed and investigated for selected nutrients, chloride, and suspended sediment. Concentration and annual-load trends presented are based on discrete surface water-quality data collected from January 2006 through December 2018. Annual loads are estimated from discrete water-quality data and daily streamflow data. The methods used to analyze trends and loads differ from previous investigations (Christensen and others, 2010; Niesen and Christensen, 2015) and are discussed in the "Methods" section of this report.

\section{Description of Study Area}

The city of Independence, Mo., is east of Kansas City in Jackson County (fig. 1). The sites within the study cover about 288 square kilometers $\left(\mathrm{km}^{2}\right)$ of total drainage area within the city limits of Independence (fig. 1; table 1).

About two-thirds of Independence is drained by the Little Blue River and its tributaries, and most of these streams flow generally northward to the Missouri River (fig. 1). Of the total drainage area of the Little Blue River at its confluence with the Missouri River (580 km²; Ellis, 2018), about $160 \mathrm{~km}^{2}$, or roughly 28 percent, is within Independence (fig. 1; table 1). The Little Blue River within Independence is monitored as part of the MS4 between the sites Little Blue River at Lee's Summit Road in Independence, Mo. (site 2) and Little Blue River near Lake City, Mo. (site 8; fig. 1). The largest tributary to the Little Blue River is the East Fork Little Blue River. Both the Little Blue River and East Fork Little Blue River have sizable parts of their drainage area upstream from Independence (fig. 1). The Little Blue River drains an area of $476 \mathrm{~km}^{2}$ (site 8) of which $254 \mathrm{~km}^{2}$ or 43 percent is upstream from Independence (fig. 1; table 1). The East Fork Little Blue River (site 4) drains an area of $89.1 \mathrm{~km}^{2}$, most of which is upstream of Independence (fig. 1; table 1). Adair Creek, Crackerneck Creek, and Spring Branch Creek are tributaries of the Little Blue River and drain the west-central part of Independence (fig. 1). Rock Creek drains northwest from Independence and flows north, discharging directly to the Missouri River (fig. 1).

Some of the streams in Independence have stream classifications designated by the State of Missouri (Missouri Department of Natural Resources, 2019a). The Little Blue River and East Fork Little Blue River are classified by the State of Missouri as Class P (perennial) streams suitable for whole-body contact class $\mathrm{B}$ (WBC-B) and secondary contact recreation (SCR). Burr Oak Creek is a Class-C stream, meaning the stream has perennial pools that may not flow during periods of drought and has designated uses including $\mathrm{WBC}-\mathrm{B}$ and SCR. The remaining streams in Independence are currently (2019) unclassified. Within Independence, the streams are mostly channelized. The reach of the Little Blue River is listed in the Missouri Code of State Regulations (10 CSR 20-7) as a metropolitan no discharge stream, meaning no municipal effluent can be discharged directly into the stream (Missouri Department of Natural Resources, 2019a).

\section{Population and Land Use}

The population of the city of Independence increased rapidly from 1940 through the 1960 s (fig. 2). The population increased from about 16,000 in 1940 to about 112,000 in 1970 . The population has been relatively constant since 1970 , increasing less than 1 percent per decade to about 117,000 in 2018 (U.S. Census Bureau, 2020). The number of households in Independence during 2014-18 was 48,166, and the population per square mile was about 581 people per square kilometer in 2010 (U.S. Census Bureau, 2020). 


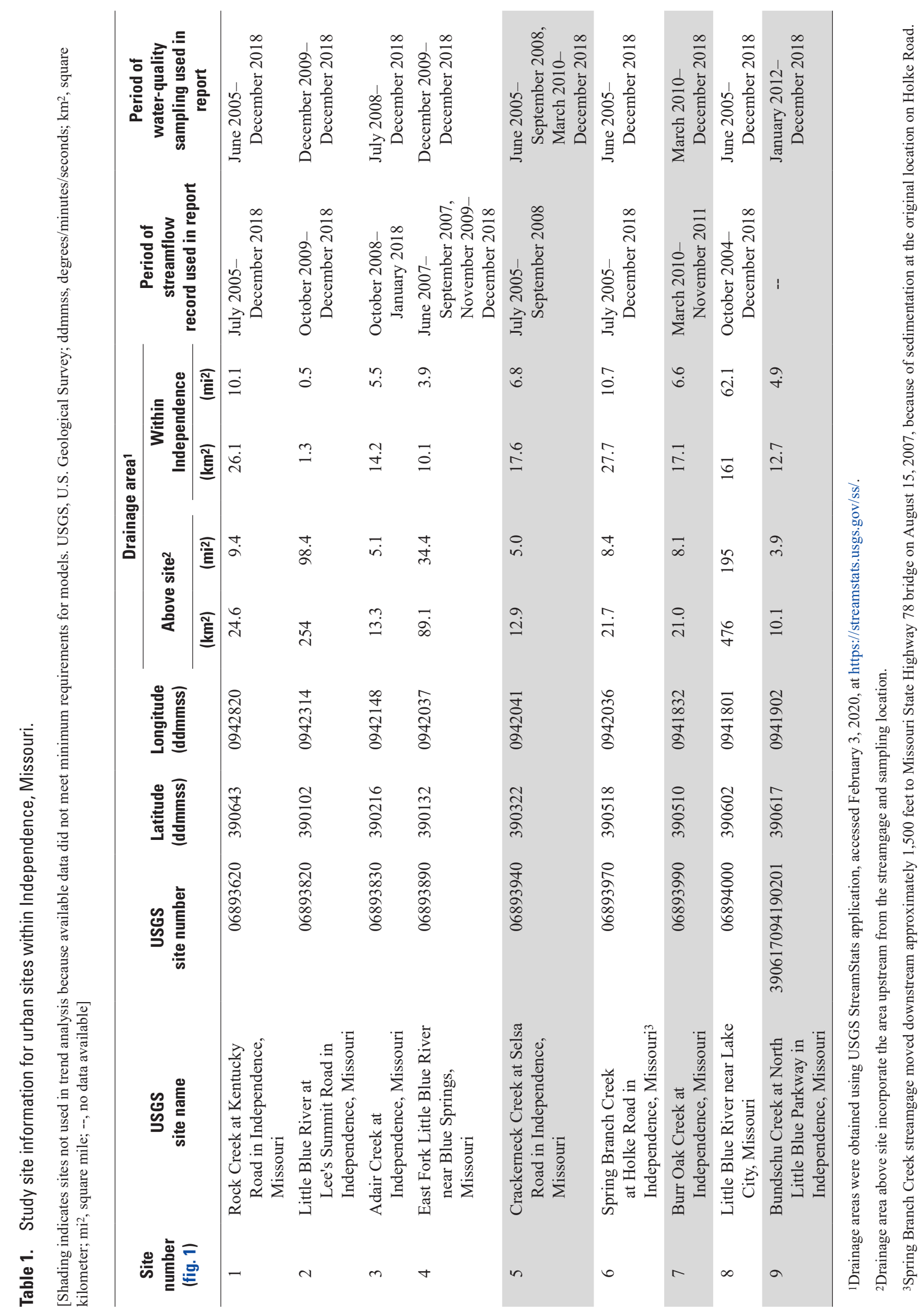




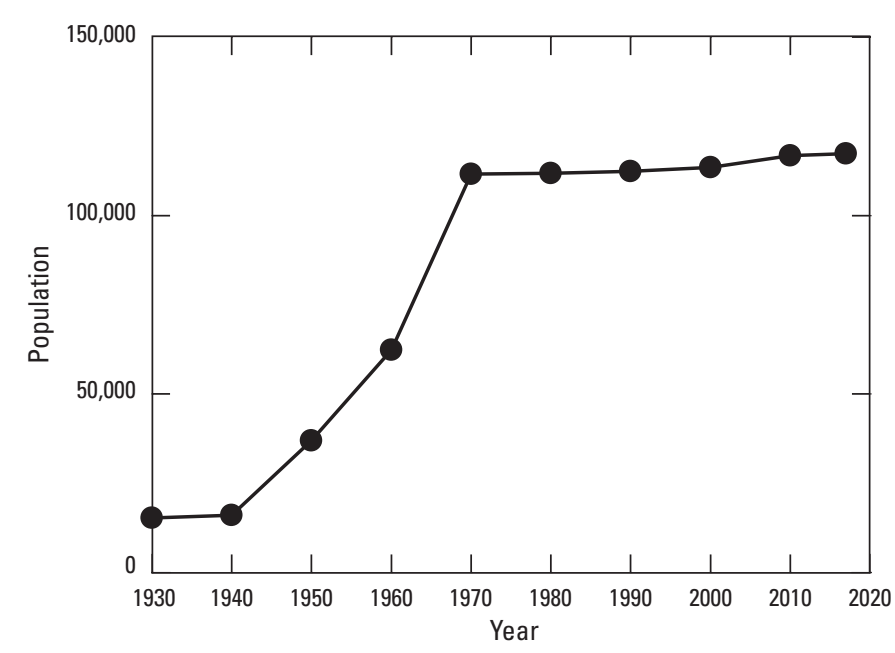

Figure 2. Population of Independence, Missouri, from 1930 through 2018. Data from U.S. Census Bureau (2020).

Land use of watersheds upstream from and draining Independence have been classified primarily as developed land and comprise about 46 to about 94 percent of the total area (table 2). Developed land types such as open space, low-, medium-, and high-intensity (table 2) refer to residential, commercial, and industrial uses and are classified based on percent imperviousness (Yang and others, 2018). Percentages of developed areas of watersheds draining the city range from about 70 to about 94 percent and have remained similar from 2006 to 2016 (table 2). The percentage of developed areas within Independence are greater than the percentage of developed area in watersheds upstream from Independence (table 2). The total percentage of developed areas in watersheds upstream from Independence were nearly equal to the total of all other identified land uses (grassland, forest, cultivated crops, open water, wetlands, and barren; table 2).

Undeveloped areas of Independence (grassland, forest, cultivated crops, open water, wetlands, and barren) cover a much smaller area than the developed areas (table 2). The western part of Independence is primarily urbanized, whereas the eastern and northern parts of the city are characterized by large tracts of undeveloped land, including grasslands, forests, and cultivated croplands, with some new residential construction on what had previously been vacant and agriculturalzoned land (fig. 3). The total percentage of undeveloped area in watersheds draining Independence range from about 6 to 27 percent and have remained similar from 2006 through 2016 (table 2).

Land use within the Little Blue River watershed upstream from and within Independence had minimal changes from 2006 through 2016. The largest land-use change within the entire watershed was a decrease in cultivated crops that was offset mainly by increases in forest, and low-, and medium-, intensity development (table 2). The percentage of each watershed upstream from Independence that was developed remained unchanged at about 50 percent for the Little Blue River and about 46 percent for the East Fork Little Blue River (table 2).

\section{Precipitation and Streamflow}

Since 1940, annual precipitation in northwestern Missouri (fig. 4) has ranged from 54 to 144 centimeters $(\mathrm{cm})$ (Midwestern Regional Climate Center, 2019). Although no long-term trend is indicated, annual precipitation (fig. 4) decreased from $105 \mathrm{~cm}$ in period $1(2006-10)$ to $93 \mathrm{~cm} / \mathrm{yr}$ in period 2 (2011-18). The 30-year (1981-2010) mean annual precipitation for northwestern Missouri is $99.4 \mathrm{~cm}$. During period 1 , mean annual precipitation was greater than the 30 -year mean, and during period 2, mean annual precipitation was less than the 30-year mean (Midwestern Regional Climate Center, 2019). During the study period (2006-18), the wettest year was 2008 followed by 2015, and the driest year was 2012 followed by 2006 (fig. 4). The 30-year mean annual precipitation for Independence is $110.9 \mathrm{~cm}$ (43.67 inches) (Midwestern Regional Climate Center, 2019).

Although precipitation values remained relatively constant (fig. 4), differences in the mean annual streamflow and annual low streamflow at the Little Blue River near Lake City, Mo. (site 8, streamgage 06894000) can be identified by observing the central tendency (LOESS smooth line) with time from 1949 through 2018 (fig. 5; U.S. Geological Survey, 2019). Mean annual streamflow (fig. 5) increased substantially during a period of rapid population growth (fig. 2) from the 1950 s through the 1970s, indicating that urbanization in Independence and upstream in the Little Blue River watershed affected the streamflow. Urbanization and its increase in impermeable surfaces and stormwater drainage potentially caused larger amounts of rainfall runoff to flow to rivers and streams. No wastewater treatment plants or discharge points from plants are along the reach of the Little Blue River, because this stream is designated as a no discharge stream (Missouri Department of Natural Resources, 2019a). Mean annual streamflow has remained constant during the period of minimal population increases from 1980 to 2018 (fig. 5).

Low flow in the Little Blue River also increased during the period of rapid population growth (figs. 2, 5). The annual 7 -day minimum streamflow increased from less than 0.1 cubic meter per second $\left(\mathrm{m}^{3} / \mathrm{s}\right)$ in the 1950 s to more than $0.4 \mathrm{~m}^{3} / \mathrm{s}$ in the 1970s (fig. 5). The substantial decrease in minimum flow during the 1980s (fig. 5) most likely resulted from completion of the large reservoirs on the upper Little Blue River and East Fork Little Blue River. The dams on the East Fork Little Blue River were completed in 1936 (Prairie Lee Lake [fig. 1]; Heimann, 1995) and 1986 (Blue Springs Lake [fig. 1]; Rouse, 2004), whereas the dam on the Little Blue River (Longview Lake [fig. 1]) was completed in 1985 (Jackson County Parks and Recreation, 2019). About one-half, or 292 square kilometers $\left(\mathrm{km}^{2}\right)$, of the drainage area of the Little Blue River watershed is regulated by reservoirs. 


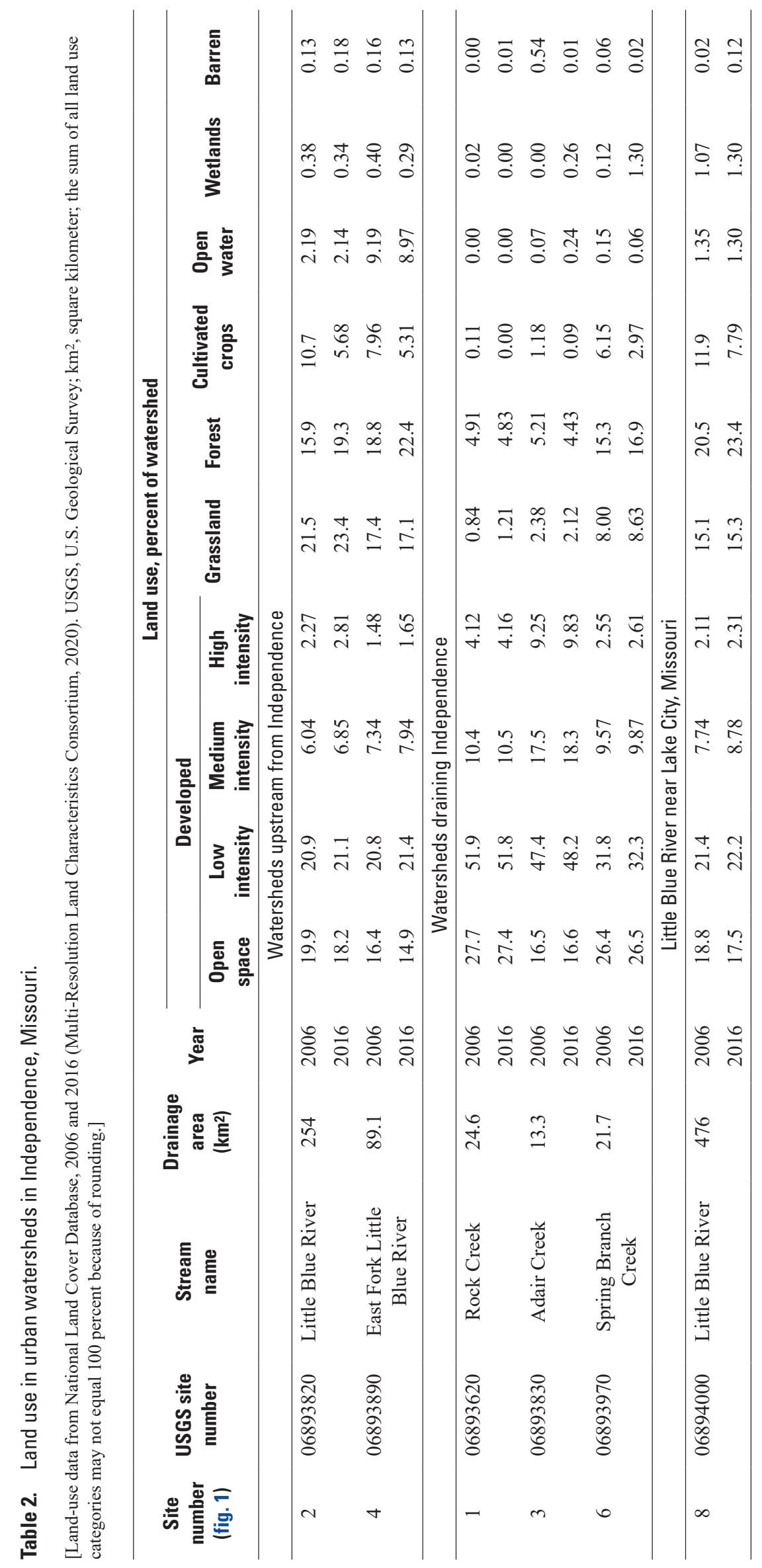




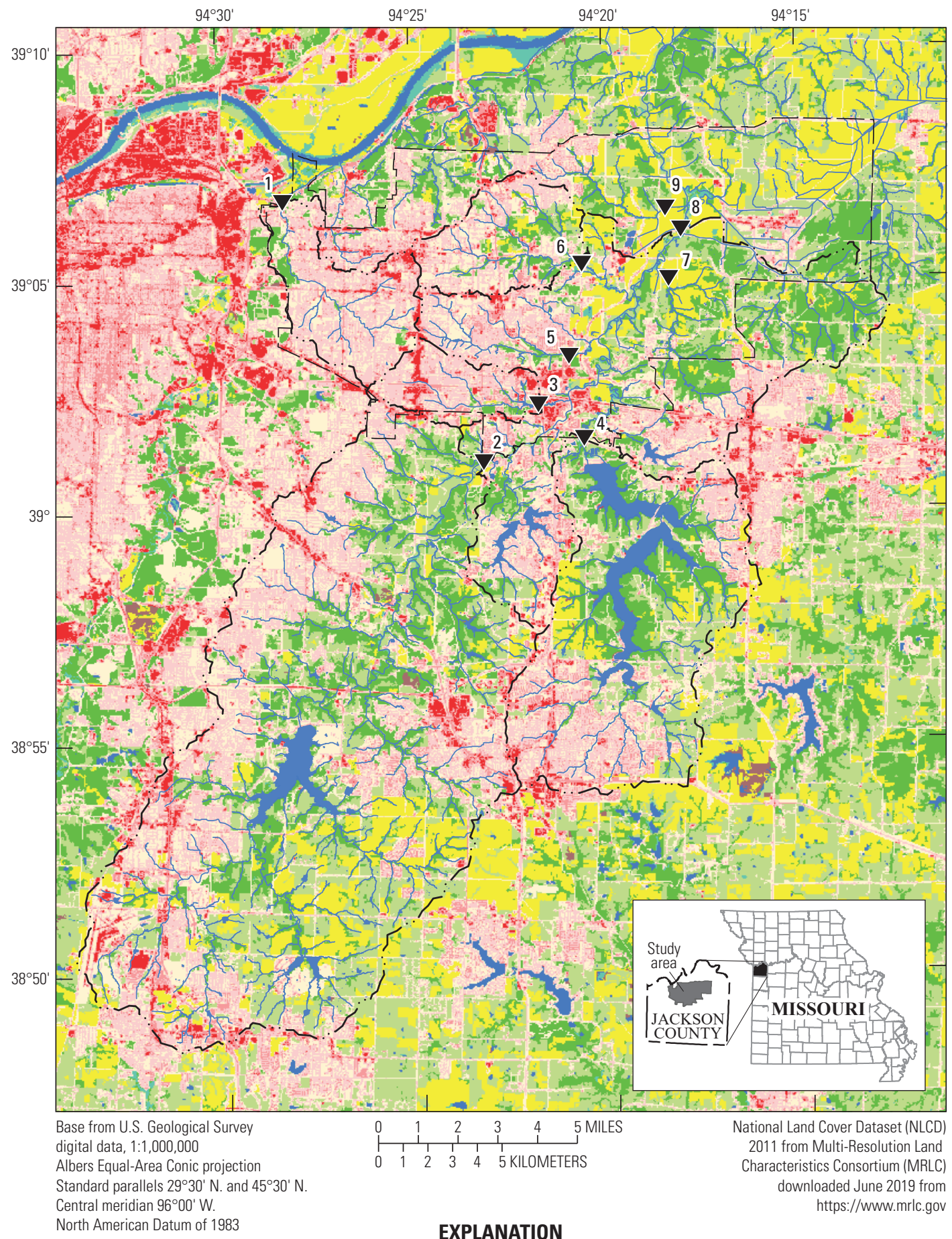

\begin{tabular}{|c|c|}
\hline 2011 National Land Cover Dataset & \\
\hline Developed, open space & Forest \\
\hline Developed, low intensity & Cultivated crops \\
\hline Developed, medium intensity & Open water \\
\hline Developed, high intensity & Wetland \\
\hline Grassland & Barren \\
\hline
\end{tabular}

- - - Watershed boundary

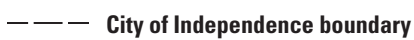

1 Sampling site and site number (fig. 1; table 1)

Figure 3. Land use/land cover in the Little Blue River Watershed and adjacent watersheds within Independence, Missouri. 

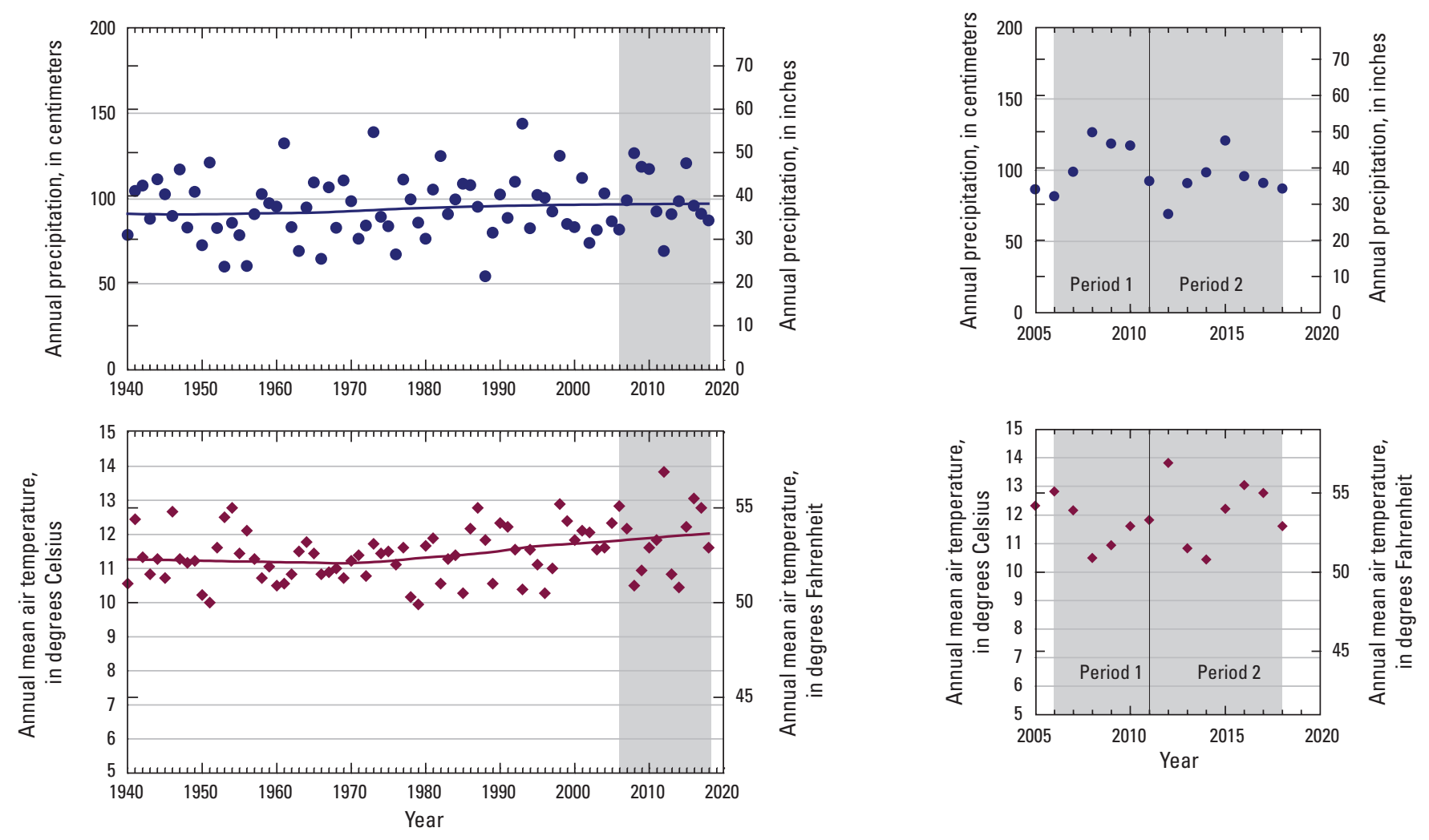

EXPLANATION

[Data from Midwestern Regional Climate Center, 2019]

Study period used for trend analysis (2006-18)

LOESS smooth

Air temperature

Precipitation

Figure 4. Annual mean precipitation and air temperature in northwestern Missouri in relation to long-term trends, $2006-18$.

Annual maximum flows in the Little Blue River have remained relatively constant at less than $200 \mathrm{~m} 3 / \mathrm{s}$ since 1949 (fig. 5). Exceptional flow events were in 1977 and 1982 when flow in the Little Blue River near Lake City, Mo., peaked at 413 and $784 \mathrm{~m}^{3} / \mathrm{s}$, respectively (U.S. Geological Survey, 2019). The next two greatest annual maximum flows were during the study period. The third-greatest annual maximum flow since 1949 was $297 \mathrm{~m}^{3} / \mathrm{s}$ in 2007, and the fourth-greatest annual maximum flow was $267 \mathrm{~m}^{3} / \mathrm{s}$ in 2017 .

Slightly lower air temperatures reducing evapotranspiration and more precipitation generating more runoff (fig. 4) probably were contributing factors that resulted in greater annual streamflow in the Little Blue River during period 1 (2006-10) than in period 2 (2011-18; fig. 5). The mean annual streamflow in the Little Blue River near Lake City, Mo. (site 8$)$, was greater during period $1\left(5.97 \mathrm{~m}^{3 / \mathrm{s}}\right)$ than during period 2 (3.97 m³/s; fig. 5). Mean annual flow was not significantly ( $p$ greater than 0.05 , Wilcoxon rank-sum test) different between the two periods, likely due to the large variability during period 1 (fig. 5).

Streamflow in the Little Blue River is affected by reservoirs at Longview Lake on the main stem of the Little Blue River and at Prairie Lee Lake, Lake Jacomo, and Blue Springs Lake on the East Fork Little Blue River (fig. 1). Longview Lake and Blue Springs Lake reservoirs are most immediately upstream from Independence on the Little Blue River and East Fork Little Blue River, respectively, and both reservoirs affect base flow. Low-flow releases from Longview Lake are maintained at a minimum of about $0.20 \mathrm{~m}^{3} / \mathrm{s}$, but low-flow releases are not maintained from Blue Springs Lake (Christensen and others, 2010). 
Little Blue River near Lake City, Missouri; U.S. Geological Survey site number 06894000 Study site 8 (fig. 1; table 1)
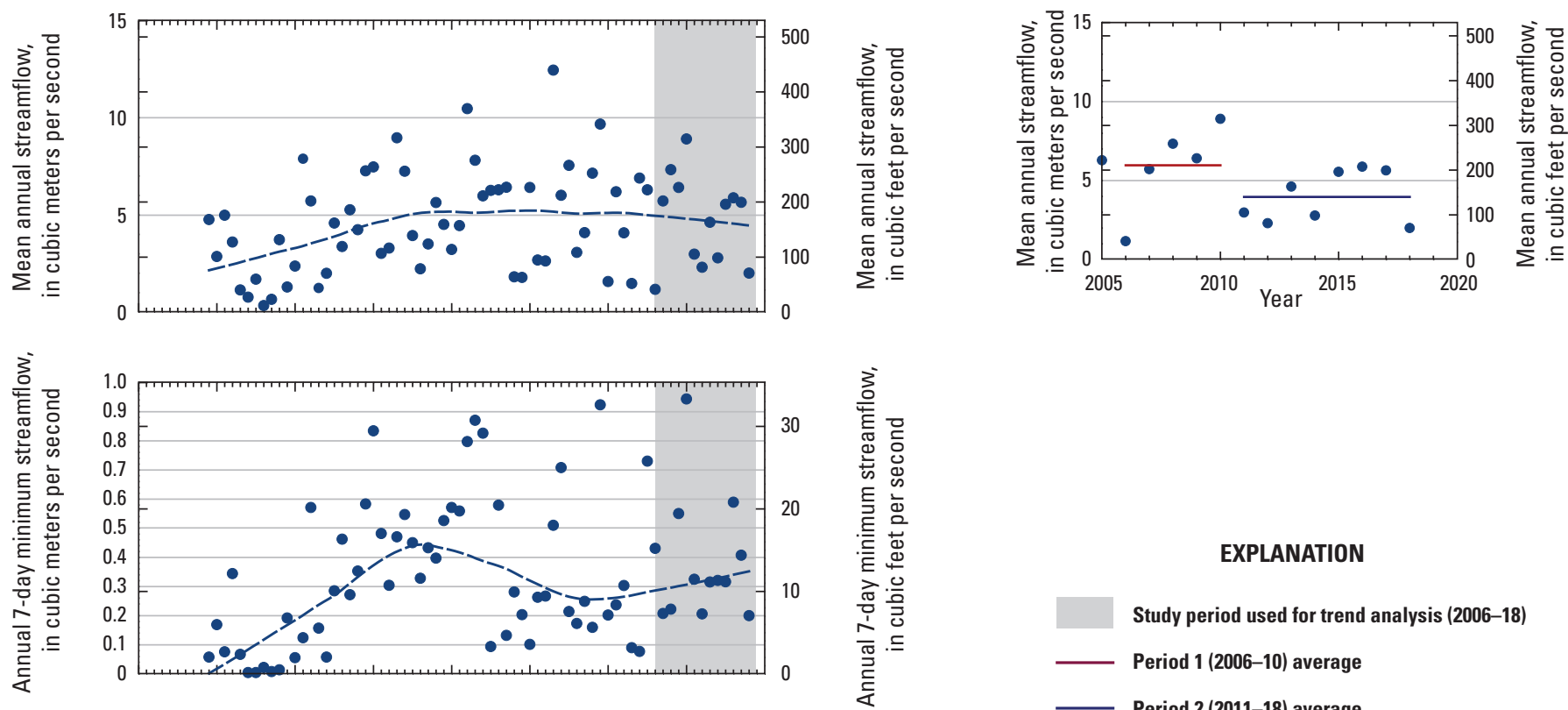

\section{EXPLANATION}
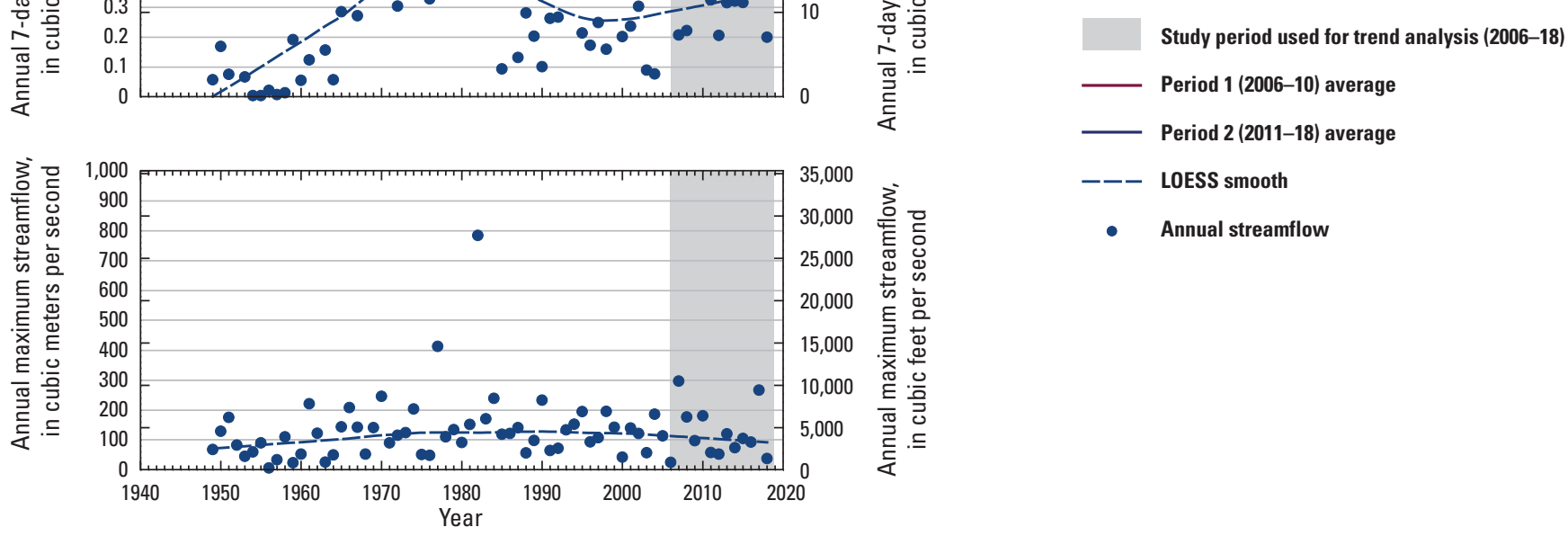

- Annual streamflow

Figure 5. Streamflow conditions from 2006-18 in relation to long-term streamflow conditions in the Little Blue River near Lake City, Missouri (streamgage 06894000; U.S. Geological Survey, 2019).

\section{Methods}

Various data obtained within the study period were used to evaluate trends in concentrations and loads for selected constituents at select sites. Not all constituents analyzed or sites within the study area were applicable for trend evaluations because of the length of time in which data were collected, periods of no data collection within the dataset, or other reasons that did not fit criteria for the models used.

\section{Water-Quality and Streamflow Data}

The hydrologic monitoring network within Independence consists of USGS streamgages and ungaged sampling sites, which both have varied data collection periods during the length of the study (table 1). Other streamgages have periodically been operated within Independence, through the NURP study (U.S. Environmental Protection Agency, 1983) and through the USGS streamgaging network in 1992 and 1993 (Schalk, 1994). Since 2005, water-quality samples have been collected from 11 sites in the Little Blue River watershed that are representative of Independence's contribution to the water quality of the Little Blue River and to streams that drain developed areas of Independence that receive streamflow from the MS4. Of these 11 sampling sites, the 9 sites that are currently (2019) active since 2015 are listed in table 1; 6 of these 9 sites were used in the analyses in this report. Sampling sites, sampling intervals, and constituents collected were based on MS4 permit requirements as well as the city's stormwater management plan.

As the regulatory requirements and management plans changed throughout the years, the study objectives also changed to meet the needs of the city. From 2005 through 2008, four sites (sites 1, 5, 6, and 8; table 1) were selected for stormwater and base-flow samples. Stormflow samples were collected four times per year (seasonally) and one base-flow sample was collected per year. The next phase of the study 
(2009-14) had a sampling plan of four stormwater samples collected at six sites (sites 1, 2, 3, 4, 6, and 8) seasonally, an additional two stormflow samples collected at three ungaged sites (sites 5, 7, and 9) per year, and two base-flow samples collected at all nine sites each year. To help characterize changes in constituent concentrations and bacteria population densities across various streamflows, the study was modified to monthly sampling at all nine sites from 2015 through 2019. The monthly sample collections were during the recreational period (April through October) for the nine sites. During the nonrecreational period, two base-flow samples were collected at the original six sites (sites 1, 2, 3, 4, 6, and 8). From 2015 through 2018, two stormwater samples were collected at four sites (sites 1, 2, 6, and 8) each year. Some sites used in the study have changed to more-suitable upstream or downstream locations or were discontinued depending on the project objectives and scope (table 1).

Data from four study sites that had at least 10 years of streamflow and periodic water-quality samples were used for trend analysis (sites 1, 2, 3, and 8). Some of the water-quality constituents that are required by the MS4 permit for analysis and other select constituents with consistent datasets were selected for concentration and load trends, when applicable. These constituents are as follows: the physical properties of water temperature, specific conductance, $\mathrm{pH}$, and dissolved oxygen; the nitrogen species total nitrogen (TN), total organic nitrogen (TON), dissolved ammonia as nitrogen (hereinafter referred to as ammonia), total ammonia plus organic nitrogen as nitrogen, and dissolved nitrate plus nitrite as nitrogen (hereinafter referred to as nitrate plus nitrite); the phosphorus species dissolved orthophosphate as phosphorus (ortho-P) and total phosphorus (TP); dissolved chloride; FIB (E. coli and total coliform); TDS; and suspended sediment. The TN values are not analytically derived concentrations but are the sum of dissolved nitrate plus nitrite, ammonia, and other organic nitrogen concentrations.

Surface-water-quality samples were collected during the study using approved USGS methods documented in U.S. Geological Survey (2006). For example, samples were collected by using equal-width increment or grab sampling methods for base-flow samples and by using automated samplers for stormflow collections. Further details of data collection techniques used for this study have previously been discussed by Christensen and others (2010), Christensen and Krempa (2013), Niesen and Christensen (2015), and Bushon and others (2017). All water-quality and streamflow data used in trend analyses are available online from the USGS National Water Information System (NWIS) database (U.S. Geological Survey, 2019) using the USGS site numbers in table 1.

\section{Trend Analysis}

Changes, or trends, in the water quality in urban streams in Independence, Mo., were evaluated by documenting changes in selected physical properties; concentrations of total and dissolved nutrients, dissolved chloride, TDS, and suspended sediment; and population densities of FIB transported from each watershed. Trends were investigated for the various constituent concentrations at four urban stream sites ( sites 1, 2, 3, and 8) and constituent loads were computed and investigated at six urban stream sites (sites 1, 2, 3, 4, 6, and 8). To compute annual results, both concentration and load trend analysis datasets contained samples collected from January 2006 through December 2018.

\section{Analysis of Concentration Trends}

A statistical time-series model developed by the USGS was used for analyzing complex, flow-related trends in water-quality constituents. The model is used for parametric statistical inferences and uses maximum likelihood estimation to determine complex trends, flow-related variability, and seasonal serial correlation. The model is operated using a publicly available software package called R-QWTREND (Vecchia, 2005; Vecchia and Nustad, 2020). This package is a collection of functions written in $\mathrm{R}$, a free, open-source language used for statistical and graphical interpretations and computations (R Development Core Team, 2019). An advantage to using this particular model for trend analyses is the ability to model serial correlation among observations and to model complex trends during different times as well as different directions, such as upward or downward, within the analysis period. The R-QWTREND also can identify and remove variability in streamflow to compute a flow-averaged trend and flow-weighted annual concentrations to represent trends that would have occurred if flow conditions were the same for each year in the time period. The software package also identifies and removes potential step trends in datasets. The step trends are the result of the compiled data being collected by various agencies and methods, or the data being processed by various laboratory methods (Vecchia and Nustad, 2020). The R-QWTREND requires a complete record of daily mean streamflow measured at the same streamgage as the discrete water-quality samples are collected. Water-quality data from sites $1,2,3$, and 8 representing three watersheds met the model criteria of a minimum of 60 discrete samples collected during a 10-year period, with four or more samples collected per year as required for model estimates with low bias. The model also can interpret censored data, but no more than 25 percent of the dataset can be censored. Analyses can be performed with datasets that do not meet the minimum criteria, but the model errors could be highly biased (Vecchia and Nustad, 2020) and should be interpreted with caution. An example of commands used to run the R-QWTREND model for the study is in figure 1.1.

The specific time-series model used to reduce model error because of serial correlation such as periodic or seasonal correlation is called a periodic autoregressive moving average (PARMA) model. The PARMA model within R-QWTREND filters the serial correlation and is available in three model options described further in Vecchia and 
Nustad (2020) to adjust for error that vary in model parameter estimates. Outliers are defined within the model parameters of R-QWTREND as an observation with an absolute value of the standardized residual from the trend model that is larger than 3.5 in absolute value (Vecchia and Nustad, 2020). Any data exceeding the outlier range were flagged within the model steps for review and either were removed or corrected in the original dataset used for the trend analysis. All outliers removed from the trend analyses for each site and constituent are documented in table 1.2.

The R-QWTREND program uses Gaussian maximum likelihood estimation to fit the model parameters, chooses the best trend model, and determines the significance levels (probability $[p]$-values) associated with the trends (Vecchia, 2000; Vecchia and Nustad, 2020). For this study, results were compared with all nested model results (null [no trend] and 1-period trend), and statistically significant trends were identified when the probability value ( $p$-value) was less than 5 percent $(\alpha=0.05)$. Nested models also can be compared against 2-period trends, but because of the shorter analysis period available for this study, 2-period trend models were not determined as significant compared to the 1-period trend models. Therefore, 2-period trend models were not used. Generalized likelihood ratio tests were used to determine if the 1-period trend model was a significantly better fit than the null-trend model by the computed $p$-value (Vecchia and Nustad, 2020). Example output information from a best-fit model are listed in table 1.1 and are shown in figure 1.2. The magnitude of upward trends and downward trends was expressed as a percentage change in concentration between the beginning and ending years; the annual model-fitted median concentrations for beginning and ending years of the trend period also were reported.

\section{Statistical Procedures}

Select constituents were analyzed for significant differences among sites using Tukey's nonparametric, multiple comparison test (Helsel and others, 2020). If sites were not significantly different, meaning the attained significance level, or $p$-value, was greater than 0.05 , the sites were noted with the same letter. If left-censored data (reported as less than a method reporting limit) were included in the dataset used, these data were set to one-half the smallest method detection level reported within the study period (Helsel and others, 2020). For calculated parameters such as TN and TON, all censored values were set to the smallest censored value in the dataset. Estimated values were used as the value reported. One outlier was removed for site 6 because all results reported for the sample collected on May 3, 2006, were flagged with value qualifiers, indicating the results were affected by unknown contamination.

Summary statistics were computed for select constituents at the four sites used in the concentration trends analyses (table 1.3). In addition to routine, descriptive statistics such as minimum, maximum, mean, and median values, the number and percentage of censored values within a constituent's observed value dataset also were provided. These summary statistics were necessary for proper model selection and evaluation within R-QWTREND.

\section{Analysis of Load Trends}

Annual loads of selected nutrients, dissolved chloride, and suspended sediment for 2006-18 were estimated by the Weighted Regressions on Time, Discharge, and SeasonKalman filter (WRTDS-K) model described in Zhang and Hirsch (2019). The WRTDS-K model was used to estimate loads for all nitrogen and phosphorus compounds and suspended sediment. Research by Lee and others (2019) showed that the WRTDS-K model results in more accurate estimates of annual loads for many constituents than Load Estimator (LOADEST; Runkel and others, 2004). Based on this research, the WRTDS-K model was the first choice for estimating annual nitrogen and phosphorus species, chloride, and suspended-sediment loads (SSLs). The WRTDS-K model, which is an updated version of the Weighted Regressions on Time, Discharge, and Season (WRTDS; Hirsch and De Cicco, 2015) model, accounts for the autocorrelation of residuals using a first-order autoregressive model and provides more accurate estimates of annual loads (Zhang and Hirsch, 2019). Daily mean streamflow and constituent concentrations from the analysis of periodic water-quality samples are input into the WRTDS-K model to estimate daily loads. Daily loads were summed to obtain annual loads. Optimal correlation coefficients for the nitrogen species (0.95), TP (0.875), ortho-P (0.875), chloride (0.90), and suspended sediment $(0.90)$ determined according to Zhang and Hirsch (2019) were used in the WRTDS-K model. Estimated annual loads of TN, TON, ammonia, nitrate plus nitrite, TP, ortho-P, chloride, and suspended sediment computed using WRTDS-K for this report are listed in tables 2.1 and 2.2.

Annual loads of E. coli were not computed for this report, because the WRTDS-K model can only estimate mass (in kilograms) and not populations (colonies of E. coli). Other modeling tools such as LOADEST also do not have a means for computation of a population density load, as the results are not a mass. Previous single-day load estimations for E. coli presented in Bushon and others (2017) were directly computed for a specific sampling date using daily mean flow and mean $E$. coli density. Because samples analyzed for population density of $E$. coli were not collected daily, or even monthly in most of the study period, estimation of annual mean $E$. coli loads with single-sample load computation would not be a valid representation of temporal and spatial changes within $E$. coli population density loads for the study period and, therefore, could be misinterpreted. 


\section{Comparisons of Model Estimates}

Earlier estimates of annual loads of nitrate plus nitrite, ammonia, TON, TN, TP, chloride and suspended sediment in urban Independence streams used the LOADEST model (Runkel and others, 2004) to estimate annual loads transported in urban streams in Independence (Christensen and others, 2010; Niesen and Christensen, 2015). To provide a comparison to the previous LOADEST model calculations, the dataset used by Niesen and Christensen (2015) also was analyzed using the WRTDS-K model, and a comparison of the two model results for site 8 is shown in figure 6 . The difference in the results between these two models using the same datasets at site 8 are summarized in tables 3.1 and 3.2. Although varying from year to year, the mean difference between the annual loads from the LOADEST and WRTDS-K models is less than 20 percent. The annual load estimate from the WRTDS-K model is generally greater than the LOADEST models for the nitrogen and phosphorus species and generally less than the LOADEST model estimate for chloride and suspended sediment (tables 3.1,3.2). The percentage difference in annual load estimates for the nitrogen species and TP tended to decrease as mean annual streamflow increased. The differences between the LOADEST and WRTDS-K estimated annual chloride loads were unrelated to mean annual streamflow. The SSL estimates from the LOADEST model became substantially greater than from the WRTDS-K model as annual streamflow increased.

\section{Statistical Procedures}

Two nonparametric trend tests were used to quantify trends in annual loads in streams in Independence. The MannKendall test was used to determine if the study period had a monotonic trend, and the Wilcoxon rank-sum test (Helsel and others, 2020) was used to understand the significance of differences between constituent load and yield during period 1 (2006-10) and period 2 (2011-18). Nonparametric statistics were used because annual load datasets were small and could not be assumed to be normally distributed.

\section{Land-Use Data}

Land-use data for the Independence-area urban watersheds were extracted from the National Land Cover Database (NLCD) satellite imagery database (appendix 4). NLCD data are geographic information system (GIS) coverages with 30-meter pixels classified by land cover largely based on Landsat imagery. NLCD coverages for 2006 and 2016 were used to bracket the study period to document land cover changes in individual watersheds. The boundaries of these watersheds were delineated using the USGS StreamStats webbased watershed mapping tool (Ellis, 2018). NLCD pixels falling within watershed boundary polygons were tallied by land-use category using the GIS software ArcGIS, and total and fractional areas of each land-use category within individual watersheds were calculated from this pixel tabulation. Land use in the NLCD coverage is classified into 20 major land-cover classes. To simplify analysis, similar NLCD classifications were grouped together into 10 categories (appendix 4). In the modified classification used for this report, forest

Little Blue River near Lake City, Missouri; U.S. Geological Survey site number 06894000 Study site 8 (fig. 1; table 1)

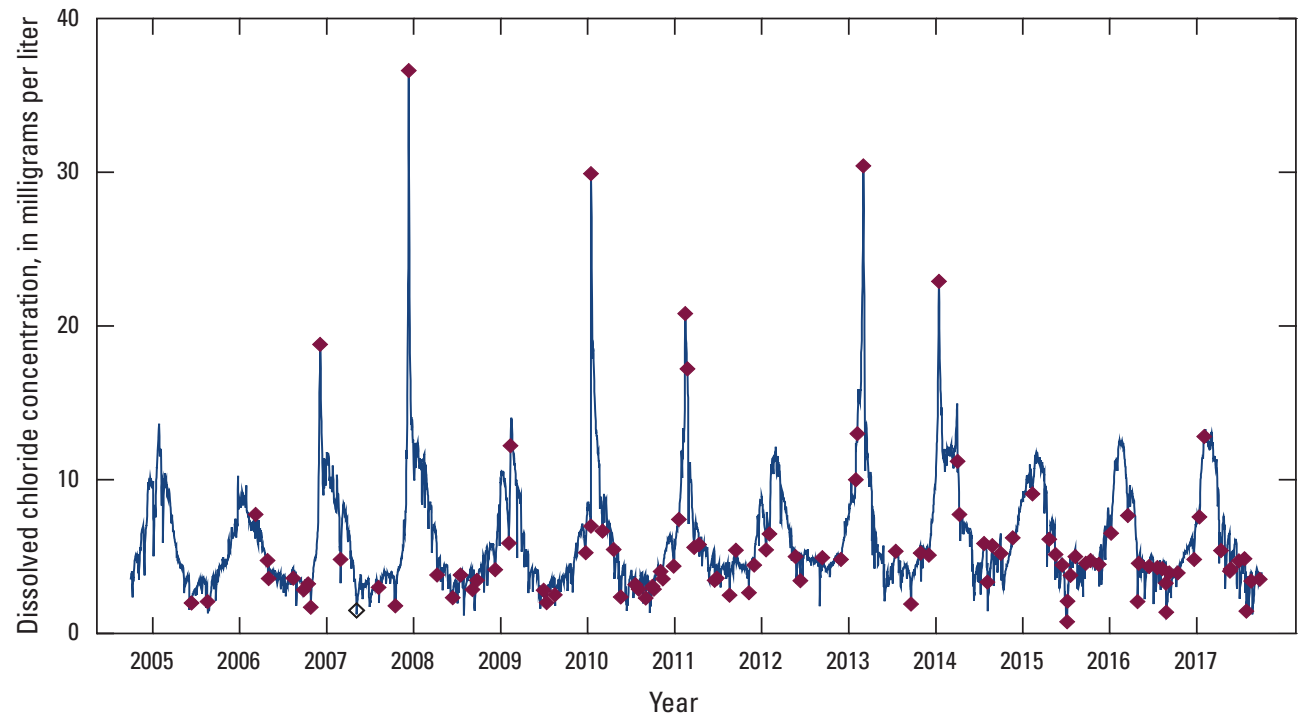

EXPLANATION

[WRTDS-K, Weighted Regression on Time, Discharge, and Season-Kalman filter]

WRTDS-K modeled concentration

- Analyzed concentration

Figure 6. Analyzed versus Weighted Regressions on Time, Discharge, and Season-Kalman filter (WRDTS-K) modeled concentrations for dissolved chloride at Little Blue River near Lake City, Missouri (streamgage 06894000), 2004-17. 
includes the deciduous, evergreen, and mixed forest NLCD classifications; grassland includes the shrub/scrub, grassland/ herbaceous, and pasture/hay classifications; and wetlands includes woody and emergent herbaceous wetlands. Because the study area contains large amounts of urban areas, all four "developed" categories were retained.

\section{Water-Quality Trends in Concentrations and Loads}

Available data collected from January 2006 through December 2018 for 15 water-quality physical properties and constituent concentrations were analyzed for trends at four study sites (sites 1,2,3, and 8). Summary statistics used to assist in selection of the best-fit models are available in table 1.3. Statistically significant, flow-weighted concentration trends are presented in table 3 as percentage change and magnitude of change for annual geometric mean and annual flow-weighted mean concentrations for each of the four sites. All available data for 2006-18 (full study period) were used that fit the requirements of the various trend models used in the study. If more than one site had a statistically significant trend for a select constituent, the flow-weighted trend was plotted, and the sites were indicated on a location map.

In addition to using the full period, a fixed period set as $2010-17$ was selected to compare trends among the four sites (table 4). Although this period was the longest period of consistent data collection for all four sites, the period does not meet the minimum criteria of 10 years for the R-QWTREND model to predict low-biased trends. Caution, therefore, should be used in interpreting such trends because of the increased risk for error (Vecchia and Nustad, 2020).

Load trends were analyzed to document changes in transport into Independence and transport from urban streams within Independence. The annual load contribution from the Little Blue River within Independence, including its monitored tributaries (sites 3 and 6) was calculated as the difference in annual load at site 8 from the sum of the annual load entering the city at site 2 on the Little Blue River and at site 4 on the East Fork Little Blue River. The annual loads within Independence also included loads flowing directly to the Missouri River from Rock Creek (site 1).

\section{Trends in Physical Properties}

Select physical properties analyzed for trends in concentrations during the study period are water temperature, dissolved oxygen, specific conductance, and $\mathrm{pH}$. These physical properties, which are measurements in the field, can assist in the understanding of the current conditions of a stream at the time of sampling. Many constituents are dependent on water temperature and can degrade or react at certain temperatures. Particular fish species also can thrive within certain ranges of water temperature better than other species. Dissolved oxygen is important to aquatic life for survival. Lower concentrations of dissolved oxygen can be an indicator of higher concentrations of suspended particulates and organic material in the stream that can limit light and algal photosynthesis or increase demand for dissolved oxygen through oxidation of reduced organic material. The solubility of dissolved oxygen in water also decreases with increasing temperature. Specific conductance is the measurement of dissolved ions in the water and the ability of dissolved ions to carry an electrical charge or current, at a specified temperature.

The collection of physical properties provided datasets that met the requirements of the model analyses; however, few trends were identified. When trends were investigated for each site within the full period of record as listed in table 3, site 1 had a statistically significant trend in $\mathrm{pH}$ (upward, table 3), and site 2 had a statistically significant trend in dissolved oxygen (downward, fig. 7). Site 8 had statistically significant trends in water temperature (upward, table 3), dissolved oxygen (downward, fig. 7), and specific conductance (upward, table 3).

\section{Trends in Nutrient Concentrations and Loads}

The nutrients nitrogen and phosphorus are essential for plant and animal nutrition, but if excessive concentrations of nutrients are present in water bodies, the nutrients can cause water-quality concerns such as algal blooms, fish kills, and taste and odor issues in drinking water sources. Nutrient concentrations reflected in TN, TON, total ammonia plus organic nitrogen as nitrogen, nitrate plus nitrite, TP, and ortho-P were analyzed at four sites (sites 1, 2,3, and 8). Ammonia data did not meet the minimum criteria for model requirements at the four sites because ammonia was not consistently sampled until 2013, but data were included in the summary statistics (table 1.3).

Trends in TN concentrations were investigated using the full period of available data for each site, and results indicated statistically significant downward, single-period trends at all four sites (table 3; fig. 8). The largest percentage change in the annual flow-weighted mean concentration from beginning year to end year was at site 8 with 46.9 percent (table 3). Although sites 1,2, and 3 had varying lengths of trend periods, each site had consistent changes in annual flow-weighted mean concentrations (about 23-30 percent decrease, table 3) from the beginning to end of the period of data for each site. The TN concentrations were highest at site 1 (table 3 ), but the downward trend in TN could be a result of infrastructure improvements in the Rock Creek watershed.

Using the full period of data for each site, concentrations of TON had a downward trend at all sites, and all trends were significant except at site 3 (table 3; fig. 9). Site 1 had the largest percentage change in flow-weighted concentration (56.4 percent) during the site's trend period (table 3). The decrease in TON at site 1 could be a result of infrastructure improvements within the Rock Creek watershed. Downstream 


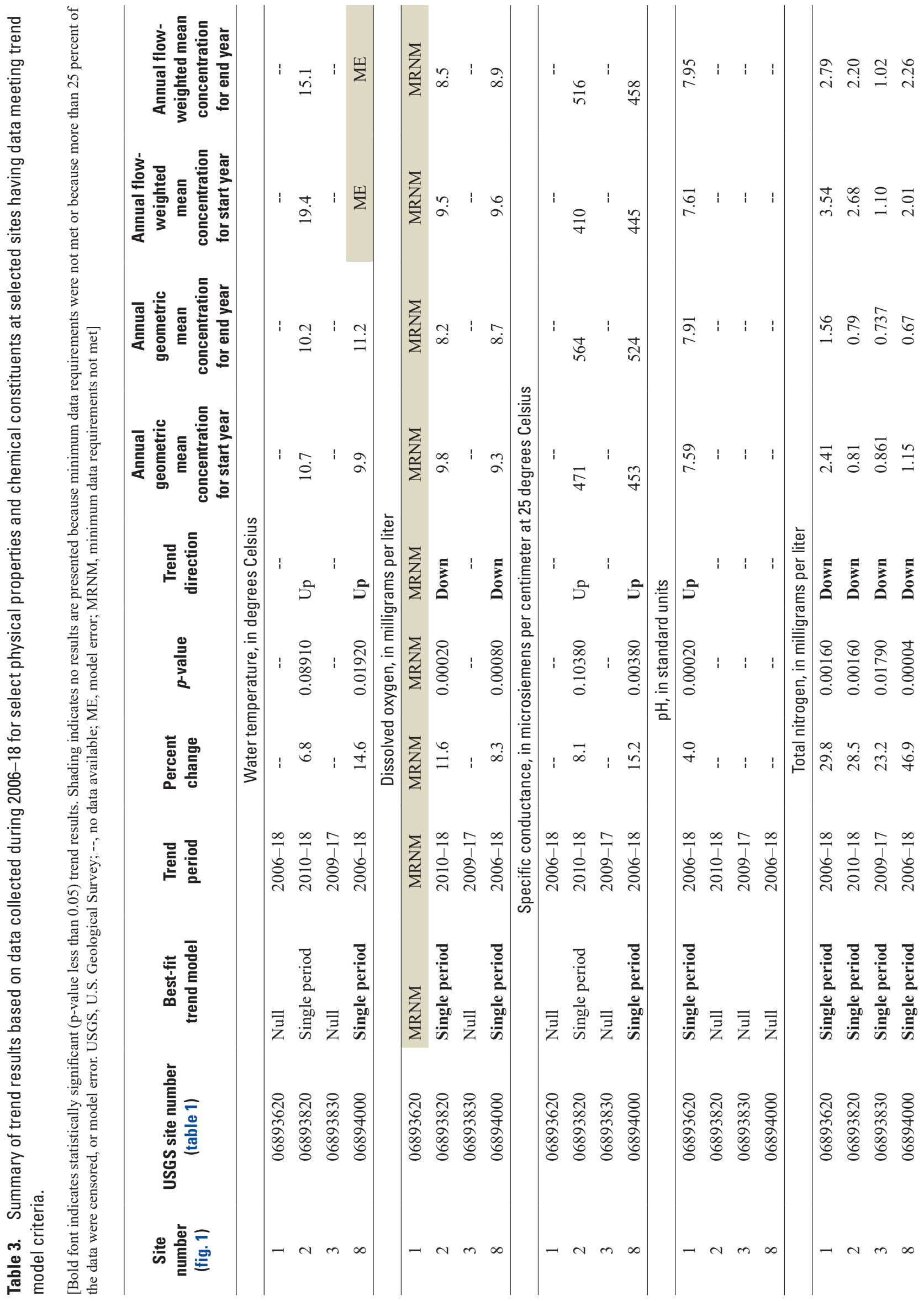




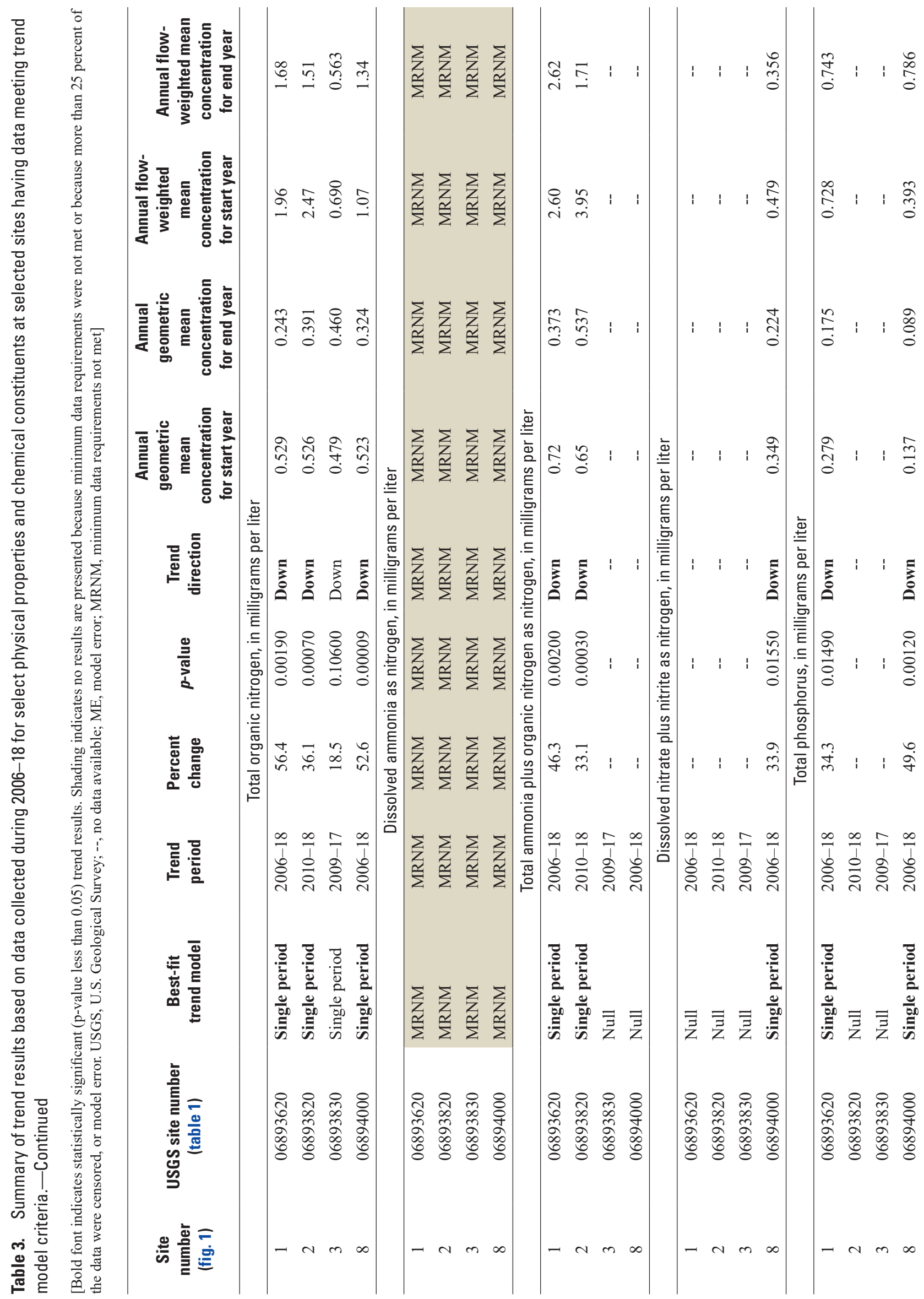




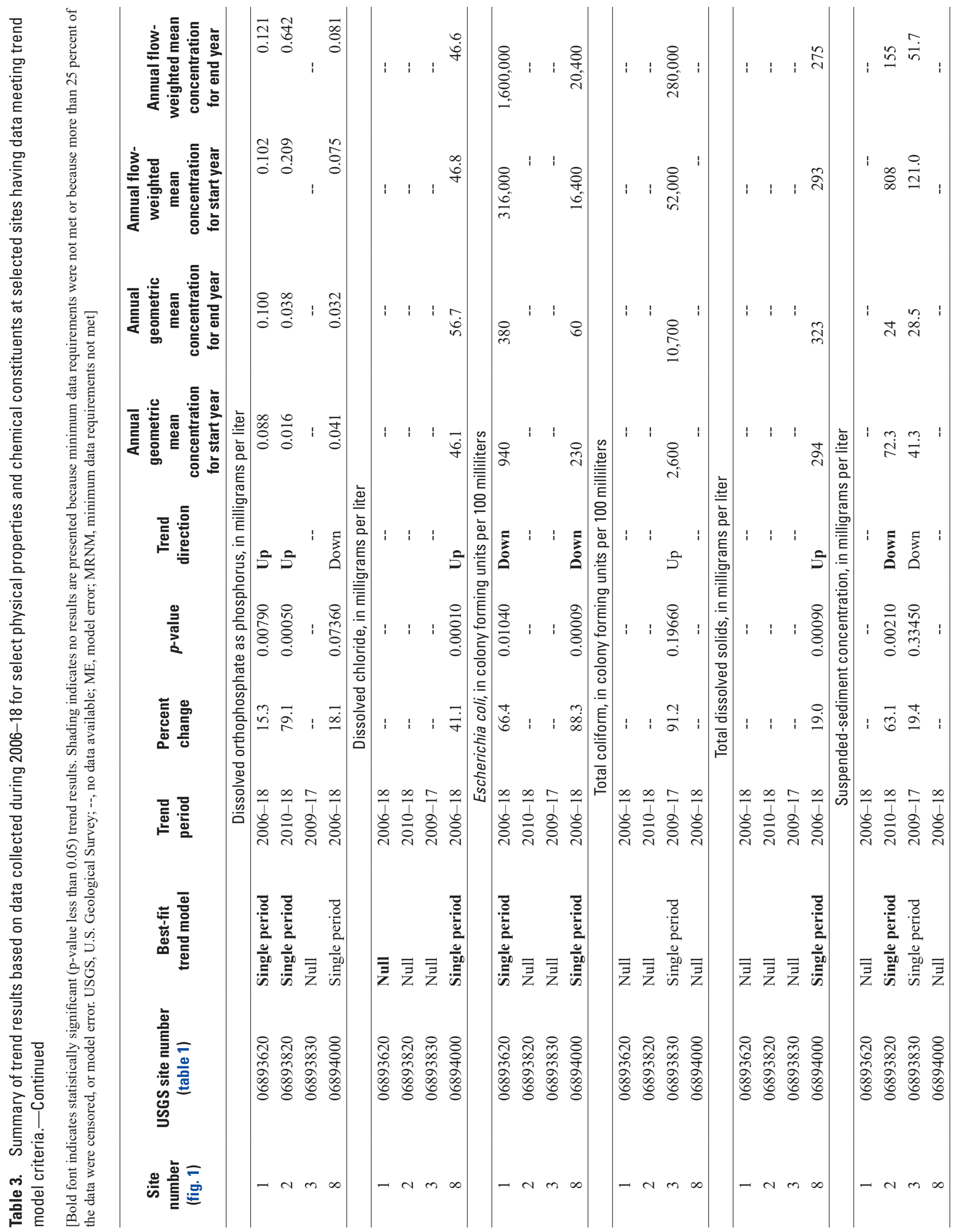




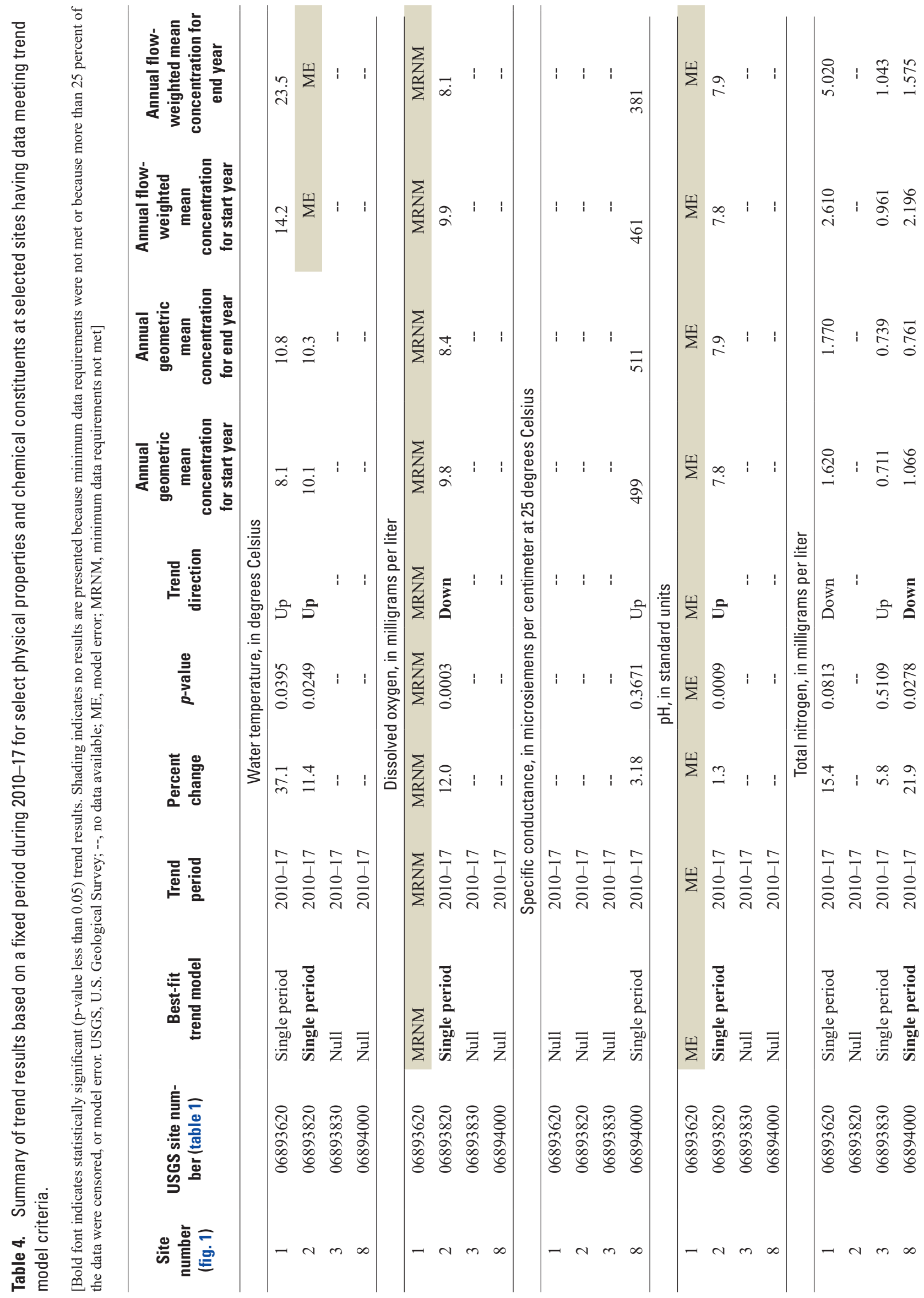




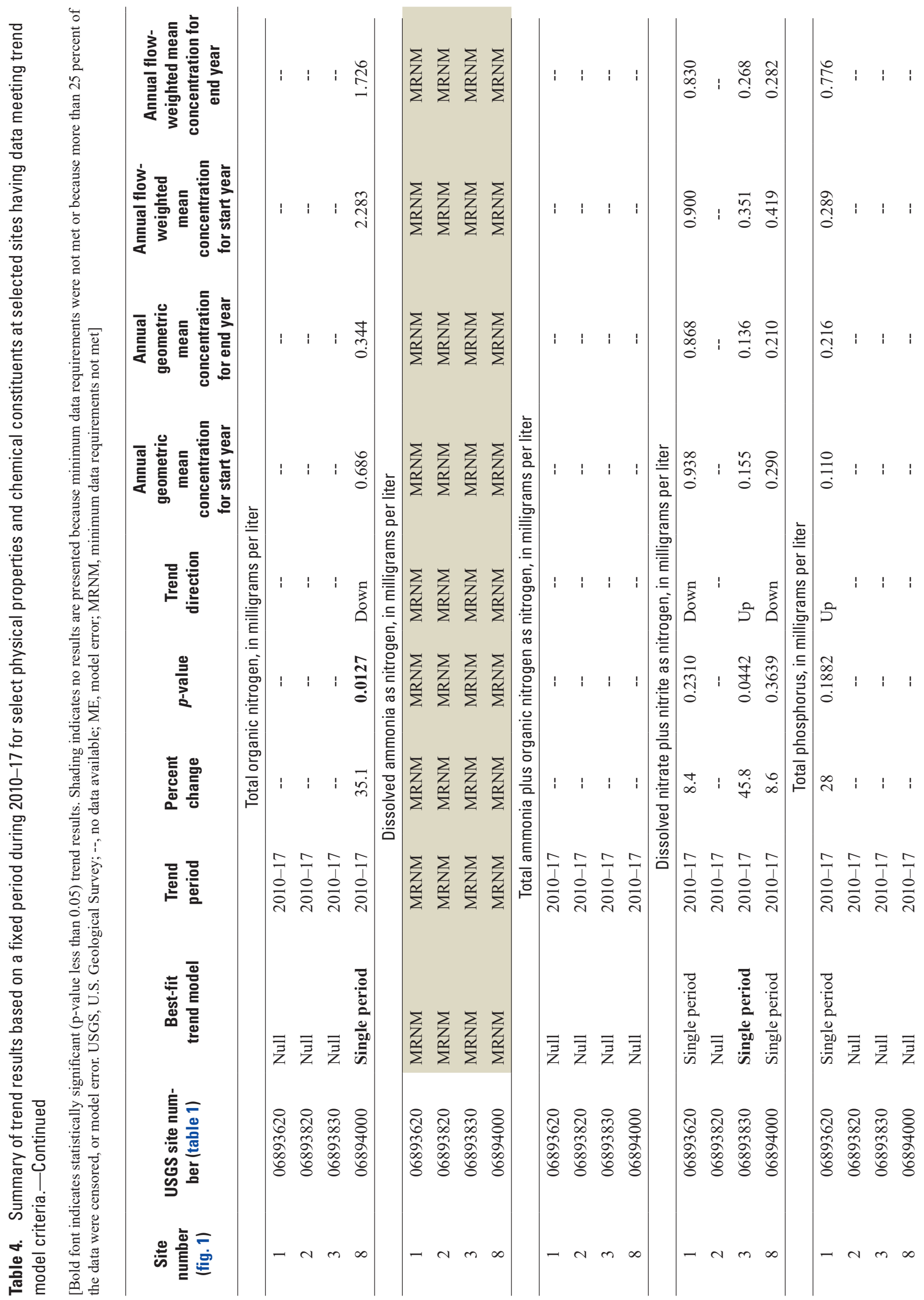




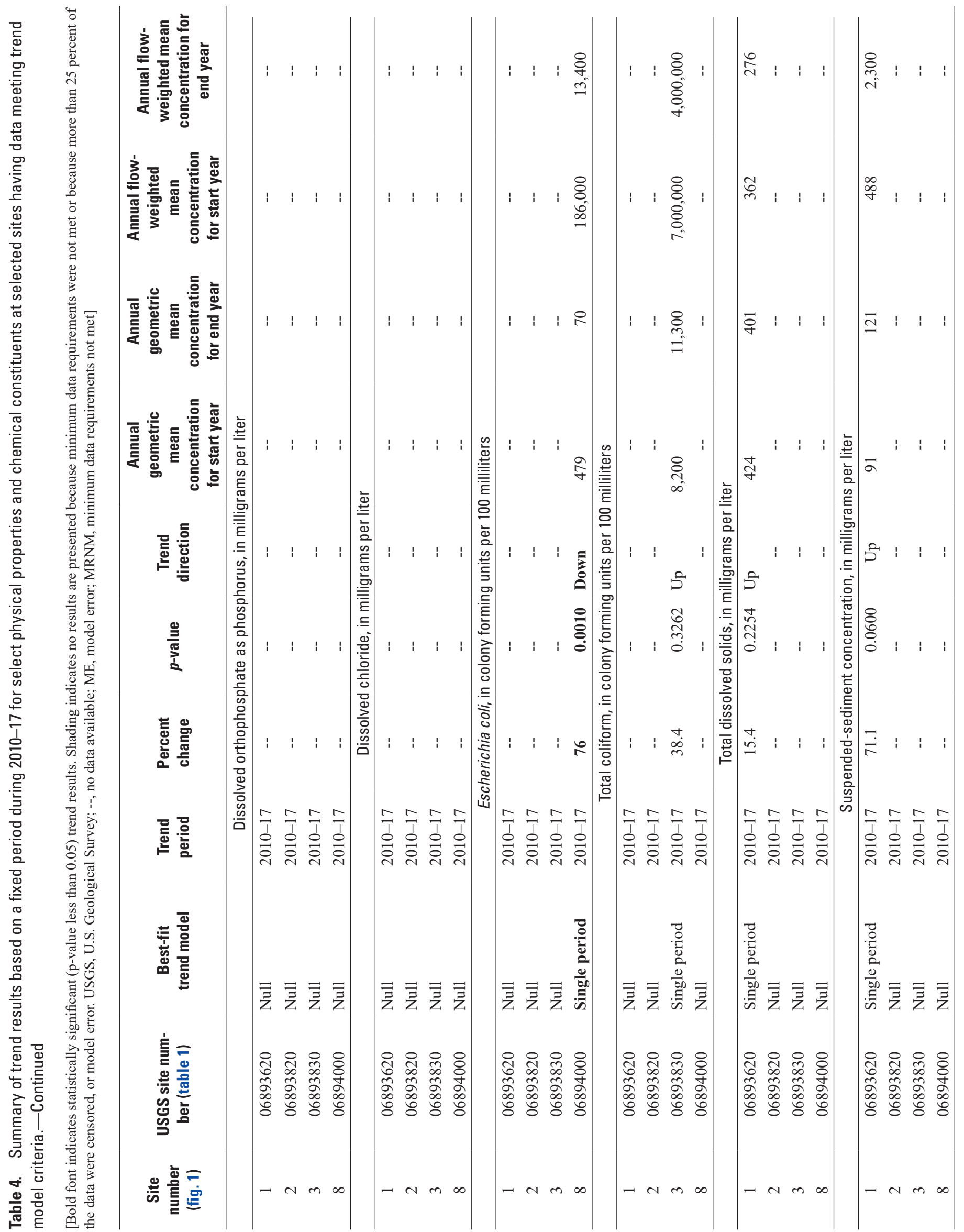



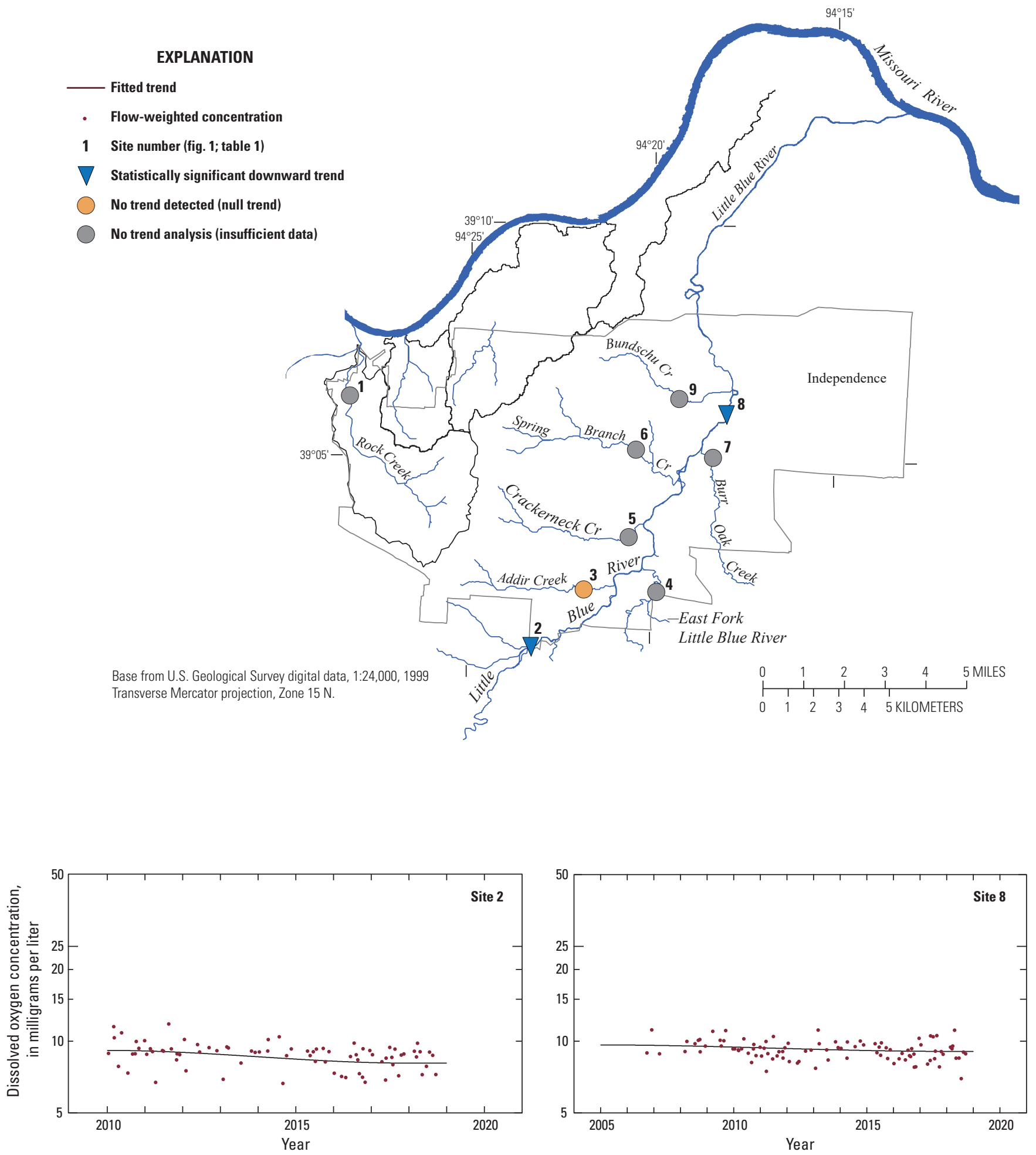

Figure 7. Location map and graphs of sites with statistically significant trends in flow-weighted dissolved oxygen concentrations from 2006 through 2018. 


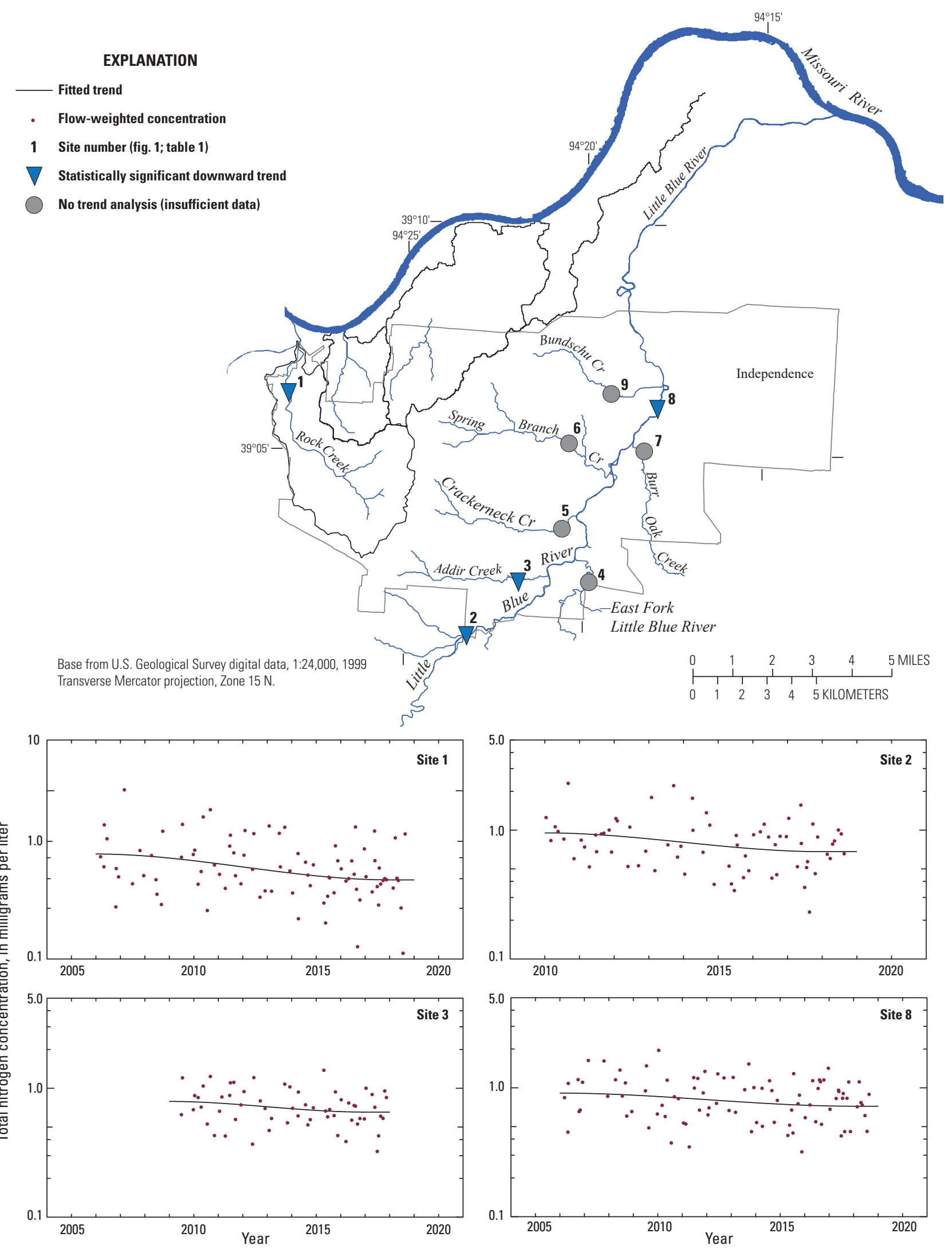

Figure 8. Location map and graphs of sites with statistically significant trends in flow-weighted total nitrogen concentrations from 2006 through 2018. 


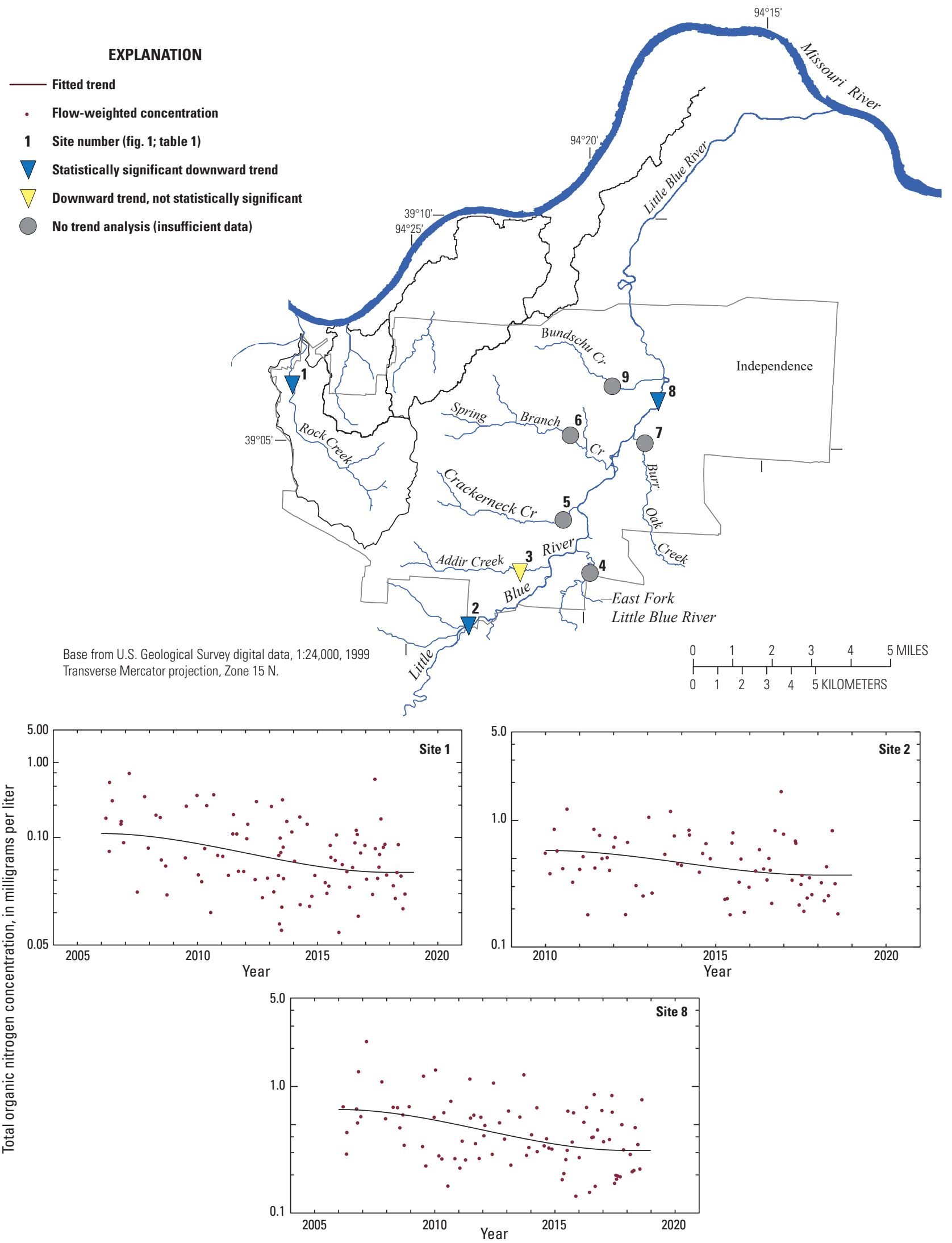

Figure 9. Location map and graphs of sites with statistically significant trends in flow-weighted total organic nitrogen concentrations from 2006 through 2018. 
downward trends were noted on the Little Blue River for sites 2 and 8 , with the larger decrease observed in the downstream site 8 (fig. 9).

The remainder of nutrient constituents investigated for trend analyses had fewer statistically significant trends. Downward trends were identified at sites 1 and 2 for total ammonia plus organic nitrogen as nitrogen (fig. 10). Only one statistically significant trend was identified in flow-weighted nitrate plus nitrite concentrations at site 8 (table 3 ). The TP concentrations showed statistically significant downward trends at sites 1 and 8 (fig. 11), but flow-weighted, annual concentrations increased from first year to the end year in the analysis period (table 3 ). The increase in flow-weighted concentrations may be a result of a change in sampling from the beginning of the study, which targeted stormflow conditions, to a more consistent and hydrologically dynamic sampling program implemented in 2015.

The only nutrient constituent with an upward trend was flow-weighted ortho-P concentrations at sites 1 and 2 (fig. 12). Ortho-P is commonly detected in fertilizers, residential detergents, and organic waste in sewage and effluent (U.S. Environmental Protection Agency, 2019). Of the various forms of phosphorus, ortho-P is more readily available for biological consumption. The percentage change of annual flowweighted mean ortho-P concentrations was smaller at site 1 (15.3 percent) than at site 2 (79.1 percent; table 3 ). The cause of increased flow-weighted ortho-P concentrations at these sites is not apparent. The upstream area has had some land-use change during the study period, with slight increases (1 percent or less) in developed low-, medium-, and high-intensity land use from 2006 through 2016 (table 2). The greatest difference in land-use changes upstream from the MS4 (site 2) was cultivated croplands, which decreased by about 50 percent, and forest land, which increased by 3.4 percent from 2006 through 2016 (table 2).

A study performed in urban watersheds of St. Paul, Minnesota (not shown; Hobbie and others, 2017), determined that excess nitrogen and phosphorus inputs to watersheds were from residential sources but occurred in different ways. The study indicates nitrogen concentrations in surface waters were reduced by intake from the atmosphere and increased contamination in groundwater, and increased phosphorus concentrations were transported from impervious surfaces and storm drains to surface waters. Results from this study indicated that in urban areas across the Nation, consistent sources of nutrients were predominantly from residential lawn fertilizers, yard waste (grass clippings and leaf litter), and pet waste. The upward trend in flow-weighted ortho-P concentrations at site 2 could be attributed to residential practices similarly described in the St. Paul study, particularly in the areas with increased residential development, as well as the increase in forested areas upstream from Independence.

Significant downward trends were identified in flowweighted TN and TON concentrations at site 8 within the full (2006-18) period (table 3) and the fixed (2010-17) period (table 4). Although the results from the fixed period warrant using with caution because of the datasets not meeting the minimum criteria for the model, analysis of the fixed period allowed for trend comparison within more of the latter part of the study when samples were collected representing a greater range in streamflow conditions and seasons. The significant downward flow-weighted trends in the full period of available data and the fixed period at site 8 may indicate that downward trends are not necessarily a result of an environmental change such as land use, precipitation, or streamflow, but perhaps indicate the effect from changes in sampling methodology during the study. The consistent downward trends in the full period of available data and the fixed period also may be indicative of improved wastewater and stormwater management practices within the MS4 boundaries.

Annual loads of nitrogen species were computed for TN, TON, ammonia, and nitrate plus nitrite, of which only ammonia had a statistically significant trend (table 5). Results indicated a small nonstatistically significant decrease in the annual TN load transported from the Little Blue River and its tributaries from 2006 through 2018 (tables 2.1, 2.2). During the full study period, the small downward trend in annual TN loads was correlated with annual streamflow and was generally not a monotonic trend, but rather a step trend from the wetter first period (2006-10) to the drier second period (2011-18).

The annual TN load transported in the Little Blue River within Independence, Missouri (downstream from sites 2 and 4 and upstream from site 8), was about 109,100 kilograms (kg; table 6). The annual TN load transported from Independence at site 1 was about 42,300 $\mathrm{kg}$ (table 7). A large part of the nitrogen in the Little Blue River (72 percent) and in Rock Creek (69 percent) transported from within Independence was in the form of TON (tables 6, 7). Ammonia made up the smallest part of the TN load transported from Independence in the Little Blue River ( 0.6 percent) and Rock Creek (about 2 percent). The Little Blue River within Independence contributed a mean of 43 percent of the TN, 41 percent of the TON, 34 percent of the nitrate plus nitrite, and 15 percent of the ammonia load identified at site 8 (table 6). The TN load at sites 1, 2, 3, 6, and 8 decreased from period 1 (2006-10) to period 2 (2011-18) for all nitrogen species except ammonia at site 3 (table 7).

In contrast to the $\mathrm{TN}$, nitrate plus nitrite and TON loads remained relatively constant, and ammonia loads transported from the Little Blue River Watershed at site 8 decreased significantly through the 2006-18 study period (table 5, fig. 13). The ammonia loads decreased about 7 percent per year. Although there was a significant decreasing linear trend, the significantly smaller loads during the drier 2011-18 period (fig. 13) affected the overall 2006-18 trend in ammonia load, and the overall trend could be reduced to a step trend ( $p$-value of 0.04, Wilcoxon rank-sum test) between the first (2006-10) and second (2011-18) study periods. The downward trend in ammonia loads was due to smaller amounts of ammonia originating from within Independence as the ammonia load entering Independence at site 2 and site 4 remained constant. The 

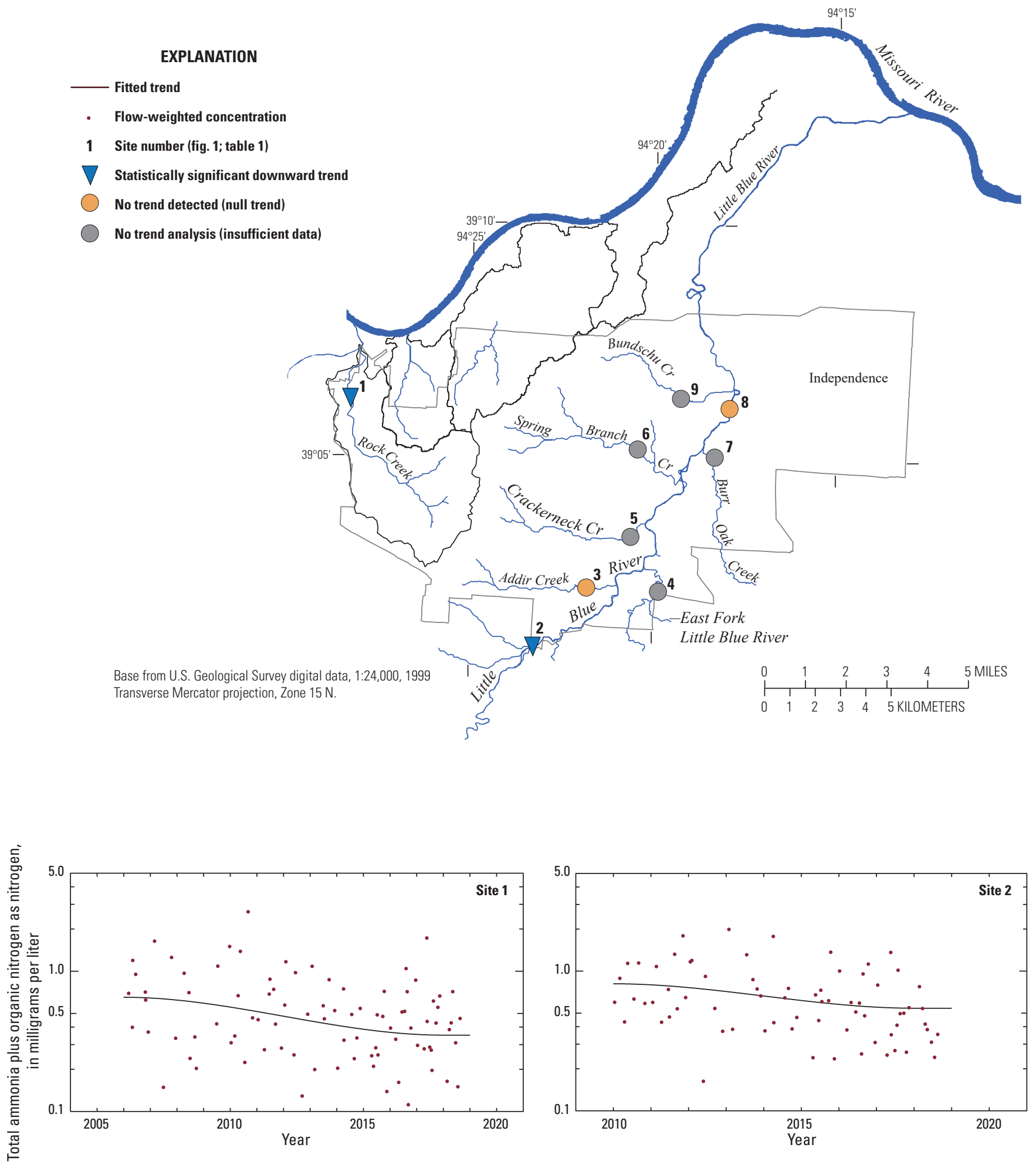

Figure 10. Location map and graphs of sites with statistically significant trends in flow-weighted total ammonia plus organic nitrogen as nitrogen concentrations from 2006 through 2018. 

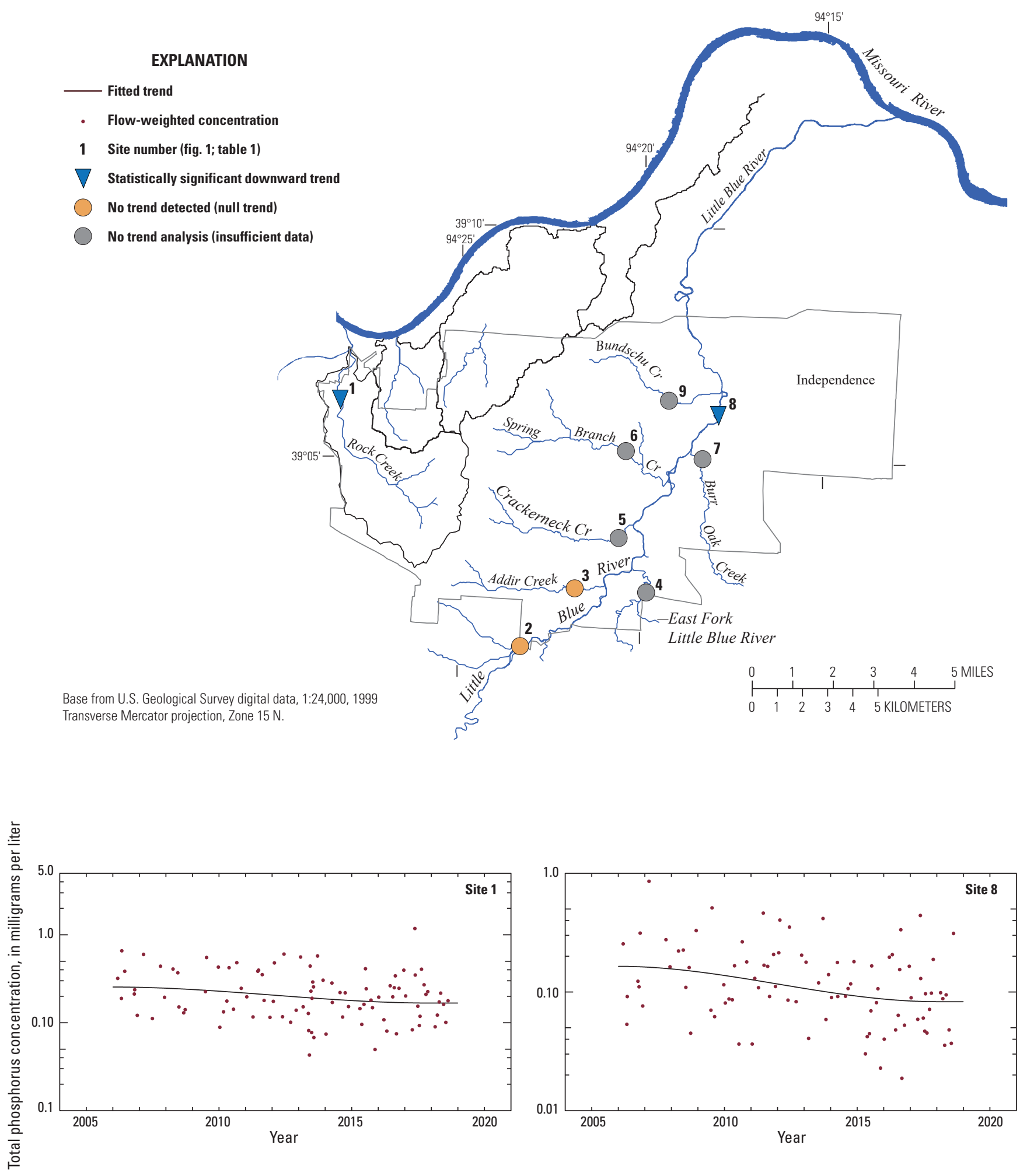

Figure 11. Location map and graphs of sites with statistically significant trends in flow-weighted total phosphorus concentrations from 2006 through 2018. 

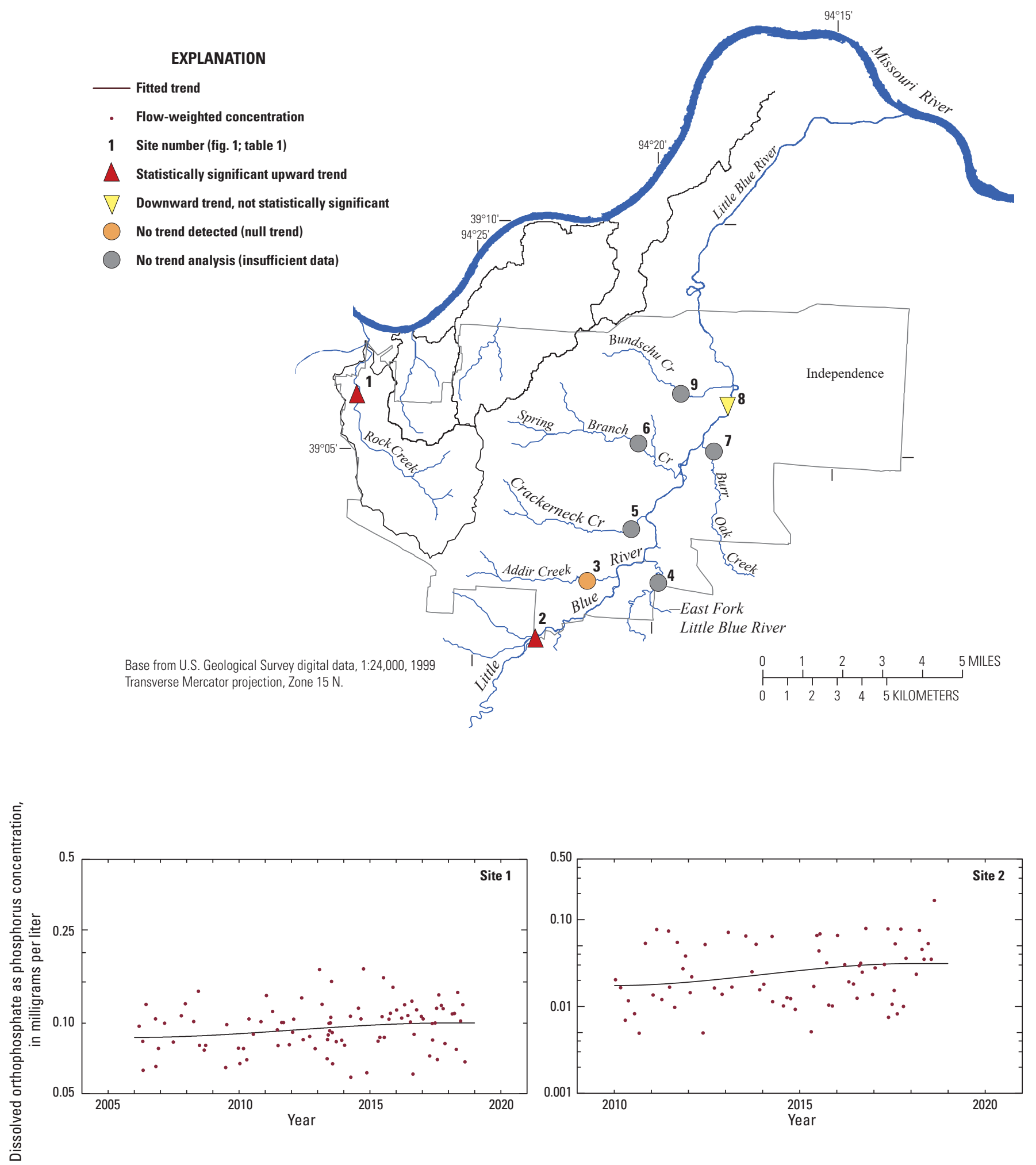

Figure 12. Location map and graphs of sites with statistically significant trends in dissolved ortho-phosphate as phosphorus concentrations from 2006 through 2018. 


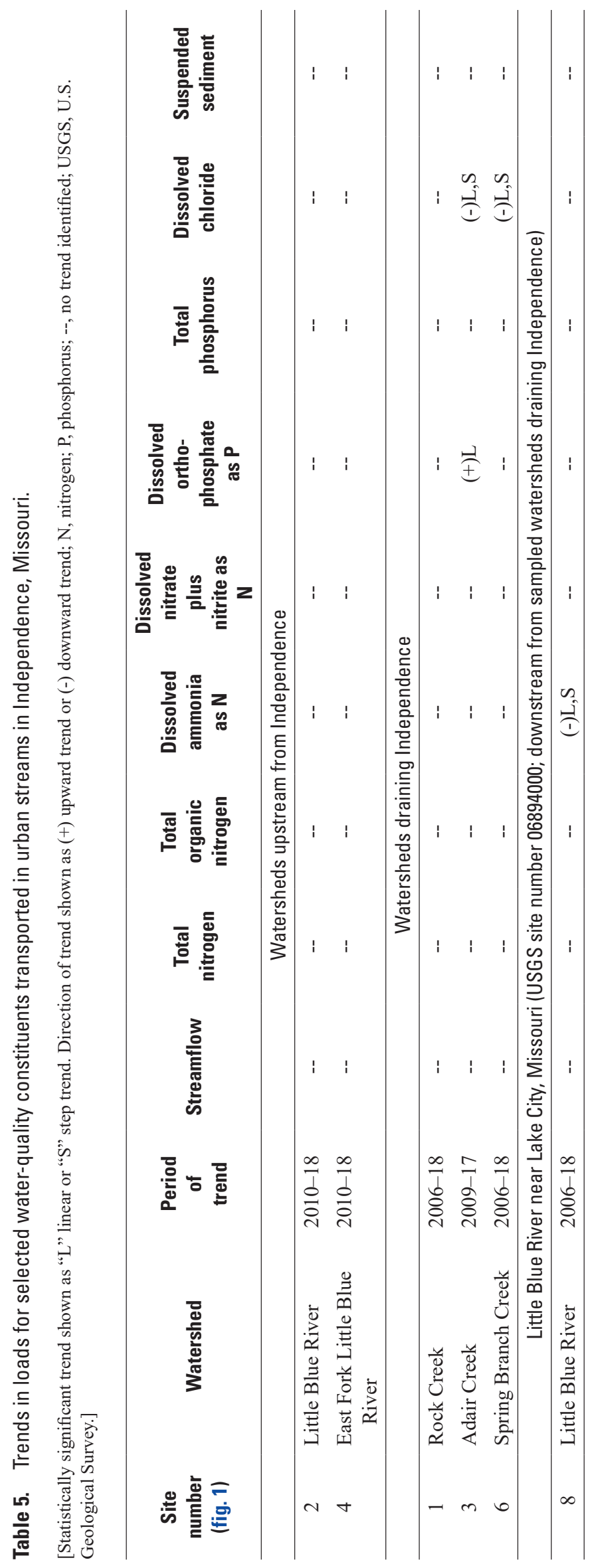




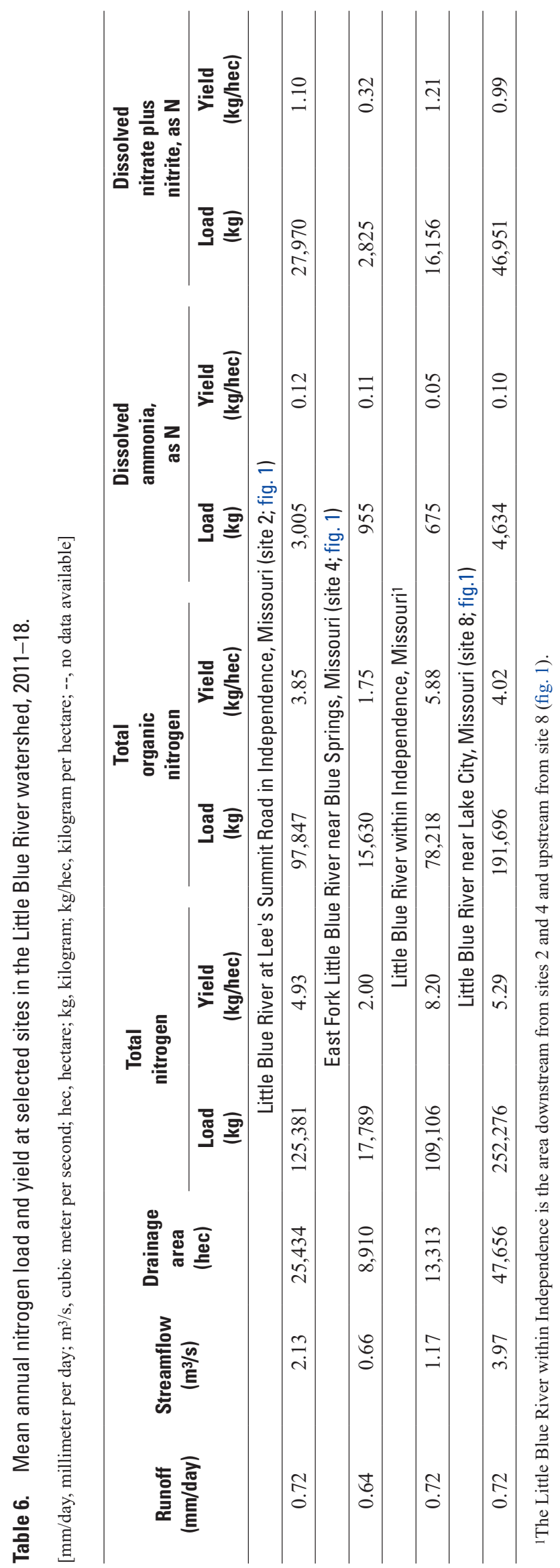




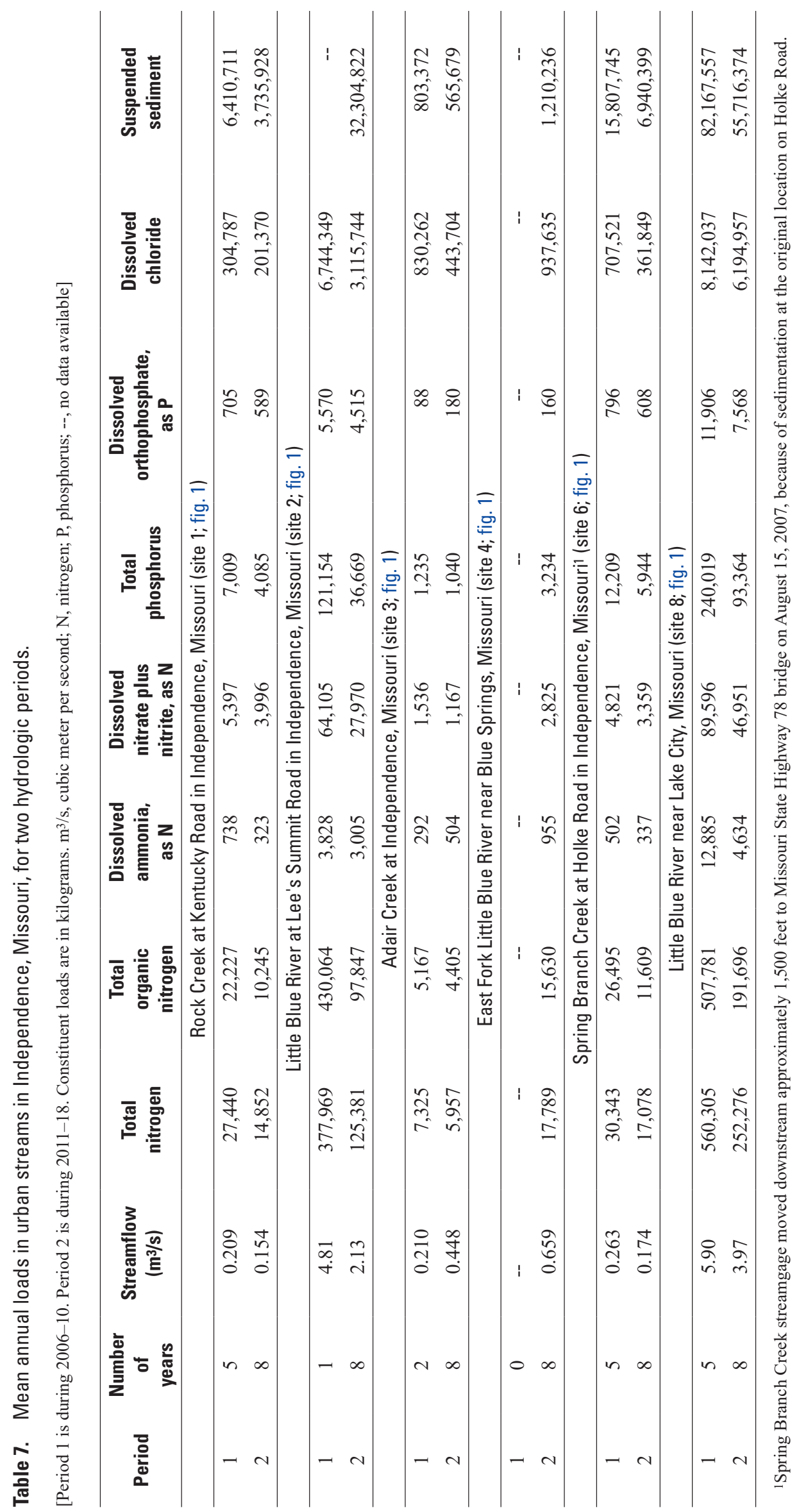


ammonia reduction within Independence occurred in Spring Branch Creek (table 2.1) and potentially in other unmonitored urban streams.

As with nitrogen, there were small but nonstatistically significant decreases in the loads of TP and ortho-P transported from the Little Blue River and its tributaries from 2006 through 2018. The downward trends were caused by reduced streamflow from period 1 to period 2 that are reflected in larger period-1 mean annual loads compared to period-2 mean annual loads (table 7). The annual TP loads at site 6 and site 3 , streams draining the city, also generally decreased in relation to annual streamflow, but the trends were not statistically significant. An exception to the overall downward trends in phosphorus transport was a significant upward linear trend in annual ortho-P load at site 3 on Adair Creek (table 5). The annual ortho-P load from Adair Creek increased from less than $100 \mathrm{~kg}$ in 2009 to more than $200 \mathrm{~kg}$ in 2017 (table 2.2). Overall, TP transported to the Little Blue River from the city of Independence constituted about 57 percent of the annual TP load at downstream site 8 during the 2011-18 period. The ortho-P load originating from Independence is only 19 percent of the ortho-P load at site 8 . An additional $6,800 \mathrm{~kg}$ of TP, of which $652 \mathrm{~kg}$ is ortho-P, is transported annually from site 1 .

\section{Trends in Chloride and Total Dissolved Solids Concentrations and Loads}

Of the major ions collected as part of the MS4 permit requirements, dissolved chloride had the largest dataset and fit the minimum criteria for using R-QWTREND for determining trends in the concentrations. Chloride can come from various sources such as salts (applied to roadways during the winter for snow and ice removal), water treatments (water softeners), sewage, and fertilizers (Kelly and others, 2010). When trends were investigated by using the full period of available record for each site, a null or no trend was identified at three sites, and only site 8 had a significant trend (table 3 ). The trend at site 8 was upward, with a 41.1 percent increase in annual flow-weighted mean concentrations from 2006 through 2018 (table 3). Land-use changes (table 2) indicate small increases (about 1 percent or less) in developed low-, medium-, and high-intensity at site 8 ; however, increased road salt application near the site during the winter could have resulted in higher concentrated runoff during wet weather conditions.

The TDS concentrations were analyzed at sites 1, 2, 3, and 8 to identify if more trends were present in major ions that may not have had a large enough dataset to analyze individually. Significant trends in major ions can be from naturally occurring events but also can be effects of urbanization. When each site was analyzed by using the full period of available data, a significant upward TDS trend - similar to chloridewas indicated at site 8, with an increase in annual flowweighted mean concentration of 19 percent (table 3).

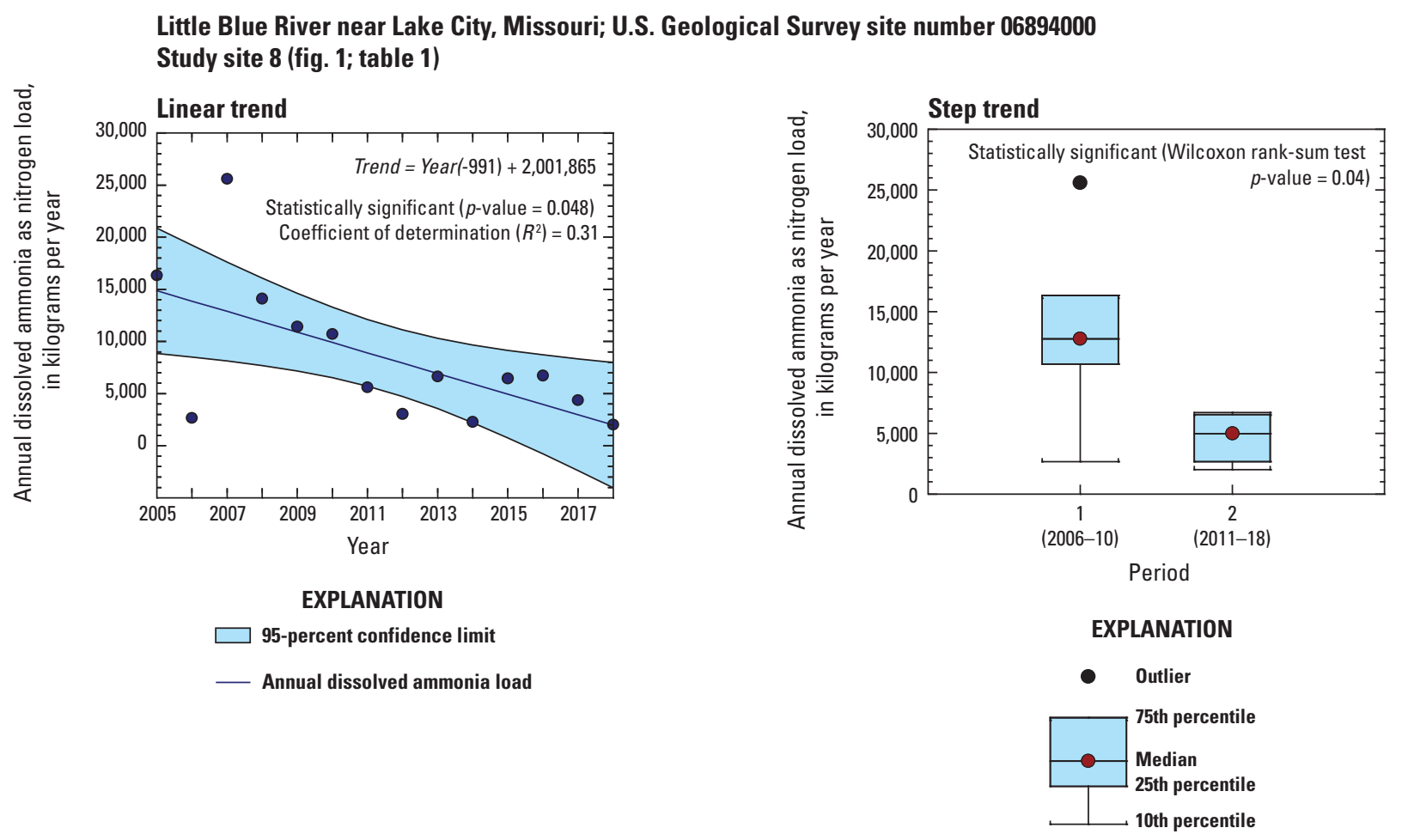

Figure 13. Significant trends in annual dissolved ammonia loads at the Little Blue River near Lake City, Missouri, 2006-18. 
No statistically significant change was indicated in the annual chloride load transported from the Little Blue River during the 2006-18 study period (table 5). However, with the exception of a dry 2006, annual chloride loads at the downstream Little Blue River site (site 8 ) were greater than $6,000,000 \mathrm{~kg}$ during the first 5 years of the study and decreased to less than $4,000,000 \mathrm{~kg}$ by the end of the study period (table 2.2). Annual chloride loads transported by Adair Creek (site 3) and Spring Branch Creek (site 6) significantly ( $p$-value greater than 0.05) decreased during the period that chloride loads were monitored (table 5). The mean chloride load at sites 3 and 6 decreased by nearly half from the wetter period 1 to the drier period 2 (table 7). Annual chloride loads at site 6 significantly ( $p$-value greater than 0.05 ) decreased from 929,763 kg in 2007 to $166,184 \mathrm{~kg}$ in 2018 (table 2.2). Although there was a significant linear decrease at site 6 , the mean chloride load transported in the drier (2011-18) period 2 was significantly ( $p$-value greater than 0.05 , Wilcoxon ranksum test) less than the chloride load transported during the wetter (2006-11) period 1 (table 7). These values indicate that trends in precipitation runoff are important factors in trends in annual transport of chloride from two of Independence's urban watersheds. For the study period, samples were collected primarily during the recreational period (April through October) until 2014; limited data were available during the winter (November through February) when road salt application typically occurs.

A small decrease in chloride loads also was indicated on Rock Creek (site 1), which transported chloride originating from Independence directly to the Missouri River (table 7). The annual mean chloride load at site 1 decreased about 34 percent from period 1 to period 2 (table 7), but the decrease was not statistically significant (table 5).

\section{Trends in Fecal Indicator Bacteria Population Density}

The FIB, such as E. coli and total coliform, are bacteria found in the intestines of warm-blooded animals and humans and can contain disease-causing organisms. These bacteria are measured to indicate the possible human-health risks of fecal contamination in urban and rural streams. Some urban and rural sources of FIB contamination include sewage overflows from older or failing infrastructure during heavy rainfall; improper connections between storm and sanitary sewer systems; leaking sanitary sewer lines and septic systems; and more traditional nonpoint sources such as livestock, domestic animals, wildlife, and biosolid spreading as fertilizer on agricultural land (Bushon and others, 2017). In urban areas during rainfall, bacteria density can increase in surface waters through runoff from impervious surfaces such as parking lots, roads, and roofs (Mallin and others, 2000). Increases in FIB densities during storm events can be indicative of stormwater runoff processes delivering contaminants from urban and rural sources. During the study period, FIB have been analyzed extensively by various methods. The Little Blue River and some of its tributaries upstream from and within Independence have been listed by the Missouri Department of Natural Resources (2018) as impaired for E. coli contamination from urban runoff and sewer sources. Characterization of the fecal contamination was identified previously as multiple nonhuman as well as some human sources and loads of $E$. coli. Population densities were determined to have no statistically significant differences between upstream from the city boundaries and downstream from the city boundaries (Bushon and others, 2017). The previous conclusions of E. coli density loads and yields performed in Bushon and others (2017) were not extrapolated or confirmed during the current (2019) study.

Trends in FIB population densities were investigated at four sites using the full period of record available for each site. Statistically significant downward trends were noted for sites 1 and 8 with 66.4 and 88.3 percent change, respectively, in annual flow-weighted mean population densities from 2006 through 2018 (table 3; fig. 14). The annual geometric mean concentration of $E$. coli population density decreased during the trend period, but the flow-weighted annual mean population density increased from 2006 through 2018 for sites 1 and 8 . The changes in data collection methodology during the period of record could have affected the annual flow-weighted mean densities because samples were collected primarily during stormflow events for most of the study (2006-13). From 2014 through 2018, samples were collected with more temporal and spatial variance to gain more data within various streamflow conditions, which also increased the number of samples per year. Improvements within the MS4 to stormwater and wastewater infrastructure also could be a result of the downward trends in FIB population densities, particularly for site 1 .

The $E$. coli densities at sites 2 and 8 on the Little Blue River support conclusions in Bushon and others (2017) that FIB concentrations were not significantly different from upstream (site 2) to downstream (site 8) of the MS4 area and have remained unchanged during the study period. The upstream Little Blue River site (site 2) had a null trend for the full period of data, which indicates no statistically significant changes in E. coli population density from 2010 through 2018 upstream from the MS4 boundary. Site 8 had a statistically significant downward trend in available data from 2006 through 2018. Streamflow in the Little Blue River increases downstream as the drainage area increases by nearly 50 percent from site 2 to site 8 (table 1). Because the trends predicted with R-QWTREND are flow adjusted, the effect of streamflow is held constant throughout the time period modeled. The downward trend of $E$. coli population density at site 8 could be a result of dilution from increased streamflow volume downstream, the decrease in streamflow and precipitation during the study period, storage of FIB in the Little Blue River streambed within the MS4, die-off of FIB during travel from upstream to downstream, infrastructure improvements within the MS4 boundary, changes in the sample collection methodology as described previously, or a combination of these factors. 

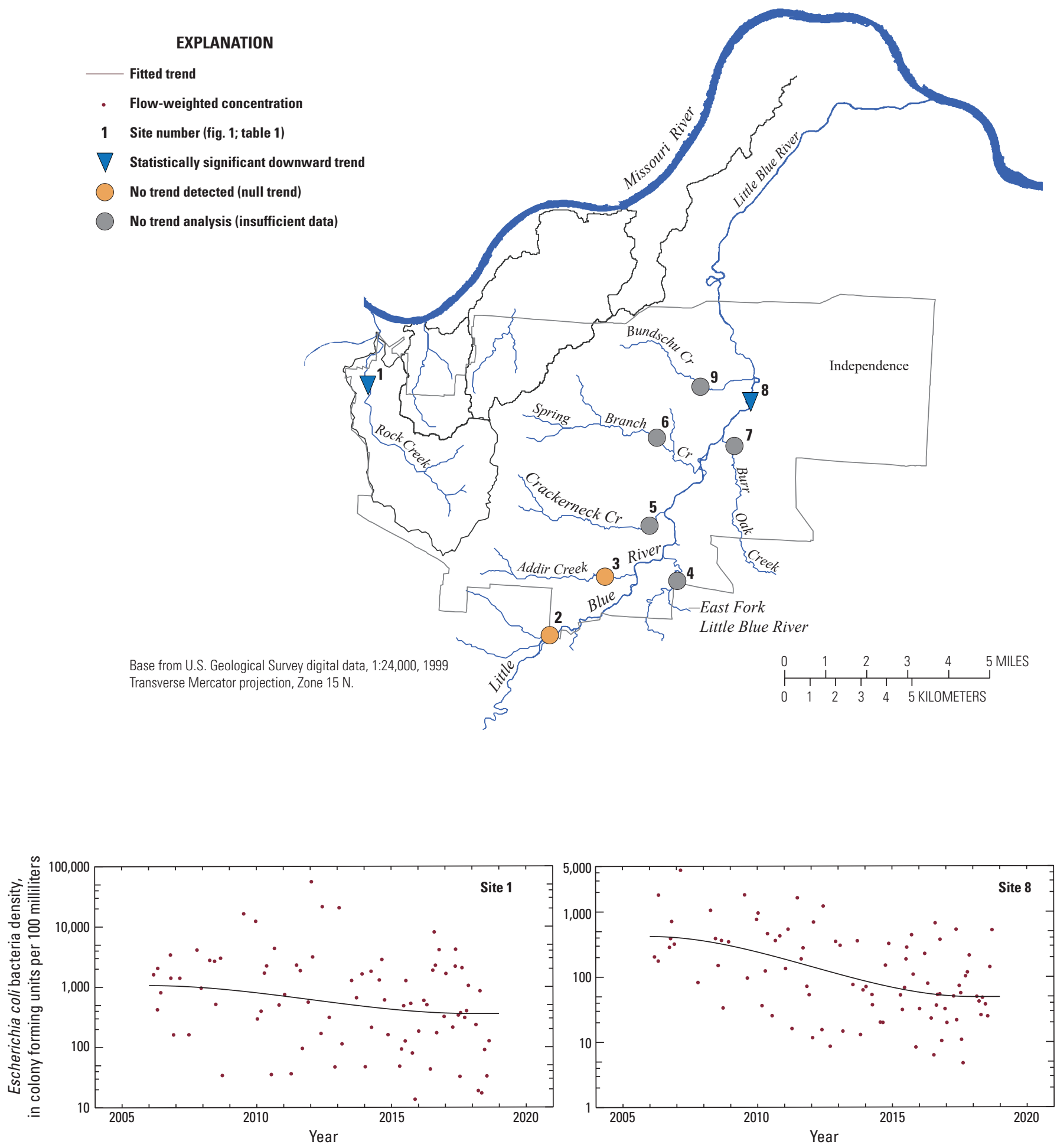

Figure 14. Location map and graphs of sites with statistically significant trends in flow-weighted Escherichia coli bacteria densities from 2006 through 2018. 


\section{Trends in Suspended-Sediment Concentrations and Loads}

Sediment is noted as one of the most common pollutants in streams across the Nation, causing damage to aquatic habitat as well as drinking water and recreational issues (U.S. Environmental Protection Agency, 2017). Sediment in suspension can be the primary pollutant or carry other pollutants such as nutrients, organic materials, pathogens, and trace elements. A statistically significant downward trend in SSC was identified at site 2 with a 63.1 percent change in annual flow-weighted mean concentration during the full period of available data (table 3). The downward trend in SSC at site 2 could be affected by the decreased streamflow and precipitation during the study period, by changes in sampling methods within the study period, and by the decrease in construction and urban land development upstream from the MS4 boundary.

No statistically significant change was indicated in the annual SSL transported from the Little Blue River near Lake City, Missouri (site 8) during the 2006-18 study period (table 5). However, with the exception of a dry 2006, annual SSLs at site 8 were about $80,000,000 \mathrm{~kg}$ or greater in the first 5 years of the study and were less than $82,000,000 \mathrm{~kg}$ during the last 8 years of the study (table 2.2). The annual mean SSL for site 8 was about $82,200,000 \mathrm{~kg}$ during the wetter period 1 (2006-10) and was about 55,700,000 kg during the drier period 2 (2011-18; table 7).

During period 2 (2011-18), the annual mean SSL transported from the Little Blue River at site 8 was about $55,700,000 \mathrm{~kg}$ (table 7). The combined annual mean SSL during period 2 transported from Spring Branch Creek (site 6) and Adair Creek (site 3) and potentially from other monitored and unmonitored streams in Independence that discharge into the Little Blue River was about 7,510,000 kg (table 7). This combined annual SSL mean is about 13 percent of the total SSL transported by the Little Blue River at site 8 . The Little Blue River upstream from Independence (site 2) and the upstream portion of the East Fork Little Blue River (site 4), contributed a combined mean annual SSL of about $33,500,000 \mathrm{~kg}$ during period 2; about 60 percent of the mean annual SSL in the Little Blue River at site 8 (55,716,374; table 7). Suspendedsediment yield from the East Fork Little Blue River at site 4 was an order of magnitude less than from the Little Blue River at site 2 (table 2.2). About an additional 3,740,000 kg (1,520 kilograms per hectare) of sediment were transported from Independence by Rock Creek (site 1) during period 2 (table 7).

\section{Observations in Concentrations by Land-Use and Water-Quality Criteria}

Select constituents were compared among six of the urban study sites to determine if the concentration distributions were statistically similar and to see how concentrations compared to State regulatory criteria and two agricultural sites (fig. 15). Data used in the comparison ranged from October 2005 through September 2018 to represent water years 2006 through 2018. A water year is the 12-month period from October 1 through September 30 and designated by the calendar year in which it ends. Sites 1, 2, 3, 4, 6, and 8 were included in the analyses, as well as two sites in predominantly agricultural watersheds in northern Missouri-Medicine Creek near Harris, Missouri (USGS site number 06899950) and Grand River near Sumner, Missouri USGS site number 06902000) (fig. 15; U.S. Geological Survey, 2019). These sites were chosen because they are in northern Missouri near the study area, have a different land use than the study area, and had monthly data available for the select constituents during the comparison period. The Medicine Creek site has a drainage area of $497 \mathrm{~km}^{2}$, which is similar to the area known as the Little Blue River within Independence. The Grand River site has a much larger drainage area $\left(17,800 \mathrm{~km}^{2}\right)$ than any of the urban streams, but the site was chosen because of its long period of nutrient data and because the site was part of a stormflow-event sampling project for suspended sediment. If constituent concentrations were not significantly different ( $p$-value less than 0.05 ), the sites were grouped by the same letter in figure 15, which were obtained by the Tukey's test. Some sites were grouped with more than one letter, indicating similar medians in concentrations among multiple sites. If one site had a unique letter, the site was statistically different from any other site.

The water quality of urban streams in Independence and two nearby agricultural rivers indicate many similarities. Median dissolved oxygen concentrations, water temperature, and $E$. coli densities were similar among all sites (fig. 15). Sites 1 and 3 had more statistically similar constituents among all the sites - mostly among the physical properties. Specific conductance, nitrate plus nitrite, and TN concentrations at site 1 were significantly different from other sites. Differences between urban and agriculture sites were that agricultural sites generally had lower water temperature, ammonia, and chloride median concentrations than the urban sites and had higher dissolved oxygen and SSC (only one agricultural comparison site had SSC data) median concentrations than the urban sites (fig. 15).

State and Federal regulatory requirement for the protection of aquatic life or human contact are shown in comparison with all available data in figure 15. The Clean Water Commission of the Missouri Department of Natural Resources implemented a minimum dissolved oxygen requirement of 5 milligrams per liter $(\mathrm{mg} / \mathrm{L})$ for waters designated as warmwater fishery, and water temperature maximum criteria of about 32.2 degrees Celsius (Missouri Department of Natural Resources, 2019a; fig. 15). The Little Blue River has been designated as a warm-water fishery stream as part of other provisional aquatic life limits. The State of Missouri falls within the EPA Region 7, which in 2005 established benchmark criteria for nutrients in regional streams (Missouri Department of Natural Resources, 2019b). These benchmarks are for TN 
(0.9 mg/L; fig. 15) and TP (0.075 mg/L; fig. 15). Additionally, the State also has standards for chloride $(230 \mathrm{mg} / \mathrm{L})$, which are part of the EPA concentration limits for chronic toxicity of aquatic life of (Missouri Department of Natural Resources, 2019a; fig. 15).

The Little Blue River and many of its tributaries that drain Independence have been designated as recreational waters classified for WBC-B and SCR. As a result of urban runoff and storm sewers, some of these designated streams have been listed as impaired for E. coli on the Missouri Department of Natural Resources 2018 Section 303(d) Listed Waters (Missouri Department of Natural Resources, 2018). Five streams_-Rock Creek, Spring Branch Creek, East Fork Little Blue River, Burr Oak Creek, and Little Blue Riverwere listed as impaired for $E$. coli in 2018. Geometric means of available samples during the recreational season (April through October) are greater than the regulatory colony density requirement of 206 colony forming units per 100 milliliters (CFU/100 mL) for WBC-B and 1,134 CFU/100 mL for SCR (fig. 15; Missouri Department of Natural Resources, 2019a). The geometric mean of all samples for the period of available data for each site is less than the SCR at sites 2, 3, 4, and 8 (fig. 15). Boxplots of E. coli population density (fig. 15) show similar (within one order of magnitude) medians and geometric means for the recreational season (April through October) and all available data for both Little Blue River sites (sites 2 and 8). The Little Blue River drainage area nearly doubles in size from site $2\left(254 \mathrm{~km}^{2}\right)$ to site $8\left(476 \mathrm{~km}^{2}\right.$; table 1); therefore, the consistent $E$. coli population densities at site 2 and 8 is primarily because of the increased volume of streamflow, which creates a dilution effect (fig. 15). It is possible that FIB may be settling out of suspension during transportation downstream and incubate in storage in streambed sediments. It is also possible that FIB have a high die-off rate during transportation downstream. The improvements to the city's MS4 wastewater and stormwater infrastructure, as well as the modifications to the sampling methods during the study period, also could have reduced FIB population density transported in the Little Blue River between the study sites. Specific sources of E. coli in the Little Blue River and its tributaries are currently (2019) unknown. Previous microbial source tracking investigations documented in Bushon and others (2017) characterized some sources within the Little Blue River and some of its tributaries during stormwater runoff collected from June 2008 through October 2014 from human, canine, and ruminant markers. 

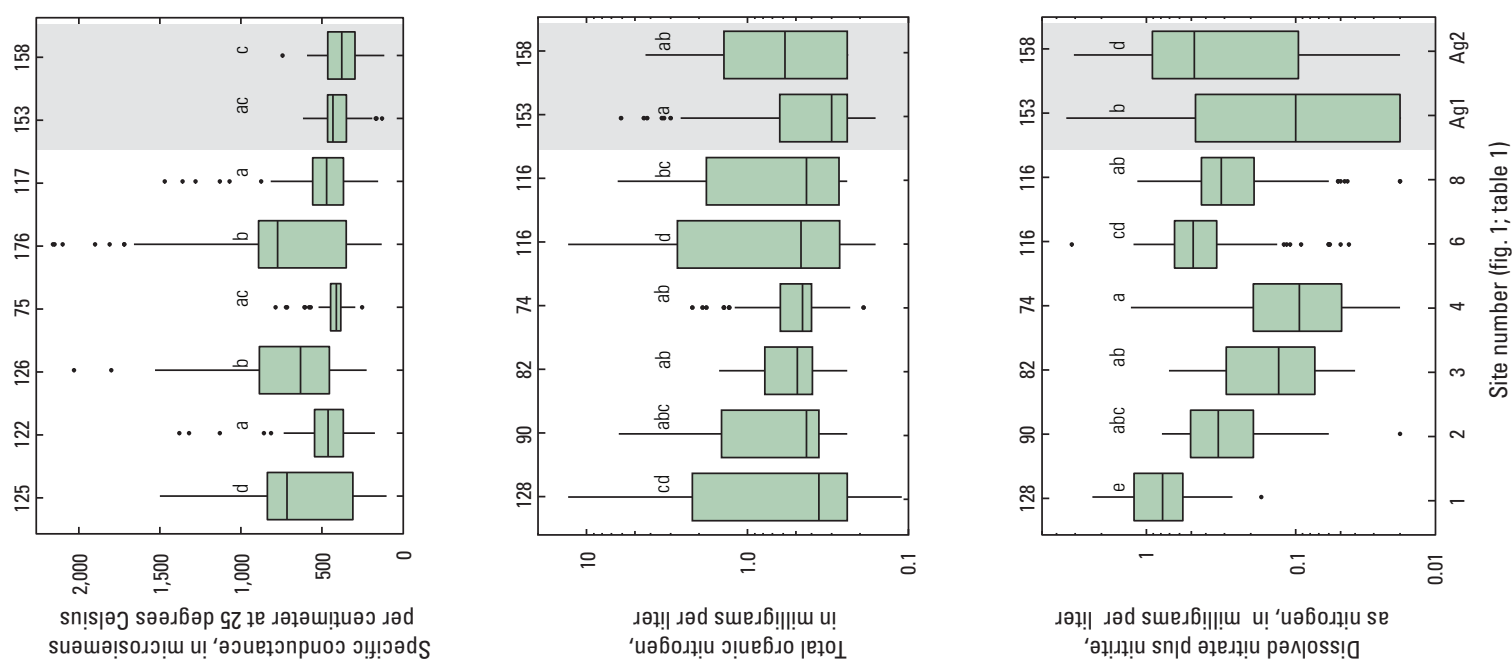

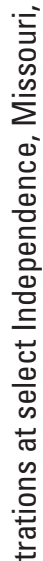

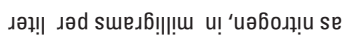

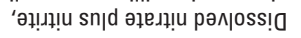
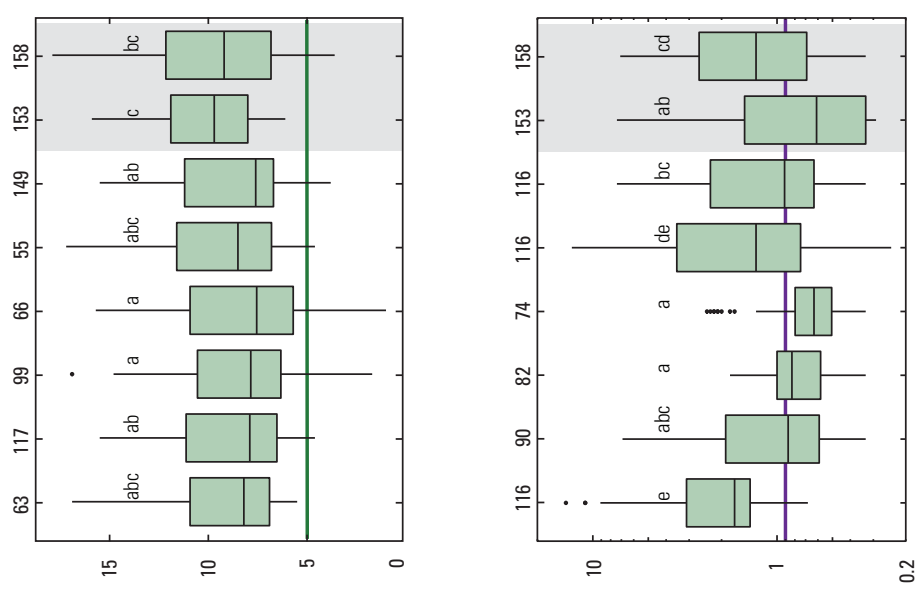

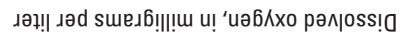

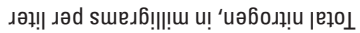

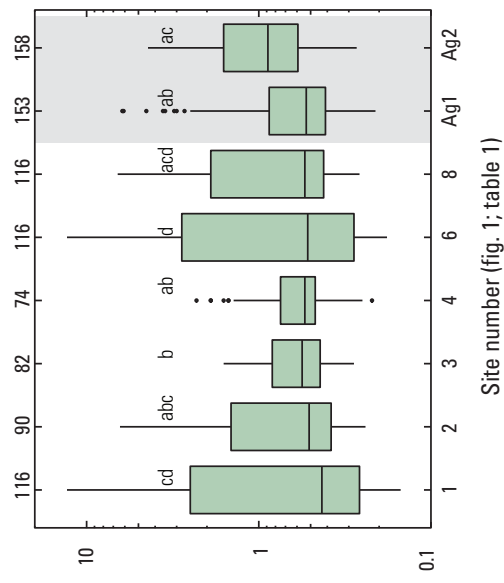

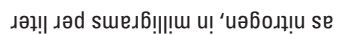

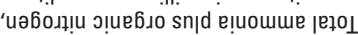

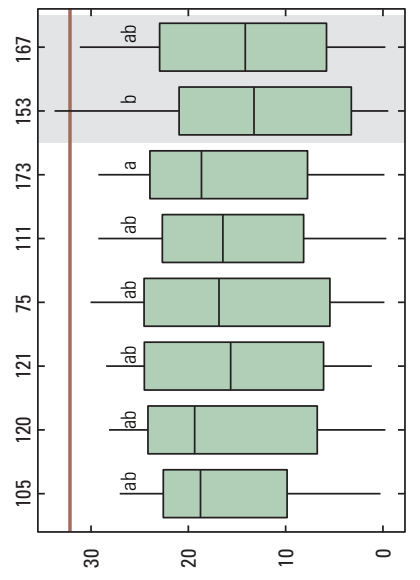

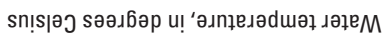

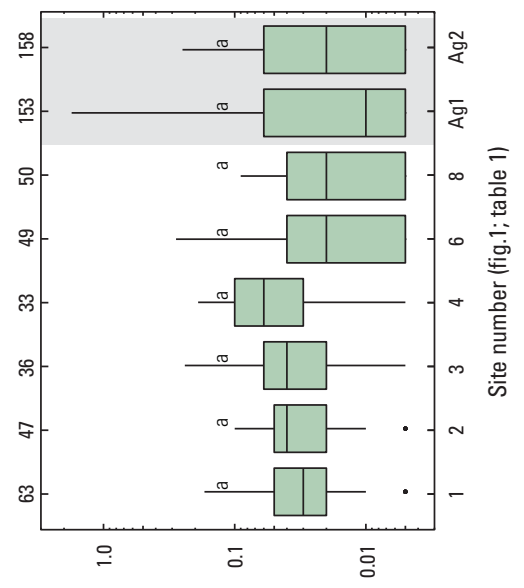

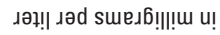

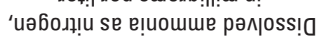




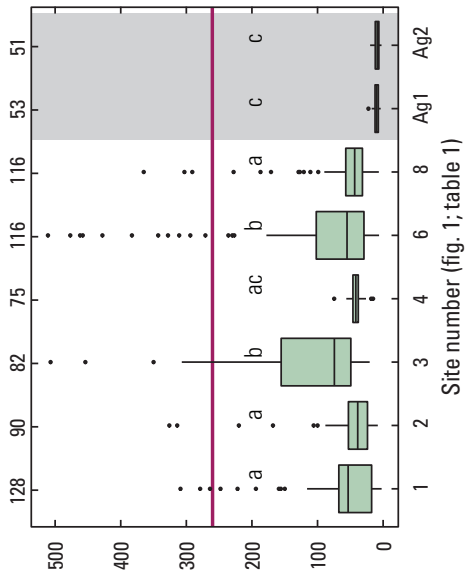

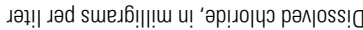

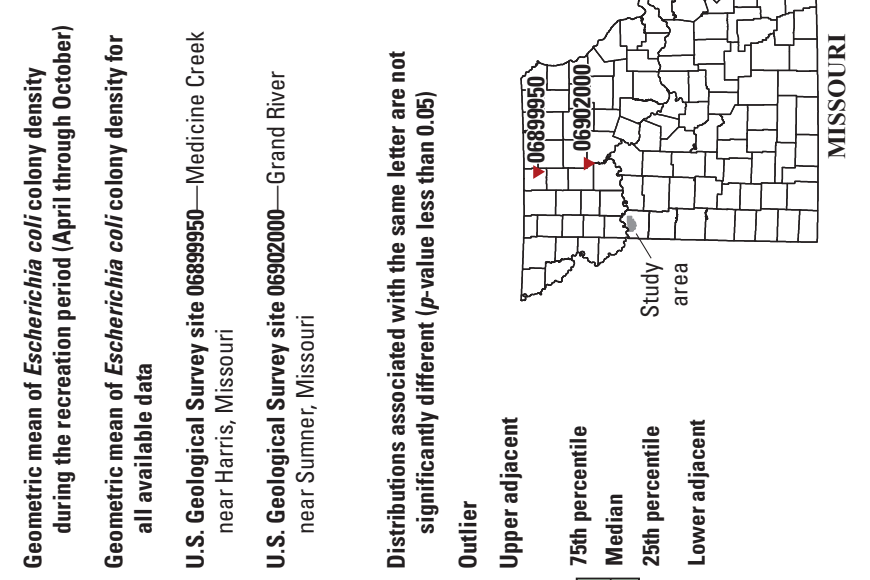

은
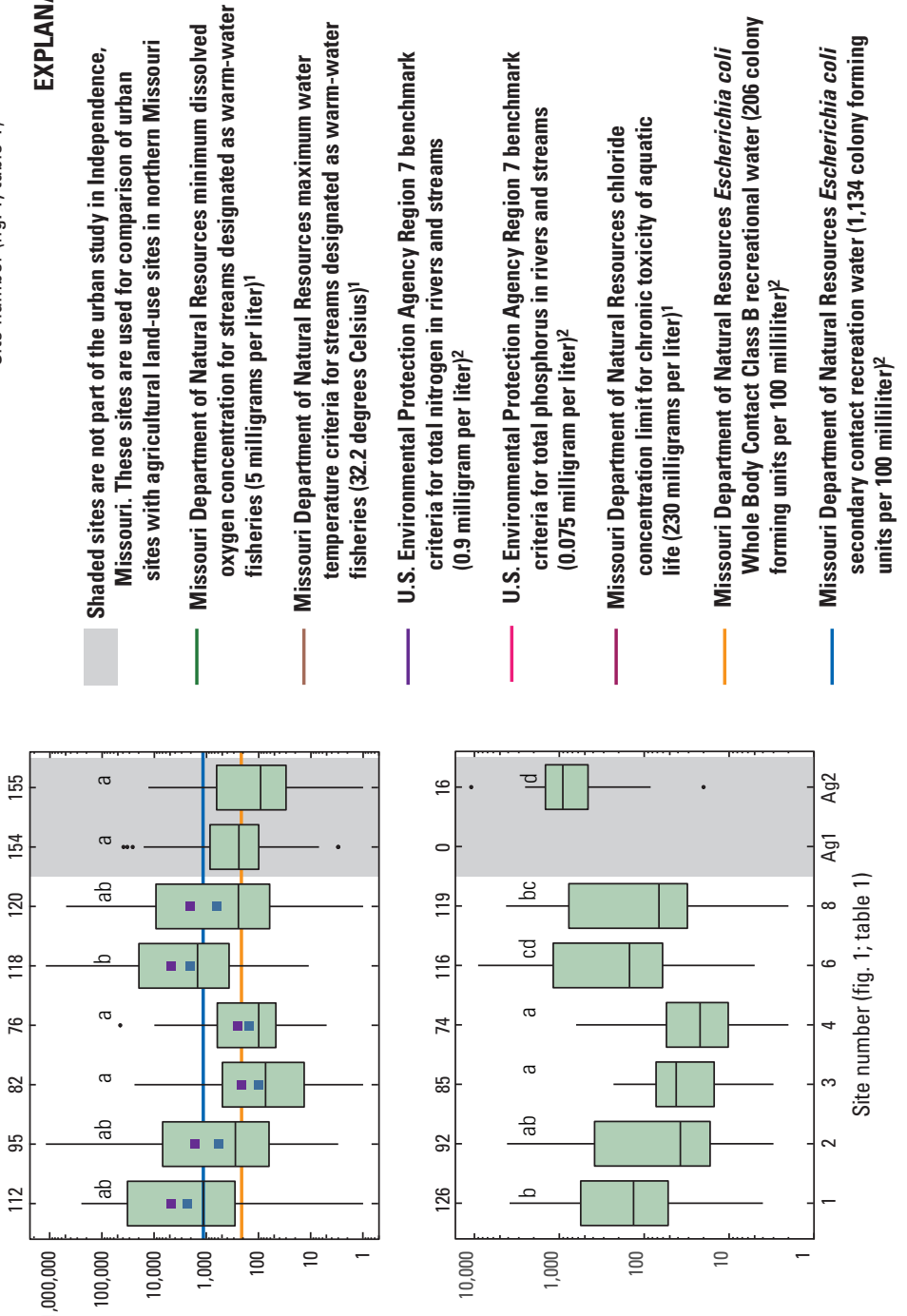

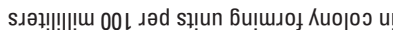
!| एо е!पग!.

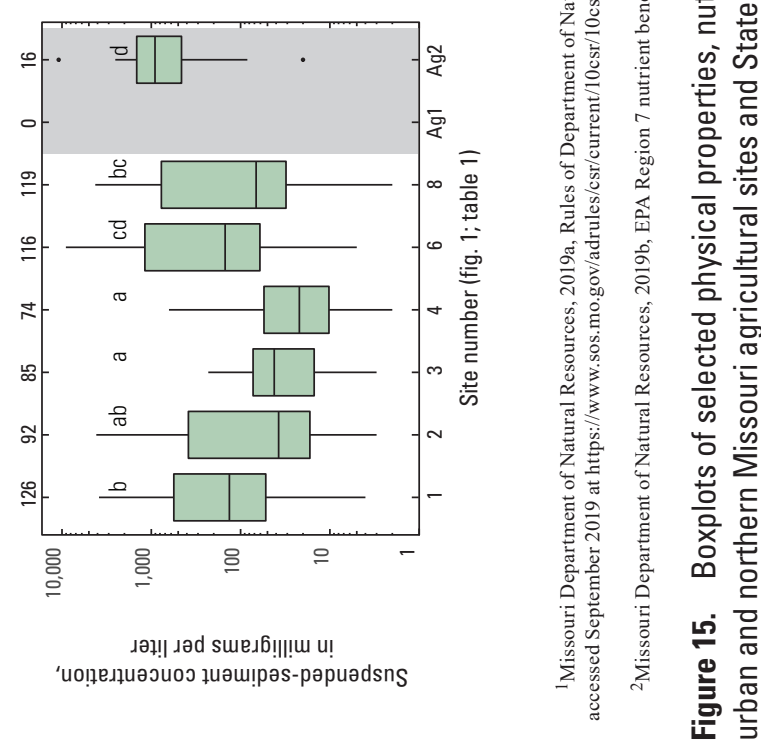




\section{Summary and Conclusions}

The U.S. Geological Survey and the city of Independence, Missouri, Water Pollution Control Department began a cooperative study in June 2005 that continued through 2018 to characterize and evaluate the water quality and ecological condition of urban streams within Independence. Collection of water-quality data has resulted in a dataset that can be used to evaluate the progress of applied best management practices and to establish a baseline by which the effectiveness of current (2019) and future best management practices can be measured. This report presents trends in water quality in relation to changes in precipitation, streamflow, population, and land use among urban streams using data collected by U.S. Geological Survey staff from 2005 through 2018. Selected physical properties, nutrients, chloride, fecal indicator bacteria [FIB; such as Escherichia coli (E. coli) and total coliform], total dissolved solids (TDS), and suspended-sediment concentration (SSC) data for base-flow and stormflow samples were used to document temporal trends in concentrations and flow-weighted concentrations; and annual loads were computed and investigated for selected nutrients, chloride, and suspended sediment.

The Little Blue River drains a watershed of 580 square kilometers $\left(\mathrm{km}^{2}\right)$, of which about $160 \mathrm{~km}^{2}$, or roughly 28 percent, is within Independence, and flows generally northward, discharging into the Missouri River. The Little Blue River within Independence is monitored as part of the city's municipal separate storm sewer system at two sites: upstream from the city and downstream from three of its tributaries. The largest tributary to the Little Blue River is the East Fork Little Blue River. Adair Creek and Spring Branch Creek also are tributaries that drain Independence. An additional study site is located on Rock Creek, which is not a tributary of the Little Blue River, but drains the northwest portion of the city to the Missouri River. The Little Blue River is regulated with the State of Missouri as a metropolitan no discharge stream, meaning no municipal effluent can be directly discharged into the stream.

Population and land use in the study area indicated no significant changes during the study. However, results indicated differences in precipitation and streamflow, which were identified as two periods within the study - period 1 (2006-10) and period 2 (2011-18). Slightly lower air temperatures and more precipitation probably were contributing factors that resulted in greater annual streamflow in the Little Blue River during the first period (2006-10) than in the second period (2011-18). The differences in annual precipitation and streamflow between the two periods also were identified in trends of annual loads of some constituents.

Trends in the measurements of physical properties; the concentrations of total and dissolved nutrients, dissolved chloride, total dissolved solids, and suspended sediment; and population densities of FIB were investigated at four urban stream sites. The concentration trends were performed using a statistical time-series modeling package developed by the U.S. Geological Survey called R-QWTREND, and has the ability to model serial correlation among observations, and can model complex trends during different times as well as different directions. Annual loads of selected nutrients, dissolved chloride, and suspended sediment were estimated using the Weighted Regressions on Time, Discharge, and SeasonKalman filter (WRTDS-K) model at six urban stream sites. Both R-QWTREND and WRTDS-K are publicly available software packages written in $\mathrm{R}$, a free, open-source language used for statistical and graphical interpretations and computations. Trend analysis datasets for both concentration and load trends contained samples collected from January 2006 through December 2018.

Statistically significant trends in flow-weighted nutrient concentrations generally were downward during the study period. A statistically significant downward trend in flowweighted total nitrogen concentration was indicated at all four sites, and the Rock Creek site had the highest concentrations. Flow-weighted concentrations of total organic nitrogen were indicated as statistically significant downward trends at all sites except the Adair Creek site. Downward trends also were identified at the Rock Creek site and the upstream site on the Little Blue River for total ammonia plus organic nitrogen as nitrogen; and one statistically significant downward trend was identified in flow-weighted concentrations of dissolved nitrate plus nitrite as nitrogen. Downward total phosphorus trends were statistically significant at the Rock Creek site and the downstream site on the Little Blue River. The downward trend in annual flow-weighted nutrient concentrations could be from a change in sampling program from a targeted stormwater collection effort to a more hydrologically diverse sampling program or from improvements to storm and wastewater infrastructure within the various watersheds within the city, or both. The only nutrient compound with a statistically significant upward trend was dissolved orthophosphate as phosphorus. This upward trend was indicated at the Rock Creek site and the upstream site on the Little Blue River.

The only statistically significant trend in annual loads of nitrogen species was identified for dissolved ammonia transported from the Little Blue River watershed at the downstream Little Blue River site. Although there was a significant downward linear trend, ammonia made up the smallest part of the total nitrogen load transported from Independence in the Little Blue River. Independence contributed a mean of 43 percent of the total nitrogen, 41 percent of the total organic nitrogen, 34 percent of the nitrate plus nitrite as nitrogen, and 15 percent of the dissolved ammonia load identified at the Little Blue River downstream site. The total nitrogen load decreased from period 1 (2006-10) to period $2(2011-18)$ at all six sites for all nitrogen species except dissolved ammonia at the Adair Creek site.

As with nitrogen, there were nonstatistically significant decreases in the loads of total phosphorus and orthophosphate as phosphorus transported from the Little Blue River and its tributaries from 2006 through 2018. The downward trends were caused by reduced streamflow during study period 2 (2011-18) that are reflected in larger period-1 annual loads compared to period-2 mean annual loads. An exception to the 
overall downward trends in nutrient transport was a significant upward linear trend in annual orthophosphate as phosphorus load at the Adair Creek site, which increased from less than $100 \mathrm{~kg}$ in 2009 to more than $200 \mathrm{~kg}$ in 2017. Overall, the total phosphorus transported to the Little Blue River from the city of Independence constituted about 57 percent of the annual total phosphorus load at the downstream Little Blue River site during the 2011-18 period.

A statistically significant upward trend in dissolved chloride concentrations was identified at the downstream Little Blue River site. The annual flow-weighted mean concentrations increased by about 41 percent from 2006 through 2018. Land-use changes indicate small increases (about 1 percent or less) in developed low-, medium-, and high-intensity; however, increased road salt application near the site during the winter could have resulted in higher concentrated runoff during wet weather conditions.

Annual chloride loads significantly decreased at the Adair Creek and Spring Branch Creek sites during the study period. The decrease in chloride load at the two sites was nearly half from the wetter period 1 (2006-10) to the drier (2011-18) period 2. Annual chloride loads at site 6 decreased from $929,763 \mathrm{~kg}$ in 2007 to $166,184 \mathrm{~kg}$ in 2018 . The mean annual chloride load transported in the drier period 2 was significantly less than during the wetter period 1, indicating that trends in precipitation runoff are an important factor in trends in annual transport of chloride. For the study period, samples were collected primarily during the recreational period (April through October) until 2014; limited data were available during the winter (November to February) when road salt application typically occurs.

Statistically significant downward trends in FIB E. coli population densities were noted for the Rock Creek site and the downstream site on the Little Blue River. The annual geometric mean concentration of $E$. coli population density decreased during the trend period, but the flow-weighted annual mean population density increased from 2006 through 2018 for the two sites. The changes in data collection methodology during the period of record could have affected the annual flow-weighted mean densities because samples were collected primarily during stormflow events for most of the study (2006-13). Since 2014, samples were collected with more temporal and spatial variance to gain more data within various streamflow conditions, which also increased the number of samples per year. The downward trends in FIB population densities could also be a result of improvements within the MS4 to stormwater and wastewater infrastructure, particularly for the Rock Creek site.

The E. coli densities at both Little Blue River sites supports conclusions in previous studies that FIB concentrations were not significantly different from upstream to downstream from the MS4 area and have remained unchanged during the study period. No trend was indicated in E. coli population density at the upstream site on the Little Blue River, but a statistically significant downward trend was identified at the downstream site on the Little Blue River. The change in E. coli density downstream could be a result of dilution from increased streamflow volume downstream, a decrease in streamflow and precipitation during the study period, storage of FIB in the Little Blue River streambed within the study area, die-off of FIB during travel from upstream to downstream changes in the sample collection methodology, improvements to the MS4 stormwater and wastewater infrastructures, or a combination of these factors.

A statistically significant downward trend in suspendedsediment concentration was identified at the upstream Little Blue River site with a 63.1 percent change during the study period. This trend could be affected by the decreased streamflow and precipitation during the study period, by changes in sampling methods within the study period, and by the decrease in construction and urban land development upstream from the city.

No statistically significant change was indicated in the annual suspended-sediment load (SSL) transported from the Little Blue River during the 2006-18 study period. With the exception of a dry 2006, the annual mean SSL at the downstream Little Blue River site during the first 5 years of the study was greater than the annual mean SSL during the last 8 years of the study. The annual mean SSL transported from the Little Blue River at the downstream site was about 82,200,000 kg during the wetter period 1 (2006-10) and was about 55,700,000 kilograms during period 2 (2011-18). About 13 percent of the total SSL transported in the Little Blue was transported from Spring Branch Creek and Adair Creek. About 60 percent of the total upstream contribution during period 2 (2011-18) originated in the Little Blue River watershed upstream from Independence.

The Little Blue River and many of its tributaries that drain Independence have been designated as recreational waters classified for whole-body contact class B and secondary contact recreation, and some of these designated streams have been listed as impaired for E. coli by the Missouri Department of Natural Resources from urban runoff and storm sewers. Observations were made among the available $E$. coli population density data for both Little Blue River sites to further understand water-quality conditions over the study period. Both Little Blue River sites had similar medians and geometric means for the recreational season (April through October) and for all available data during the study period, both of which are greater than the regulatory population density for both recreational classes. The Little Blue River drainage area nearly doubles in size from the upstream site $\left(254 \mathrm{~km}^{2}\right)$ to the downstream site $\left(476 \mathrm{~km}^{2}\right)$; therefore, the consistent $E$. coli population densities at the upstream and downstream Little Blue River sites is primarily because of the larger volume of streamflow, which creates a dilution effect. Other possible factors include storage of FIB in streambed sediments, die-off of FIB during transport, improvements to the city's wastewater and stormwater infrastructure, the changes to sampling methodology, or a combination of these factors. Specific sources of the E. coli are currently (2019) unknown. Previous microbial source tracking investigations characterized E. coli sources within the Little Blue River and 
some of its tributaries during stormwater runoff collected from June 2008 through October 2014 from human, canine, and ruminant markers.

Climate changes, particularly precipitation and streamflow conditions, contributed to the changes identified in the concentrations of nutrients, chloride, fecal indicator bacteria, and sediment as well as the constituent loads transported in urban streams. During the full study period, annual streamflow for period 2 (2011-18) was about 30 percent less than for period 1 (2006-10). This result is reflected in the smaller nutrient, dissolved chloride, and SSLs transported from the urban streams and from the Little Blue River. The amount of developed land and the population in the Independence urban watersheds remained unchanged during the 2006-18 study period and, thus, had little effect on the downward trend in transport.

Changes in data collection methodology during the study period and improvements to the city stormwater and wastewater infrastructure could also have contributed to some of the identified trends. Stormflow events were targeted with limited base-flow samples in the first period, with more samples collected annually across various streamflow conditions as well as seasons in the second period. For both periods, samples were collected during the recreational season from April through October, with limited samples collected during the winter. Between 2009 and 2015, more than 35 million dollars of improvements were made to stormwater and wastewater infrastructure within the city. These improvements, such as additional sewage overflow holding tanks, removal of septic tanks, and improved and expanded sanitary sewer lines and storm overflows, also could have resulted in the downward nutrients and FIB trends among the urban streams in the study area.

\section{References Cited}

Bushon, R.N., Brady, A.M.G., Christensen, E.D., and Stelzer, E.A., 2017, Multi-year microbial source tracking study characterizing fecal contamination in an urban watershed: Water Environment Research, v. 89, no. 2, p. 127-143. [Also available at https://doi.org/10.2175/ 106143016X14798353399412.]

Christensen, E.D., Harris, T.E., and Niesen, S.L., 2010, Water quality and ecological condition of urban streams in Independence, Missouri, June 2005 through December 2008: U.S. Geological Survey Scientific Investigations Report 2010-5074, 115 p. [Also available at https://doi.org/ 10.3133/sir20105074.]
Christensen, E.D., and Krempa, H.M., 2013, Assessment of macroinvertebrate communities in adjacent urban stream basins, Kansas City, Missouri, metropolitan area, 2007 through 2011: U.S. Geological Survey Scientific Investigation Report 2012-5284, 45 p. [Also available at https://doi. org/10.3133/sir20125284.]

Ellis, J.T., 2018, Missouri StreamStats-A water-resources web application: U.S. Geological Survey Fact Sheet 2018-3003, 6 p., https://doi.org/10.3133/fs20183003.

Heimann, D.C., 1995, Physical, chemical, and biological characteristics of three reservoirs in west-central Missouri, 1991-93: U.S. Geological Survey Water-Resources Investigations Report 95-4120, 114 p. [Also available at https:// doi.org/10.3133/wri954120.]

Helsel, D.R., Hirsch, R.M., Ryberg, K.R., Archfield, S.A., and Gilroy, E.J., 2020, Statistical methods in water resources: U.S. Geological Survey Techniques and Methods, book 4, chap. A3, 458 p. [Also available at https://doi.org/10.3133/ tm4a3.]

Hirsch, R.M., and De Cicco, L.A., 2015, User guide to Exploration and Graphics for RivEr Trends (EGRET) and dataRetrieval — R packages for hydrologic data (version 2.0, February 2015): U.S. Geological Survey Techniques and Methods, book 4, chap. A10, 93 p. [Also available at https:// doi.org/10.3133/tm4A10.]

Hobbie, S.E., Finlay, J.C., Janke, B.D., Nidzgorski, D.A., Millet, D.B., and Baker, L.A., 2017, Contrasting nitrogen and phosphorus budgets in urban watersheds and implications for managing urban water pollution: Proceedings of the National Academy of Sciences of the United States of America, v. 114, no. 16, p. 4177-4182, accessed December 4, 2019, at https://doi.org/10.1073/pnas.1618536114.

Jackson County Parks and Recreation, 2019, History of parks and lakes in Jackson County, Missouri: Jackson County Parks and Recreation website, accessed November 2, 2019, at https://www.makeyourdayhere.com/247/History.

Kelly, W.R., Panno, S.V., Hackley, K.C., Hwang, H.-H., Martinsek, A.T., and Markus, M., 2010, Using chloride and other ions to trace sewage and road salt in the Illinois waterway: Applied Geochemistry, v. 25, no. 5, p. 661-673. [Also available at https://doi.org/10.1016/ j.apgeochem.2010.01.020.]

Lee, C.J., Hirsch, R.M., and Crawford, C.G., 2019, An evaluation of methods for computing annual water-quality loads: U.S. Geological Survey Scientific Investigations Report 2019-5084, 59 p. [Also available at https://doi.org/10.3133/ $\operatorname{sir} 20195084$. 
Mallin, M.A., Williams, K.E., Esham, E.C., and Lowe, R.P., 2000, Effect of human development on bacteriological water quality in coastal watersheds: Ecological Applications, v. 10, no. 4, p. 1047-1056, accessed April 2, 2020, at https://doi.org/10.1890/1051-0761(2000)010[1047:EOHDO $\mathrm{B}] 2.0 . \mathrm{CO} ; 2$.

Midwestern Regional Climate Center, 2019, State and climate division data: assessed June 2019 at https://mrcc.illinois. edu/CLIMATE/nClimDiv/STCD_monthly1.jsp.

Missouri Department of Natural Resources, 2018, Missouri integrated water quality report and section 303(d) list, 2018, Clean Water Act sections 303(d), 305(b), and 314: Missouri Department of Natural Resources Water Protection Program, 209 p., accessed August 9, 2019, at https://dnr. mo.gov/env/wpp/waterquality/303d/303d.htm.

Missouri Department of Natural Resources, 2019a, Rules of Department of Natural Resources, Division 20-Clean Water Commission, Chapter 7-Water quality: Missouri Department of Natural Resources, Code of State Regulations, 10 CSR 20-7, p. 54-131, accessed September 2019 at https://www.sos.mo.gov/adrules/csr/current/10csr/10csr. asp\#10-20.

Missouri Department of Natural Resources, 2019b, EPA Region 7 nutrient benchmarks - Streams: accessed November 13, 2019, at https://dnr.mo.gov/env/wpp/wqstandards/ docs/rtag_region7_benchmarks.pdf.

Multi-Resolution Land Characteristics Consortium, 2020, National Land Cover Database, land cover and impervious products, accessed May 7, 2020, at https://www.mrlc.gov.

Niesen, S.L., and Christensen, E.D., 2015, Hydrological, water-quality, and ecological data for streams in Independence, Missouri, June 2005 through September 2013: U.S. Geological Survey Data Series 915, 80 p. [Also available at https://doi.org/10.3133/ds915.]

R Development Core Team, 2019, R-A language and environment for statistical computing: Vienna, Austria, R Foundation for Statistical Computing, accessed April 8, 2019, at https://www.r-project.org.

Rouse, K., 2004, Assessing urban wetlands (CD 997925010)_Final report to the U.S. Environmental Protection Agency, Region 7: Missouri Department of Natural Resources, Geologic Survey and Resource Assessment Division, Water Resources Program, 21 p., accessed June 2019 at https://dnr.mo.gov/geology/wrc/docs/urbanwetlands.pdf.
Runkel, R.L., Crawford, C.G., and Cohn, T.A., 2004, Load Estimator (LOADEST) - A FORTRAN program for estimating constituent loads in streams and rivers: U.S. Geological Survey Techniques and Methods book 4, chap. A5, 69 p. [Also available at https://doi.org/10.3133/tm4A5.]

Schalk, G.K., 1994, Quantity and quality of base flow and stormwater runoff in Independence, Missouri, October 1991 to February 1993: U.S. Geological Survey Open-File Report 93-495, 69 p. [Also available at https://doi.org/10.3133/ ofr93495.]

U.S. Census Bureau, 2020, City and town population totals, 2010-2018: U.S. Census Bureau website, accessed May 11, 2020, at https://www.census.gov/quickfacts/fact/table/ independencecitymissouri,US/PST045219.

U.S. Department of Justice, 2009, City of Independence, Missouri, agrees to major sewer system upgrades: U.S. Department of Justice, Office of Public Affairs, Environment and Natural Resources Division, Press release 09-289, accessed December 23, 2019, at https://www.justice.gov/opa/pr/ city-independence-missouri-agrees-major-sewer-systemupgrades.

U.S. Environmental Protection Agency, 1983, Results of the nationwide urban runoff program - Volume 1, final report: U.S. Environmental Protection Agency, Water Planning Division, accessed May 7, 2019, at https://www.epa.gov/ npdes/pubs/sw_nurp_vol_1_finalreport.pdf.

U.S. Environmental Protection Agency, 2017, National Water Quality Inventory-Report to Congress: U.S. Environmental Protection Agency, EPA 8441-R-16-011, 21 p., accessed August 2019 at https://www.epa.gov/waterdata/nationalwater-quality-inventory-report-congress.

U.S. Environmental Protection Agency, 2018, National pollutant discharge elimination system (NPDES)_-Applications and program updates: U.S. Federal Register, Title 40 of the CFR at Part 122, accessed August 9, 2019, at https://www. federalregister.gov/documents/2019/02/12/2019-01339/ national-pollutant-discharge-elimination-system-npdesapplications-and-program-updates.

U.S. Environmental Protection Agency, 2019, National aquatic resource surveys, Indicators-Phosphorus: U.S. Environmental Protection Agency web site: accessed November 19, 2019, at https://www.epa.gov/national-aquatic-resource-surveys/indicators-phosphorus.

U.S. Geological Survey, 2006, Collection of water samples (ver. 2.0): U.S. Geological Survey Techniques of Water Resources Investigations, book 9, chap. A4, 166 p. [Also available at https://doi.org/10.3133/twri09A4.] 
U.S. Geological Survey, 2019, USGS water data for the Nation: U.S. Geological Survey National Water Information System database, accessed April 14, 2020, at https://doi.org/ 10.5066/F7P55KJN.

Vecchia, A.V., 2000, Water-quality trend analysis and sampling design for the Souris River, Saskatchewan, North Dakota, and Manitoba: U.S. Geological Survey WaterResources Investigations Report 2000-4019, 77 p. [Also available at https://doi.org/10.3133/wri004019.]

Vecchia, A.V., 2005, Water-quality trend analysis and sampling design for streams in the Red River of the North Basin, Minnesota, North Dakota, and South Dakota, 1970-2001: U.S. Geological Survey Scientific Investigations Report 2005-5224, 54 p. [Also available at https://doi. org/10.3133/sir20055224.]

Vecchia, A.V., and Nustad, R.A., 2020, Time-series model, statistical methods, and software documentation for RQWTREND-An R package for analyzing trends in streamwater quality: U.S. Geological Survey Open-File Report 2020-1014, 51 p. [Also available at https://doi.org/10.3133/ ofr20201014.]
Yang, L., Jin, S., Danielson, P., Homer, C., Gass, L., Bender, S., Case, A., Costello, C., Dewitz, J., Fry, J., Funk, M., Granneman, B., Liknes, G., Rigge, M., and Xian, G., 2018, A new generation of the United States National Land Cover Database-Requirements, research priorities, design, and implementation strategies: ISPRS Journal of Photogrammetry and Remote Sensing, v. 146, p. 108123, accessed April 2, 2020, at https://doi.org/10.1016/ j.isprsjprs.2018.09.006.

Zhang, Q., and Hirsch, R.M., 2019, River water-quality concentration and flux estimation can be improved by accounting for serial correlation through an autoregressive model: Water Resources Research, v. 55, no. 11, p. 97059723, accessed November 2019 at https://doi.org/10.1029/ 2019WR025338. 
Appendixes 1-4 


\section{Appendix 1. Documentation of Concentration Trends for Urban Streams in Independence, Missouri, Analyzed Using R-OWTREND}

This appendix contains examples of the steps and processes used to analyze and produce flow-weighted trends in concentration data (available for download at https://doi.org/ 10/13133/sir20205130). A series of code (fig. 1.1A) using R software (R Development Team, 2019) shows an example of how all datasets were produced and prepared for use with R-QWTREND (Vecchia and Nustad, 2020). Additional code shows examples of how models were produced (fig. 1.1B) and the outputs of the results (fig. 1.2; table 1.1). Outliers that were identified and removed from datasets presented in the report also are documented (table 1.2). This appendix also contains an Excel spreadsheet of the summary statistics (table 1.3) for selected physical properties and chemical constituents at select sites in Independence, Missouri (available for download at https://doi.org/10/13133/sir20205130.

Table 1.1. Example of generic numerical model output of annual trend results (OWMODOUTANN) from R-OWTREND.

[dyr, decimal year for midpoint of calendar year; agmc, estimated annual geometric mean concentration, in milligrams per liter; tagmc, estimated trend in annual geometric mean concentration; fvrP10, 10th percentile of flow-related variability; fvr90, 90th percentile of the flow-related variability; amflow, annual mean streamflow, in cubic feet per second; afwac, annual flow-weighted average concentration, in milligrams per liter; tafwac, trend in annual flow-weighted average concentration; aflux, annual flux, in metric tons (1,000 kilograms) per day; taflux, trend in annual flux.]

\begin{tabular}{rlllllllll}
\hline dyr & agmc & tagmc & fruP10 & frvP90 & amflow & afwac & tafwac & aflux & taflux \\
\hline 2006.49 & 0.088 & 0.087 & 0.049 & 0.126 & 2.432 & 0.102 & 0.102 & 0.001 & 0.002 \\
2007.49 & 0.088 & 0.088 & 0.047 & 0.128 & 6.421 & 0.095 & 0.102 & 0.001 & 0.002 \\
2008.49 & 0.087 & 0.089 & 0.048 & 0.121 & 9.586 & 0.103 & 0.103 & 0.002 & 0.002 \\
2009.49 & 0.088 & 0.09 & 0.05 & 0.122 & 9.635 & 0.101 & 0.105 & 0.002 & 0.002 \\
2010.49 & 0.092 & 0.092 & 0.05 & 0.129 & 8.707 & 0.105 & 0.106 & 0.002 & 0.002 \\
2011.49 & 0.093 & 0.093 & 0.053 & 0.129 & 5.843 & 0.105 & 0.108 & 0.002 & 0.002 \\
2012.49 & 0.097 & 0.095 & 0.052 & 0.141 & 2.651 & 0.101 & 0.110 & 0.001 & 0.002 \\
2013.49 & 0.096 & 0.096 & 0.052 & 0.137 & 4.804 & 0.103 & 0.112 & 0.001 & 0.002 \\
2014.49 & 0.098 & 0.098 & 0.057 & 0.135 & 4.162 & 0.123 & 0.114 & 0.001 & 0.002 \\
2015.49 & 0.098 & 0.099 & 0.055 & 0.139 & 8.156 & 0.122 & 0.115 & 0.002 & 0.002 \\
2016.49 & 0.101 & 0.100 & 0.056 & 0.139 & 7.207 & 0.119 & 0.116 & 0.002 & 0.002 \\
2017.49 & 0.102 & 0.101 & 0.061 & 0.141 & 6.989 & 0.132 & 0.117 & 0.002 & 0.002 \\
2018.49 & 0.100 & 0.101 & 0.056 & 0.141 & 5.331 & 0.121 & 0.117 & 0.002 & 0.002 \\
\hline
\end{tabular}


Table 1.2. Outliers identified and removed from datasets during trend analysis of urban streams in Independence, Missouri, using ROWTREND.

[USGS, U.S. Geological Survey; site number in parenthesis was used for the study]

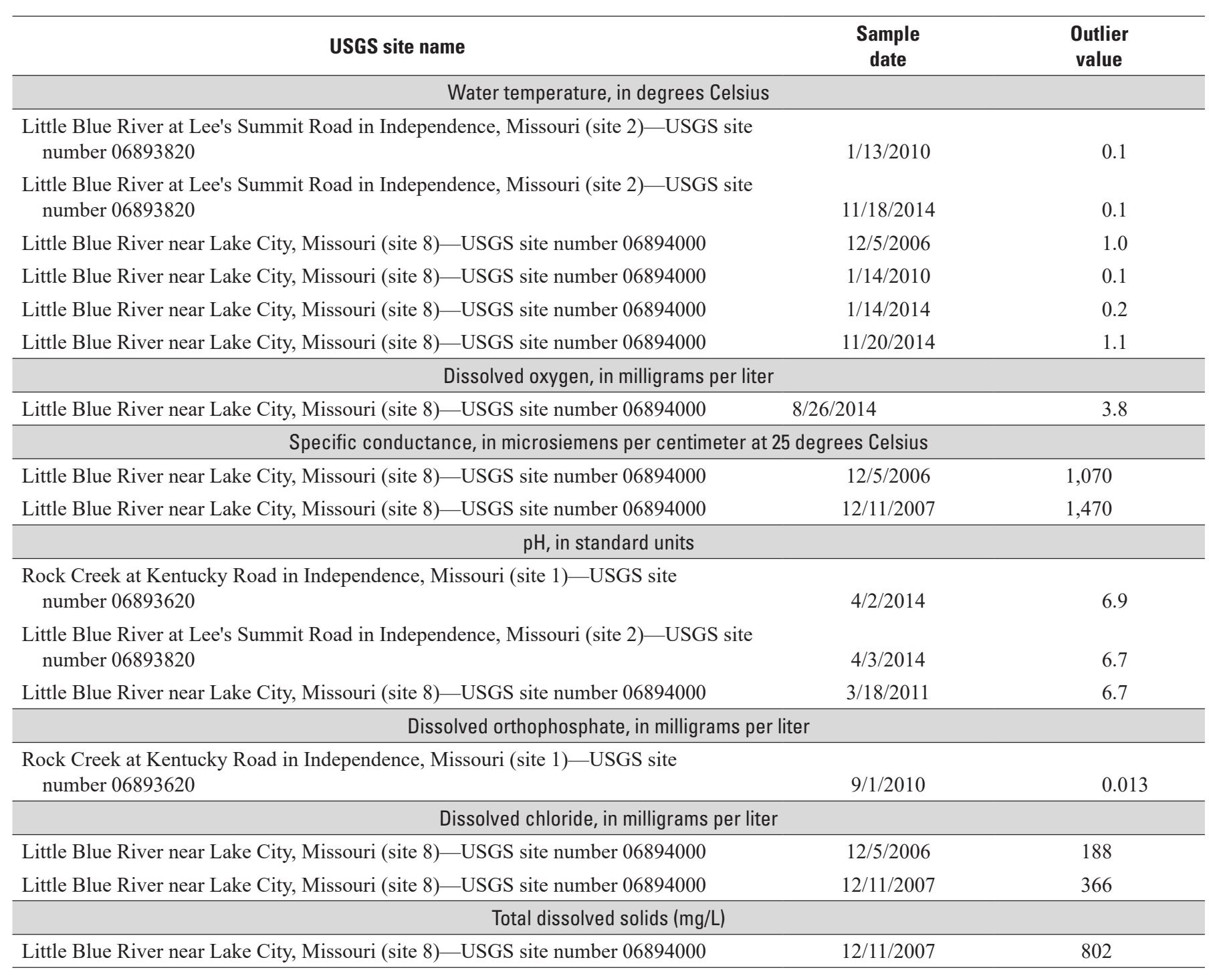




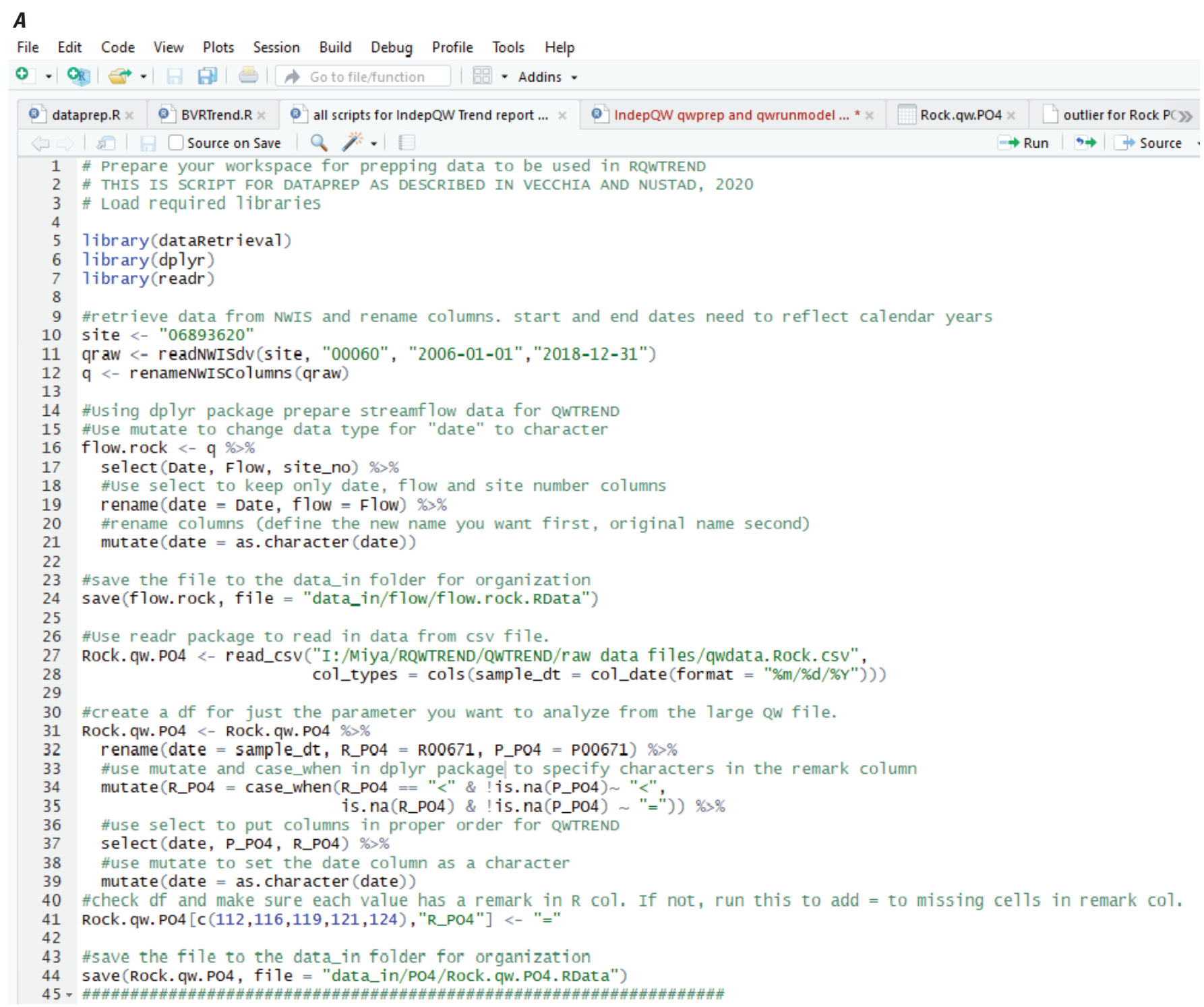

Figure 1.1. Script file containing series of code used with R-OWTREND. $A$, for creating a dataset; $B$, for setting up initial workspace and running R-OWTREND. 


\section{B} File Edit Code View Plots Session Build Debug Profile Tools Help

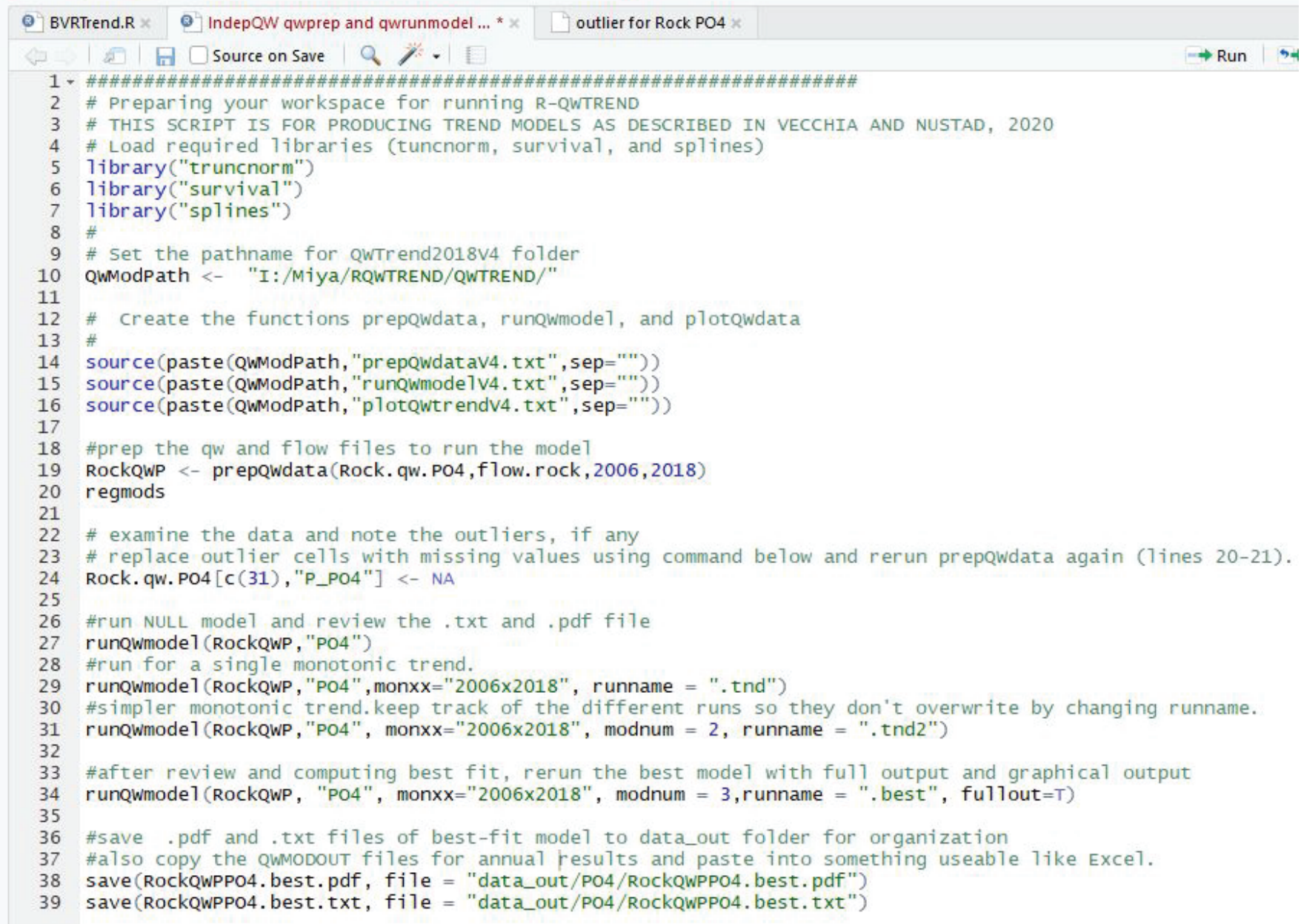

Figure 1.1. Script file containing series of code used with R-OWTREND. $A$, for creating a dataset; $B$, for setting up initial workspace and running R-QWTREND.-Continued 
$\boldsymbol{A}$

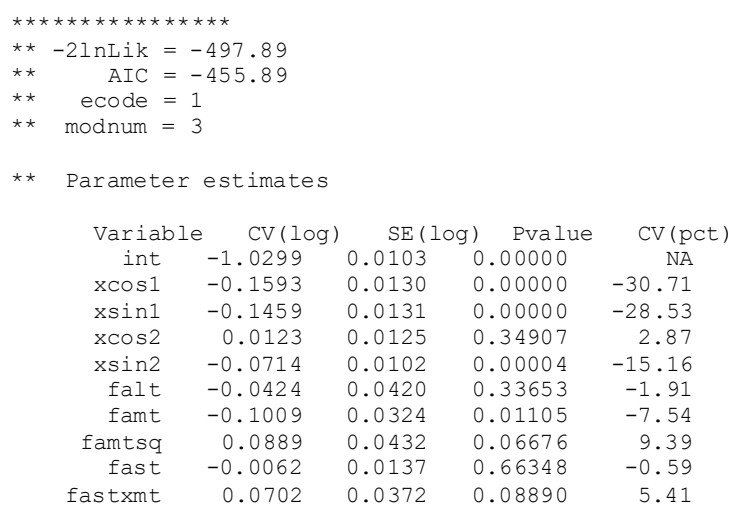

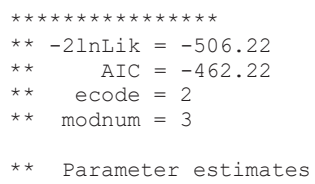

$\begin{array}{rrllr}\text { Variable } & \text { CV(log) } & \text { SE }(\text { log) } & \text { Pvalue } & \text { CV (pct) } \\ \text { int } & -1.0276 & 0.0095 & 0.00000 & \text { NA } \\ \text { xcos1 } & -0.1461 & 0.0126 & 0.00000 & -28.57 \\ \text { xsin1 } & -0.1487 & 0.0123 & 0.00000 & -28.99 \\ \text { xcos2 } & 0.0104 & 0.0115 & 0.38660 & 2.42 \\ \text { xsin2 } & -0.0761 & 0.0096 & 0.00001 & -16.07 \\ \text { falt } & -0.0095 & 0.0402 & 0.81738 & -0.43 \\ \text { famt } & -0.0565 & 0.0324 & 0.10881 & -4.29 \\ \text { famtsq } & 0.0297 & 0.0436 & 0.50932 & 3.04 \\ \text { fast } & 0.0022 & 0.0127 & 0.86864 & 0.21 \\ \text { fastxmt } & 0.0563 & 0.0339 & 0.12461 & 4.32 \\ \text { m2006x2018 } & 0.0619 & 0.0191 & 0.00789 & 15.32\end{array}$

\section{EXPLANATION}

[left, null model; right, single monotonic trend]

\author{
-2InLik-Minus two times the natural logarithm of the maximized likelihood function \\ AIC-Penalized likelihood value (not used in analysis) \\ ecode-Error code from nonlinear optimization program \\ modnum-Model number (Vecchia and Nustad, 2020) \\ CV(log)_Estimated coefficient value \\ SE(log)_Approximate standard error of estimated coefficient \\ Pvalue - Approximate probability value of coefficient \\ $\mathbf{C V}$ (pct)—Estimated coefficient value expressed as a percentage
}

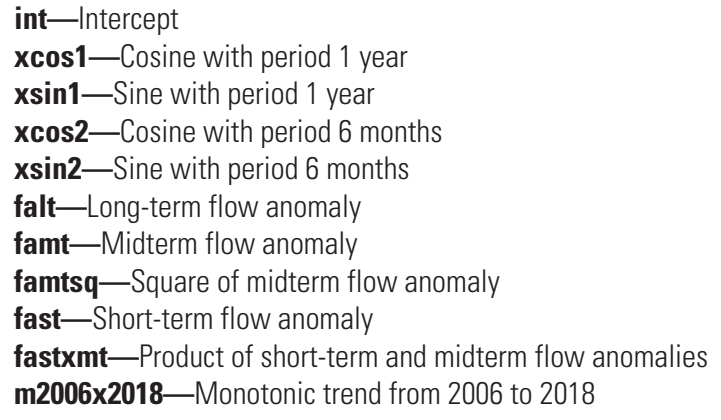

Figure 1.2. Output from run $Q W$ model for orthophosphate as phosphorus concentration data for the RockQWP dataset (fig. 1.1B) for a single monotonic trend $A$, maximum likelihood estimation results from text file; $B-K$, full graphical output. 


\section{RockQWPPO4.best.pdf}

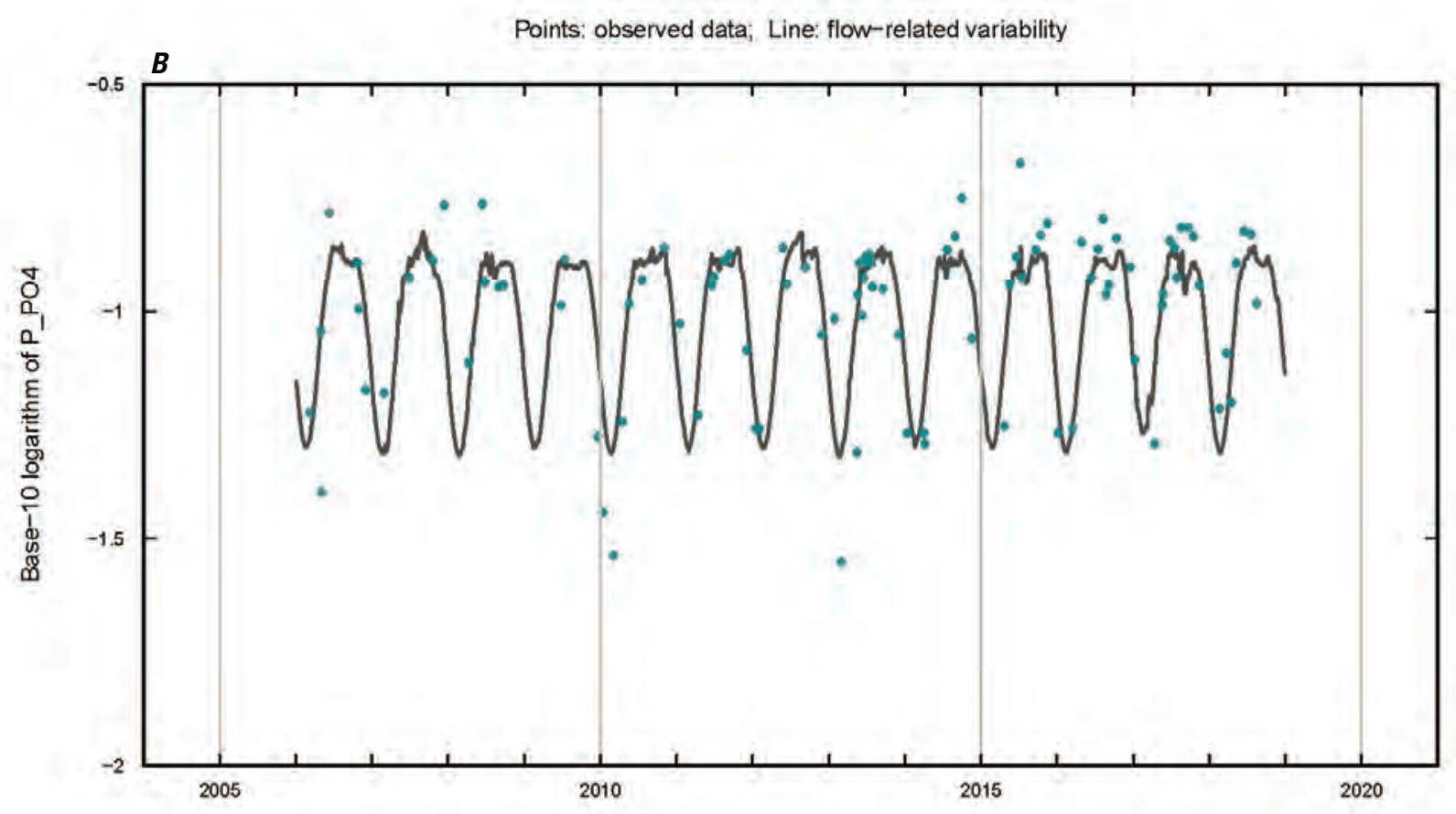

\section{RockQWPPO4.best.pdf}

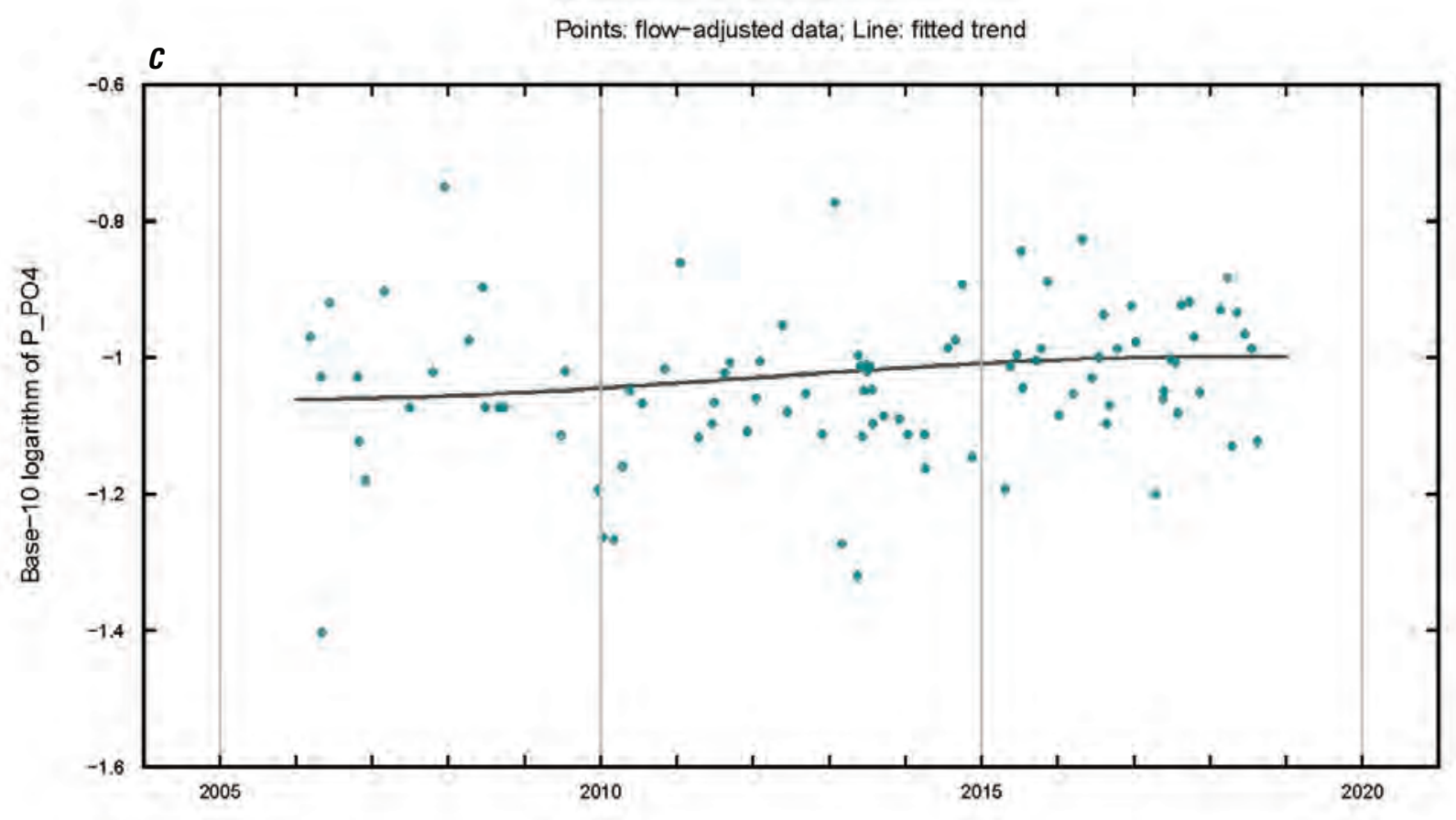

Figure 1.2. Output from run $Q W m o d e l$ for orthophosphate as phosphorus concentration data for the RockOWP dataset (fig. 1.1B) for a single monotonic trend $A$, maximum likelihood estimation results from text file; $B-K$, full graphical output.-Continued 


\section{RockQWPPO4.best.pdf}

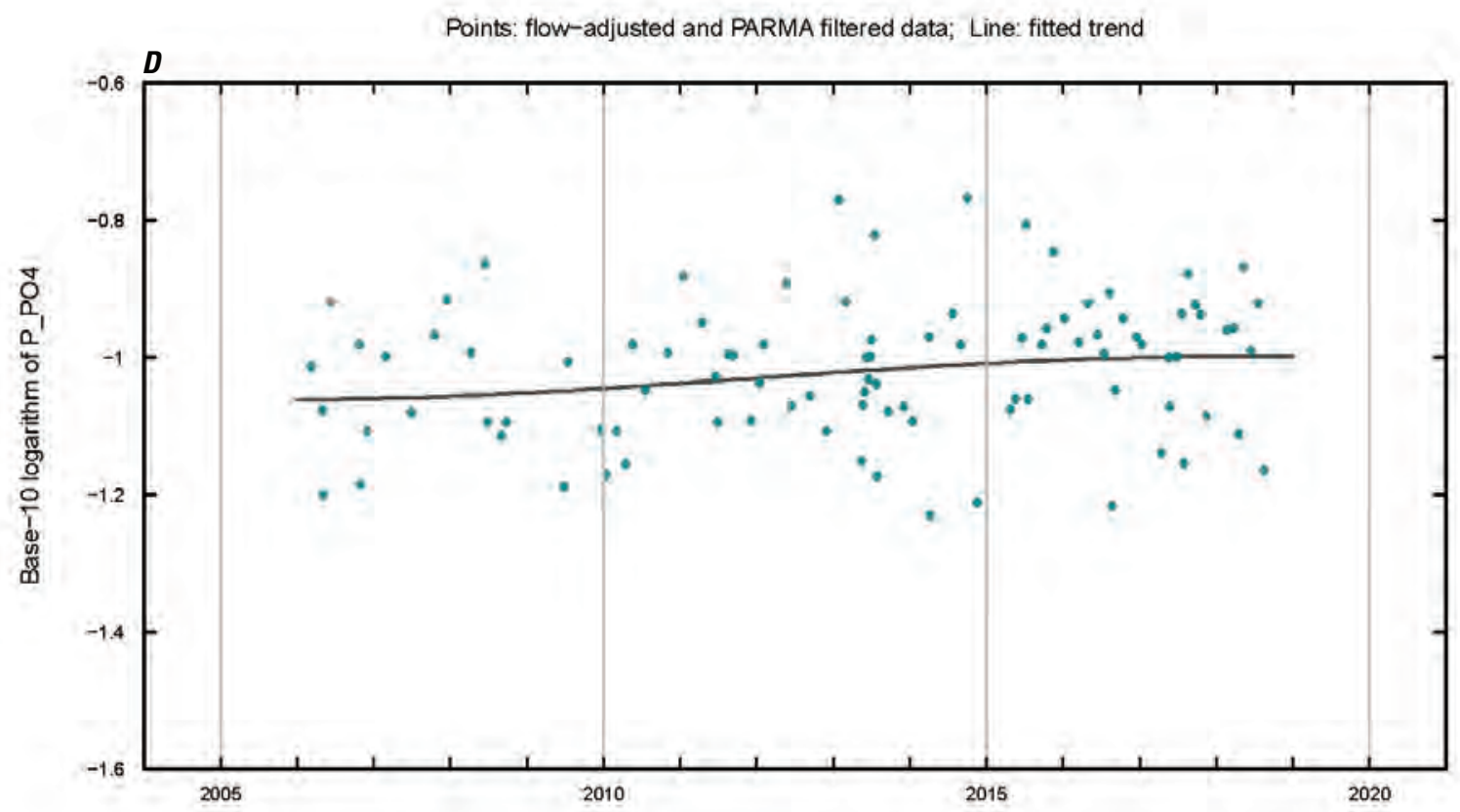

\section{RockQWPPO4.best.pdf}

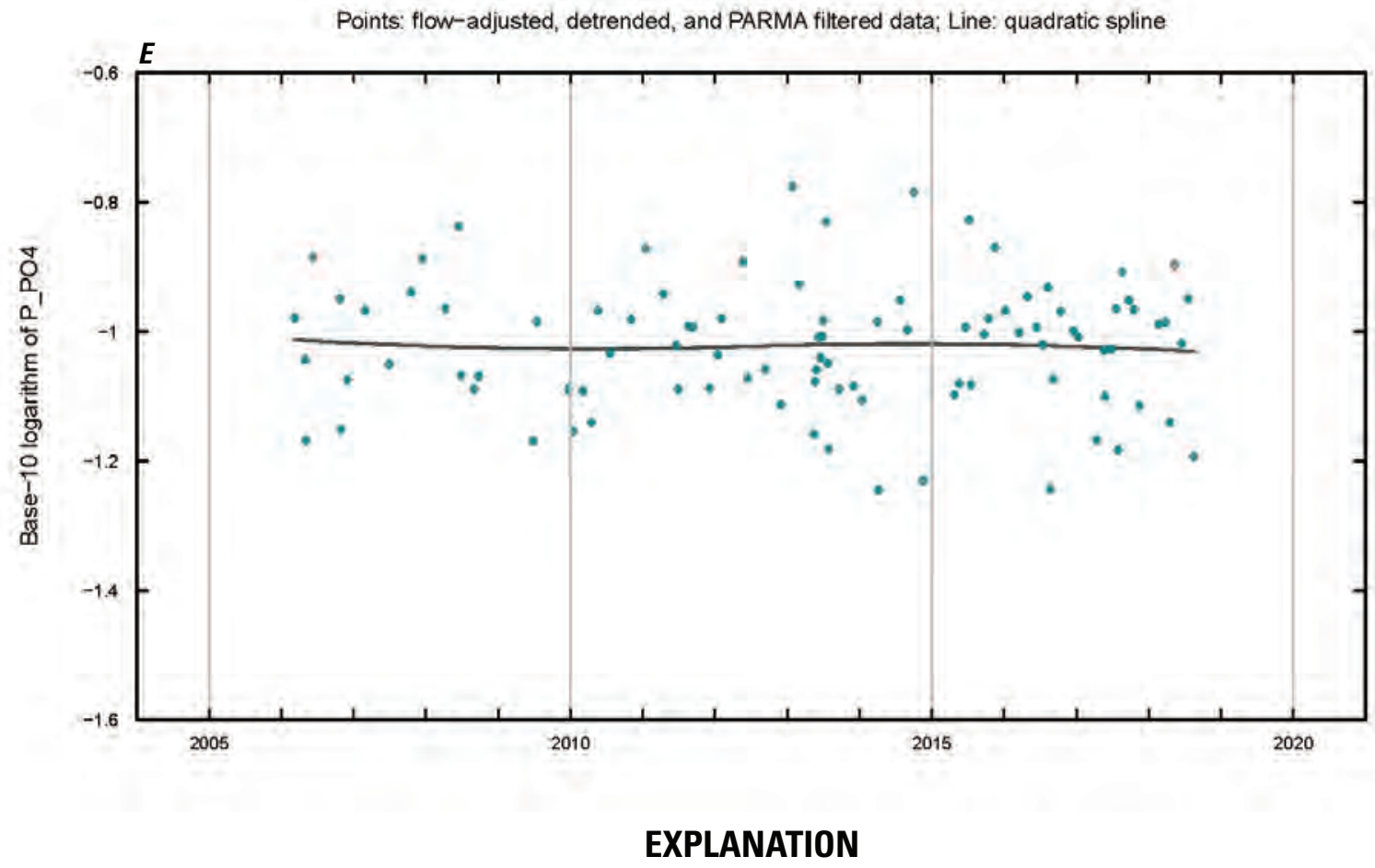

PARMA—Periodic autoregressive moving average

Figure 1.2. Output from runQWmodel for orthophosphate as phosphorus concentration data for the RockQWP dataset (fig. 1.1B) for a single monotonic trend $A$, maximum likelihood estimation results from text file; $B-K$, full graphical output.-Continued 

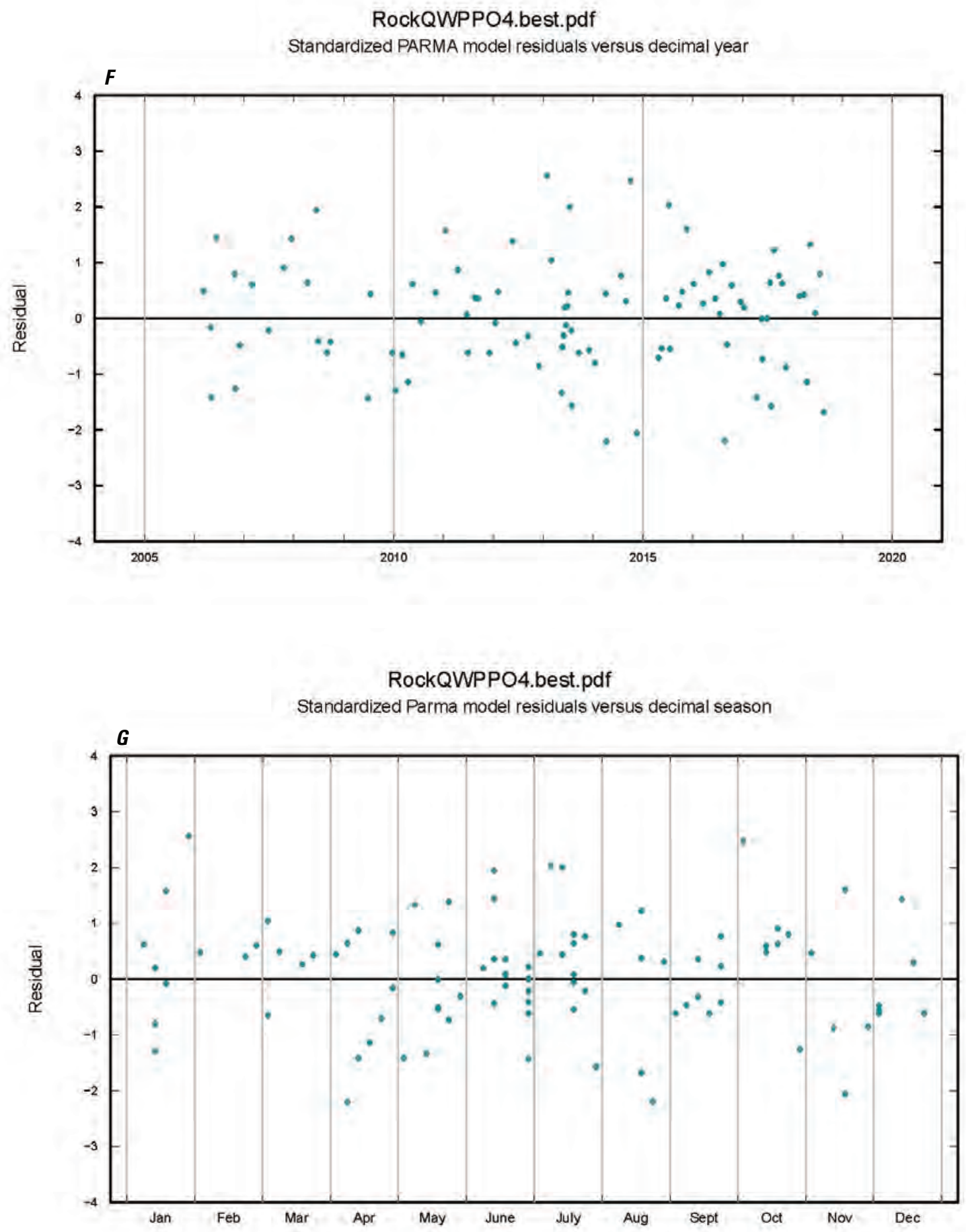

\section{EXPLANATION}

PARMA-Periodic autoregressive moving average

Figure 1.2. Output from run $Q W$ model for orthophosphate as phosphorus concentration data for the RockQWP dataset (fig. 1.1B) for a single monotonic trend $A$, maximum likelihood estimation results from text file; $B-K$, full graphical output.-Continued 

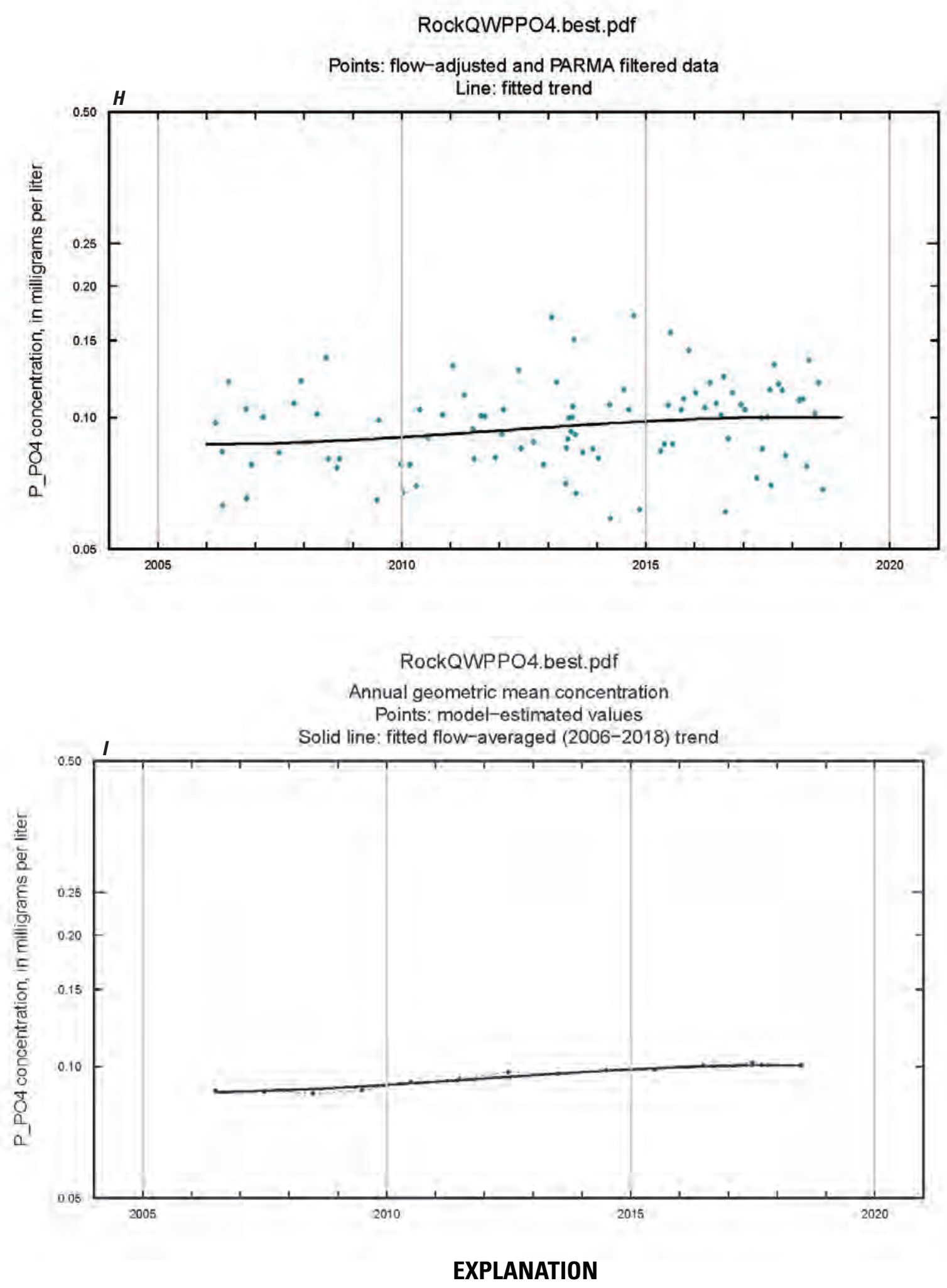

PARMA-Periodic autoregressive moving average

Figure 1.2. Output from run $Q W m o d e l$ for orthophosphate as phosphorus concentration data for the RockQWP dataset (fig. 1.1B) for a single monotonic trend $A$, maximum likelihood estimation results from text file; $B-K$, full graphical output.—Continued 

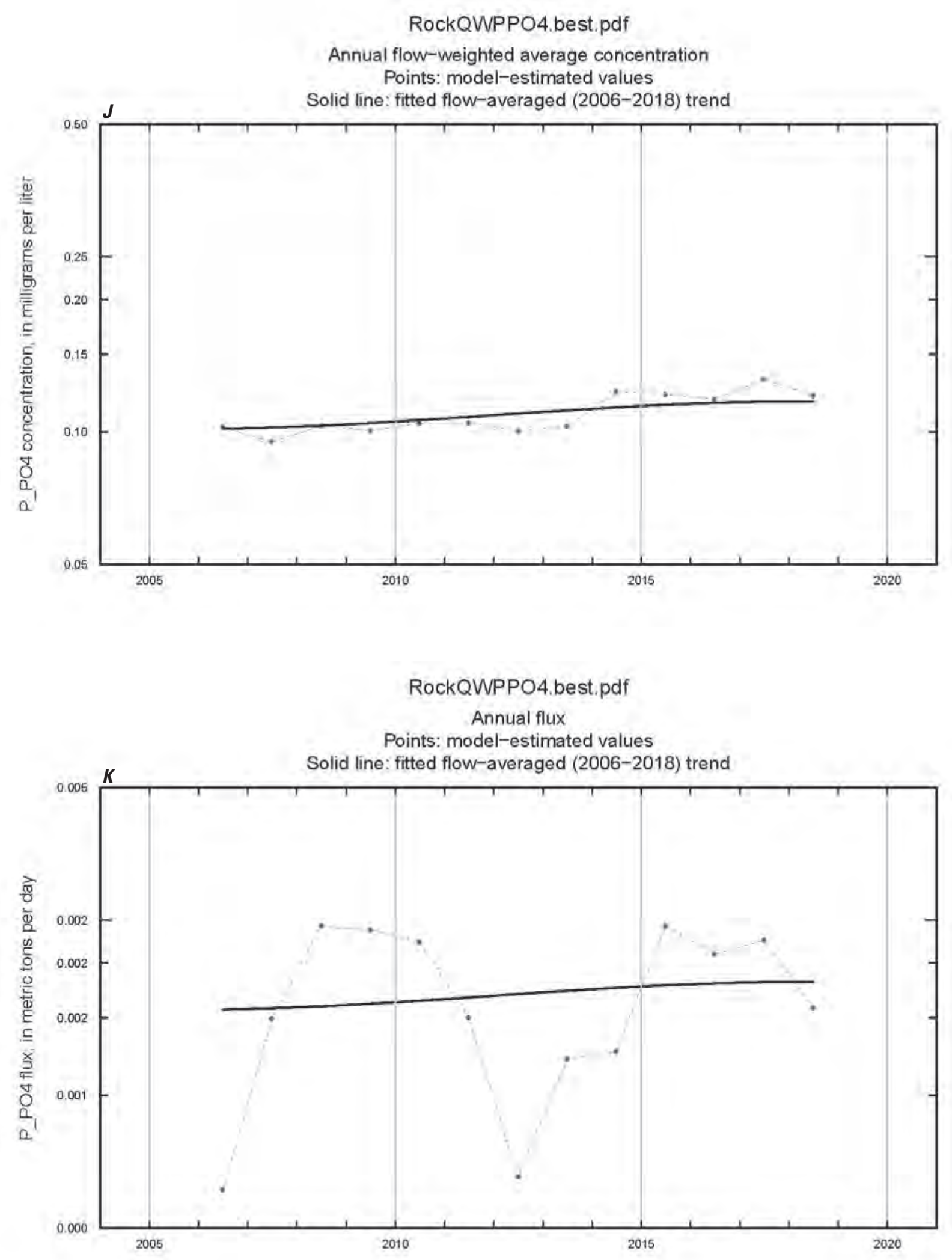

Figure 1.2. Output from run $Q W$ model for orthophosphate as phosphorus concentration data for the RockQWP dataset (fig. 1.1B) for a single monotonic trend $A$, maximum likelihood estimation results from text file; $B-K$, full graphical output.-Continued 


\section{References Cited}

R Development Core Team, 2019, R-A language and environment for statistical computing: Vienna, Austria, R Foundation for Statistical Computing, accessed April 8, 2019, at https://www.r-project.org.
Vecchia, A.V., and Nustad, R.A., 2020, Time-series model, statistical methods, and software documentation for RQWTREND_An R package for analyzing trends in streamwater quality: U.S. Geological Survey Open-File Report 2020-1014, 51 p. [Also available at https://doi.org/10.3133/ ofr20201014.] 


\section{Appendix 2. Estimated Mean Annual Concentration, Load, and Yield for Selected Constituents in Urban Streams in Independence, Missouri}

Mean annual loads of selected nutrients, dissolved chloride, and suspended sediment were estimated for selected urban streams in Independence, Missouri, from January 2006 through December 2018 using the Weighted Regressions on Time, Discharge, and Season-Kalman filter (WRTDS-K) model as described by Zhang and Hirsch (2019), and the data are presented in an Excel spreadsheet (tables 2.1 and 2.2) (available for download at https://doi.org/10/13133/ sir20205130).

\section{References Cited}

Zhang, Q., and Hirsch, R.M., 2019, River water-quality concentration and flux estimation can be improved by accounting for serial correlation through an autoregressive model: Water Resources Research, v. 55, no. 11, p. 97059723, accessed November 2019 at https://doi.org/10.1029/ 2019WR025338. 


\section{Appendix 3. Annual Load Estimates Using Regression and Weighted Regressions on Time, Discharge, and Season-Kalman Filter (WRTDS-K) Models \\ Estimates of annual loads of total nitrogen, total organic nitrogen, dissolved ammonia, and dissolved nitrate plus \\ References Cited} nitrite as nitrogen (table 3.1), total phosphorous, chloride, and suspended sediment (table 3.2) in selected urban streams in Independence, Missouri, were computed for this report using the Weighted Regressions on Time, Discharge, and SeasonKalman filter (WRTDS-K) model (Zang and Hirsch, 2019). In a previous study (Niesen and Christensen, 2015), annual loads of these constituents at the same urban streams were computed using the LOADEST model (Runkel and others, 2004). This appendix contains an Excel spreadsheet (available for download at https://doi.org/10.3133/sir20205130) that compares the results from both studies, as well as the differences between the two models while using the same datasets.
Niesen, S.L., and Christensen, E.D., 2015, Hydrological, water-quality, and ecological data for streams in Independence, Missouri, June 2005 through September 2013: U.S. Geological Survey Data Series 915, 80 p. [Also available at https://doi.org/10.3133/ds915.]

Runkel, R.L., Crawford, C.G., and Cohn, T.A., 2004, Load estimator (LOADEST) - A FORTRAN program for estimating constituent loads in streams and rivers: U.S. Geological Survey Techniques and Methods book 4, chap. A5, 69 p. [Also available at https://doi.org/10.3133/tm4A5https://doi. org/10.3133/tm4A5.]

Zhang, Q., and Hirsch, R.M., 2019, River water-quality concentration and flux estimation can be improved by accounting for serial correlation through an autoregressive model: Water Resources Research, v. 55, no. 11, p. 97059723, accessed November 2019 at https://doi.org/10.1029/ 2019 WR025338. 


\section{Appendix 4. Reclassification of the National Land Cover Database Land Cover in Urban Watersheds in Independence, Missouri}

Land cover information extracted from the National Land Cover Database (NLCD) satellite imagery database was used to determine changes in land use during the period of the study (2005 through 2018). This appendix contains an Excel spreadsheet (available for download at https://doi.org/10.3133/ sir20205130) that lists the 20 classes of coverage used by the NLCD (Yang and others, 2018) and lists the grouping of certain classes used in this report (table 4.1).

\section{References Cited}

\author{
Yang, L., Jin, S., Danielson, P., Homer, C., Gass, L., Bender, \\ S., Case, A., Costello, C., Dewitz, J., Fry, J., Funk, M., \\ Granneman, B., Liknes, G., Rigge, M., and Xian, G., \\ 2018, A new generation of the United States National \\ Land Cover Database - Requirements, research priorities, \\ design, and implementation strategies: ISPRS Journal of \\ Photogrammetry and Remote Sensing, v. 146, p. 108- \\ 123, accessed April 2, 2020, at https://doi.org/10.1016/ \\ j.isprsjprs.2018.09.006.
}

Table 4.1. Reclassification of the National Land Cover Database land cover in urban watersheds in Independence, Missouri.

[Land cover from Yang and others, 2018. NLCD, National Land Cover Database; --, no data]

\begin{tabular}{|c|c|c|c|}
\hline NLCD key & NLCD land cover & Reclassified key & Reclassified land cover \\
\hline 11 & Open water & 11 & Open water \\
\hline 21 & Developed open space & 21 & Developed open space \\
\hline 23 & Developed medium intensity & 23 & Developed medium intensity \\
\hline 24 & Developed high intensity & 24 & Developed high intensity \\
\hline 41 & Deciduous forest & 40 & Forest \\
\hline 42 & Evergreen forest & 40 & Forest \\
\hline 43 & Mixed forest & 40 & Forest \\
\hline 51 & Dwarf scrub & 50 & Grassland \\
\hline 52 & Shrub/scrub & 50 & Grassland \\
\hline 90 & Woody wetlands & 90 & Wetlands \\
\hline 95 & Emergent herbaceous wetlands & 90 & Wetlands \\
\hline 12 & Perennial ice/snow & -- & Land cover was not present and was not used \\
\hline 72 & Sedge/herbaceous & -- & Land cover was not present and was not used \\
\hline 73 & Lichens & -- & Land cover was not present and was not used \\
\hline 74 & Moss & -- & Land cover was not present and was not used \\
\hline
\end{tabular}



For more information about this publication, contact: Director, USGS Central Midwest Water Science Center 1400 Independence Road

Rolla, M0 65401

573-308-3667

For additional information, visit: https://www.usgs.gov/ centers/cm-water

Publishing support provided by the

Rolla Publishing Service Center 


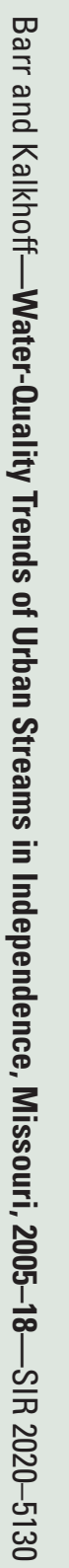

